\title{
A CONFIDENCIALIDADE DA ARBITRAGEM EM COMPANHIAS ABERTAS NO BRASIL
}

Dissertação de Mestrado

Orientador: Professor Doutor José Alexandre Tavares Guerreiro

UNIVERSIDADE DE SÃO PAULO

FACULDADE DE DIREITO

São Paulo - SP

2019 
Dissertação apresentada à Banca Examinadora do Programa de PósGraduação em Direito, da Faculdade de Direito da Universidade de São Paulo, como exigência parcial para obtenção do título de Mestre em Direito, na área de concentração de Direito Comercial, sob a orientação do Professor Doutor José Alexandre Tavares Guerreiro.

UNIVERSIDADE DE SÃO PAULO

FACULDADE DE DIREITO

São Paulo - SP 


\section{Catalogação na Publicação}

\section{Serviço de Processos Técnicos da Biblioteca da}

Faculdade de Direito da Universidade de São Paulo

Vilela, Amanda Cristina Siqueira da Costa

A confidencialidade da arbitragem em companhias abertas no Brasil / Amanda Cristina Siqueira da Costa Vilela. -- São Paulo, 2019. 209 p. ; $30 \mathrm{~cm}$.

Dissertação (Mestrado) - Programa de Pós-Graduação em Direito, Faculdade de Direito, Universidade de São Paulo, São Paulo, 2019. Orientador: José Alexandre Tavares Guerreiro.

1. Companhia aberta. 2. Arbitragem. 3. Confidencialidade. 4. Informação. 5. Governança. I. Guerreiro, José Alexandre Tavares, orient. II. Título. 


\section{A CONFIDENCIALIDADE DA ARBITRAGEM EM COMPANHIAS ABERTAS NO BRASIL}

Dissertação apresentada à Banca Examinadora do Programa de Pós-Graduação em Direito, da Faculdade de Direito da Universidade de São Paulo, como exigência parcial para obtenção do título de Mestre em Direito.

Ata n. / 2019.

Aprovada em de 2019.

Banca Examinadora

Orientador: Professor Doutor José Alexandre Tavares Guerreiro Universidade de São Paulo - USP

Examinador(a)

Examinador(a)

Examinador(a) 
Aos meus pais, por tudo que me ensinaram. Ao Thiago, pelo amor, incentivo e companheirismo. 


\section{AGRADECIMENTOS}

Já haviam me contado que a pesquisa acadêmica é um trabalho extremamente solitário e eu pude comprovar que, de certo modo, isto é verdade. No entanto, são tantas pessoas que se fazem presentes ao longo da caminhada de tantas formas diferentes que essa solidão é suavizada é dá espaço a um sentimento infinito de gratidão a todos que me apoiaram e viveram este projeto ao meu lado.

Agradeço primeiramente ao Professor José Alexandre Tavares Guerreiro, pelo privilégio de tê-lo como orientador desde a Tese de Láurea apresentada à FDUSP em 2014. Agradeço especialmente por ter aceitado a orientação deste trabalho, pelas diversas horas de riquíssimas discussões e pela oportunidade de aprender com o seu brilhantismo e genialidade.

Aos professores Rodrigo Octávio Broglia Mendes e Viviane Muller Prado, pelas valiosas contribuições à pesquisa realizadas durante o exame de qualificação.

À Câmara de Mediação, Conciliação e Arbitragem de São Paulo - CIESP/FIESP, nas pessoas de Lenora Hage e Daniel Falci Goulart, pela atenção e disponibilização de informações que enriqueceram a pesquisa, e ao Centro de Arbitragem da Câmara de Comércio Brasil-Canadá, nas pessoas de Maísa da Silva Barboza e Clara Bastos, pela contribuição com dados para o trabalho.

Ao meu chefe Mauro Cesar Leschziner, pelo incentivo, pela compreensão e pelo tempo que pude dedicar exclusivamente a esta dissertação. Agradeço ainda a toda equipe do Machado Meyer Sendacz e Opice, que muito me apoiou e com quem tenho a alegria de trabalhar e de dividir os desafios do dia-a-dia, Diana Pacifico Henne, Isabela Cruz Sanchez, Lais Silveira de Deus Lopes e também Ana Flávia de Oliveira Britto.

Aos colegas e amigos que dedicaram o seu tempo para discutir o presente trabalho comigo, em especial, à Ana Carolina Devito Dearo Zanetti, pelos inúmeros momentos de vivência acadêmica e pela querida amizade; ao Antonio Alberto de Rondina Cury, amigo desde o início da graduação, pela paciência e pela generosidade em não poupar esforços para ajudar em diversas fases do trabalho; ao Rafael Bresciani, pela disponibilidade e atenção em debater o tema da pesquisa. Agradeço ainda à Lia Yokomizo, pela amizade e parceria durante 
a elaboração desta tese, em especial, no período de finalização; e à Julia Corrêa, pela amizade e pelos incentivos recíprocos que tornaram os últimos anos um pouco mais leves.

Aos amigos que estiveram próximos durante este tempo, suportaram diversas ausências e se fizeram presentes de alguma forma, Alina Miyake, Bruna Nunes, Camilla Garcia Pinetti, Daniela Valente Junqueira Ayres, Layla Sassaki, Guilherme Mazzafera e Silva Vilhena, Mayara Alves, Ricardo de Castro Barbosa e Passos e Saulo Christensen. E também aos amigos que, mesmo mais distantes geograficamente, acompanharam esta trajetória e não pouparam palavras de motivação, Ana Emília Chiaradia, Cristiane Cabral Costa Vilela, Pedro Augusto Schreier Rodrigues e Sofia Schreier Rodrigues.

À Larissa Lafuente Dahyr, pelo amor de irmã, pela disponibilidade em ouvir as minhas ideias e pelo amparo em todos os momentos.

À minha família e, em especial, à minha avó Sahara Vilhena Siqueira, ao meu avô Jaime Lopes Siqueira (in memoriam) e à Maria Augusta Vilhena, pelos exemplos de fé e pelas incansáveis orações.

Aos meus pais Dirceu Xavier da Costa e Celina Aparecida Siqueira da Costa, pelo apoio incondicional e por uma vida repleta de ensinamentos, incluindo, sobretudo, valor do trabalho honesto e a importância do estudo e da dedicação.

Ao Thiago Scudeler Vilela, meu marido e companheiro de todas as horas, agradeço pela parceria na vida e ao longo desta jornada, em especial, pelo amor infinito, pela paciência sem limites e pelo encorajamento constante.

Agradeço, por fim, a Deus por colocar todas essas pessoas no meu caminho e por permitir que tudo isso fosse possível.

A todos, muito obrigada. 


\section{RESUMO}

Amanda Cristina Siqueira da Costa Vilela. A confidencialidade da arbitragem em companhias abertas no Brasil. 209 f. Dissertação de Mestrado. Faculdade de Direito, Universidade de São Paulo, São Paulo, 2017.

Considerando a importância da informação para a manutenção e o funcionamento do mercado de valores mobiliários, bem como para o exercício dos direitos decorrentes da condição de acionista, a opção legislativa no país, seguindo o modelo norte-americano, foi a de instituir, em nossa estrutura societária, um sistema de full disclosure; o qual, dentre outras finalidades, busca melhorar a fiscalização dos órgãos da administração e reduzir custos de agência. Nas companhias abertas, a crescente expansão da arbitragem como meio de solução de litígios decorrentes da cláusula compromissória estatutária teve como consequência natural a redução do nível de informações divulgado aos acionistas e ao mercado sobre as disputas solucionadas por tal método. Por meio do estudo dos fundamentos que justificaram a regulação sobre a divulgação de informações e as normas aplicáveis às companhias abertas brasileiras, procurou-se identificar a suficiência do regime em relação à divulgação sobre procedimentos arbitrais para fins de assegurar a adequada tutela dos interesses dos acionistas, das companhias e do público investidor. Assim, na primeira parte da dissertação, é feita uma revisão das justificativas sobre a regulação da informação no mercado e das normas às quais as companhias abertas estão sujeitas, de acordo com o direito brasileiro. Na segunda parte, é explorada a relação entre arbitragem e confidencialidade e os principais questionamentos ao uso da arbitragem sigilosa por companhias abertas. Por fim, são apresentadas sugestões regulatórias para mitigar as incertezas quanto à utilização da arbitragem estatutária.

Palavras-chave: companhia aberta, arbitragem, confidencialidade, informação, governança. 


\begin{abstract}
Amanda Cristina Siqueira da Costa Vilela. The confidentiality of arbitration in publicly-held companies in Brazil. 209 p. Master Thesis. Faculty of Law, University of São Paulo, São Paulo, 2019

Considering the relevance of information for the running and upkeeping of the securities market, as well as for the exercise of shareholders' rights, the Brazilian legislative approach, inspired by the American model, was a system based on full disclosure; which, among other goals, seeks to improve the monitoring of managers and to reduce agency costs. In publiclyheld companies, the growing expansion of arbitration as a conflict resolution mechanism for disputes arising from the statutory arbitration clauses resulted in the reduction of information disclosed to the shareholders and the market with respect to such disputes. By reviewing the grounds that motivated the regulation over information disclosure in the securities market and the rules applicable to Brazilian publicly-held companies, the sufficiency of the disclosure rules with respect to arbitration proceedings was analyzed in order to confirm whether they provide adequate protection to the interests of shareholders, companies and investors. Thus, in the first part of this master thesis, there is a review on the main reasons for disclosure regulation and of the Brazilian rules on this matter. In the second part, the relation between confidentiality and arbitration is explored, as well as the main inquiries related to the confidential arbitration. Finally, there are propositions on regulatory solutions in order to mitigate the uncertainties related to the statutory arbitration.
\end{abstract}

Key words: publicly-held company, arbitration, confidentiality, information, governance. 


\section{ABREVIATURAS E DEFINIÇÕES}

$\S / \S \S$

B3

CAM

CAM-CCBC

CAM-CIESP/FIESP

CAM-FGV

CAMARB

CBAR

CMN

Código Civil

Código de Processo

Civil de 1973

Constituição Federal

Coord./coords.

CVM

Des.

Ed./Eds.

FIESP

IBGC

ICC

ICVM 31

ICVM 358
Parágrafo/parágrafos.

B3 S.A. - Brasil, Bolsa, Balcão.

Câmara de Arbitragem do Mercado da B3 - Brasil, Bolsa, Balcão.

Centro de Arbitragem da Câmara de Comércio BrasilCanadá.

Câmara de Mediação, Conciliação e Arbitragem de São Paulo - CIESP/FIESP.

Câmara de Arbitragem da Fundação Getúlio Vargas.

Câmara de Mediação e Arbitragem Empresarial- Brasil.

Comitê Brasileiro de Arbitragem.

Conselho Monetário Nacional.

Lei ${ }^{\circ} 10.202$, de 10 de janeiro de 2002, conforme alterada.

Lei ${ }^{\circ} 5.869$, de 11 de janeiro de 1973 , conforme alterada.

Constituição da República Federativa do Brasil de 1988.

Coordenador/coordenadores.

Comissão de Valores Mobiliários.

Desembargador(a).

Editor/editores.

Federação das Indústrias do Estado de São Paulo.

Instituto Brasileiro de Governança Corporativa.

International Chamber of Commerce (Corte Internacional de Arbitragem).

Instrução CVM no 31, de 8 de fevereiro de 1984, revogada pela ICVM 358.

Instrução CVM no 358 , de 3 de janeiro de 2002, conforme alterada pelas instruções CVM no 369/02, 449/07, 547/14, $552 / 14,568 / 15$ e 590/17. 
Instrução CVM n 400, de 29 de dezembro de 2003, conforme alterada pelas instruções CVM n 429/06, 442/06,

ICVM 400 472/08, 482/10, 488/10, 507/11, 525/12, 528/12, 531/13, 533/13, 546/14, 548/14, 551/14, 566/15, 571/15, 583/16, $584 / 17,588 / 17,595 / 18,600 / 18,601 / 18$ e 604/18.

Instrução CVM n 480, de 7 dezembro de 2009, conforme

ICVM 480 alterada pelas instruções CVM no 488/10, 509/11, 511/11, 520/12, 525/12, 547/14, 552/14, 561/15, 567/15, 568/15, 569/15, 583/16, 584/17, 585/17, 586/17, 588/17, 595/18, $596 / 18,600 / 18$ e 604/18.

Instrução CVM n 481, de 17 dezembro de 2009, conforme ICVM 481 alterada pelas instruções CVM no 552/14, 561/15, 565/15, $567 / 15$ e $594 / 17$.

IOSCO

Organização Internacional das Comissões de Valores (International Organization of Securities Commission).

Lei das S.A. Lei ${ }^{\circ} 6.404$, de 15 de dezembro de 1976, conforme alterada.

Lei de Arbitragem Lei $n^{\circ} 9.307$, de 23 de setembro de 1996, conforme alterada.

Lei de Recuperação Judicial e Falência Lei $\mathrm{n}^{\circ} 11.101$, de 9 de fevereiro de 2005, conforme alterada.

Lei do Mercado de

Valores Mobiliários

Lei ${ }^{\circ}$ 6.385, de 7 de dezembro de 1976, conforme alterada.

Novo Código de

Processo Civil

Lei ${ }^{\circ} 13.105$, de 16 de março de 2015, conforme alterada.

NYSE

New York Stock Exchange (Bolsa de Valores de Nova Iorque).

Organisation for Economic Co-operation and Development

OECD (Organização para a Cooperação e Desenvolvimento Econômico).

Org./Orgs. Organizador/organizadores.

p./pp. Página/páginas.

Rel. Relator(a).

SEC Securities Exchange Commission. Superintendência de Relação com Empresas. 
SS.

STF

TJRJ

TJSP
Seguintes.

Supremo Tribunal Federal.

Tribunal de Justiça do Estado do Rio de Janeiro.

Tribunal de Justiça do Estado de São Paulo. 


\section{SUMÁRIO}

INTRODUÇÃO. .15

a. Delimitação do escopo ................................................................................15

b. Consideraçõoes históricas iniciais ......................................................................................... 19

c. Plano de trabalho.............................................................................................................37

PARTE I - O REGIME DE DIVULGAÇÃO DE INFORMAÇÕES ............................. 38

CAPÍTULO 1 - OS FUNDAMENTOS DA REGULAÇÃO SOBRE DIVULGAÇÃO OBRIGATÓRIA DE INFORMAÇÕES PELAS COMPANHIAS

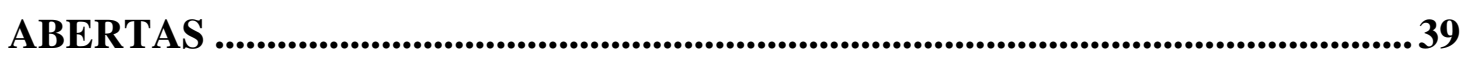

1.1 Aspectos históricos do regime de divulgação obrigatória de informações ........ 39

1.2 As justificativas para o regime de divulgação obrigatória de informações ....... 47

1.2.1 A busca por informação …...................................................................... 47

1.2.2 A correção da falha de mercado: informação como bem público...............49

1.2.3 Redução de custos de agência e impactos na governança..........................51

1.2.4 Combate à fraude, proteção ao investidor e outras justificativas................58

1.3 Questionamentos ao regime de divulgação obrigatória de informações ........... 61

1.3.1 Os incentivos à divulgação voluntária de informações.............................61

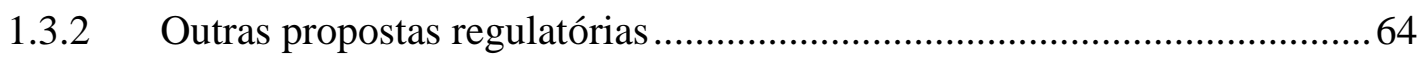

1.3.2 As dúvidas sobre a escolha racional e a decisão do investidor ..................68

CAPÍTULO 2 - O REGIME DE DIVULGAÇÃO DE INFORMAÇÕES OBRIGATÓRIO APLICÁVEL ÀS COMPANHIAS ABERTAS NO BRASIL .. 75

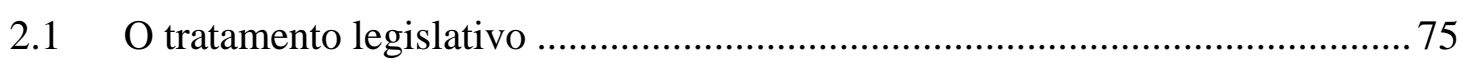

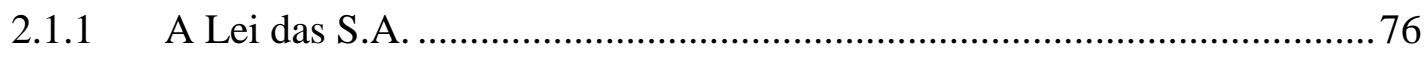

a. Informações decorrentes da condição de acionista ...................................... 76

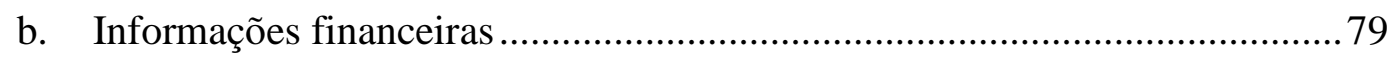

c. Obrigação de informar dos administradores .............................................. 80

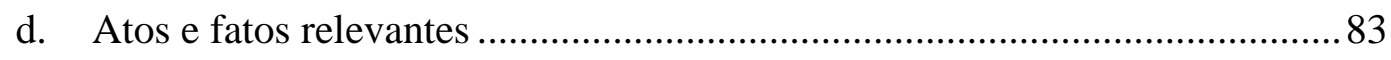

2.1.2 A Lei do Mercado de Valores Mobiliários ............................................... 85

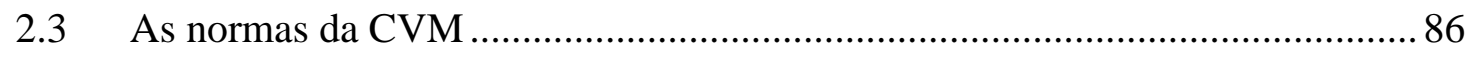

2.3.1 A ICVM 480 e o Formulário de Referência................................................. 86

2.3.2 A ICVM 358 e os Fatos Relevantes ....................................................... 93

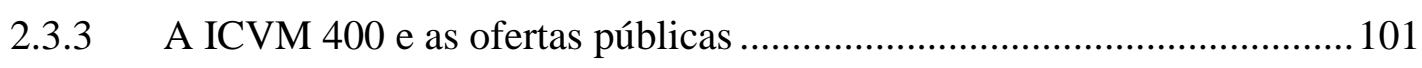


2.4 Ponderações sobre a divulgação mandatória de informações ........................... 103

PARTE II - INFORMAÇÃO, ARBITRAGEM E COMPANHIAS ABERTAS........ 106

CAPÍTULO 3 - A RELAÇÃO ENTRE CONFIDENCIALIDADE E ARBITRAGEM ..................................................................................................... 108

3.1 A confidencialidade na arbitragem comercial internacional ......................... 110

3.2 O tratamento da confidencialidade na arbitragem no Brasil .......................... 116

3.3 Relativizações à confidencialidade na arbitragem......................................... 121

3.3.1 Arbitragem na administração pública ....................................................122

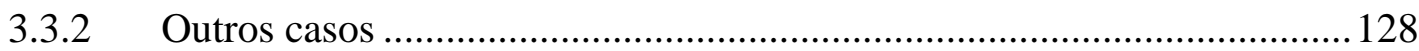

CAPÍTULO 4 - A ARBITRAGEM E O DIREITO SOCIETÁRIO......................131

4.1 Questionamentos à confidencialidade de arbitragens societárias .................... 133

4.1.1 O direito de fiscalização e de voto do acionista ...................................... 140

4.1.2 O direito do mercado à informação......................................................... 146

4.1.3 A falta de jurisprudência arbitral.......................................................... 148

4.1.4 Desdobramentos processuais: litisconsórcio e efeitos da coisa julgada... 152

4.2 Propostas de regulação sobre a confidencialidade. ....................................... 155

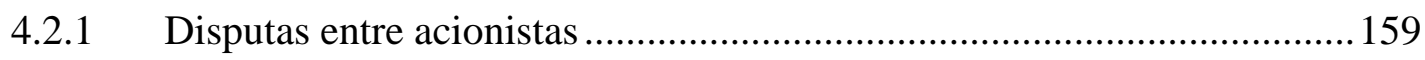

4.2.2 Disputas entre acionistas e administradores ......................................... 160

4.2.3 Disputas entre acionistas e a companhia ................................................ 163

4.2.4 Disputas entre administradores e a companhia ..................................... 164

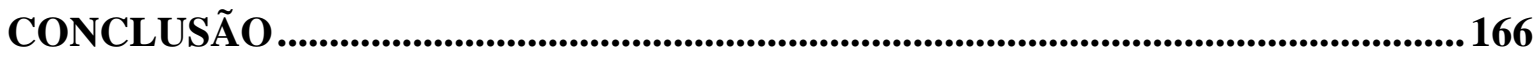

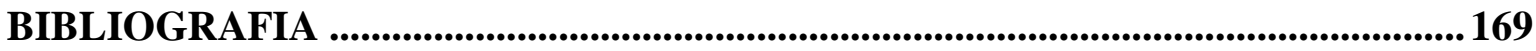

a. Livros e Artigos ........................................................................................................... 169

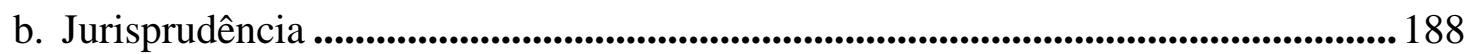

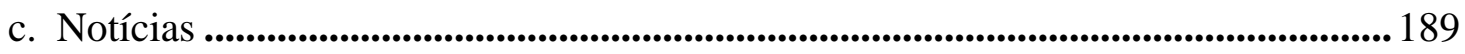

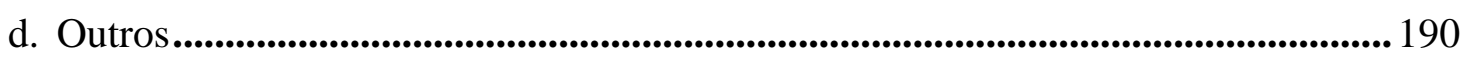

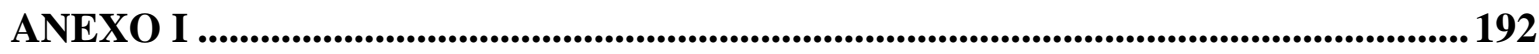




\section{INTRODUÇÃO}

\section{a. DELIMITAÇ̃̃o DO ESCOPO}

A existência de disputas faz parte das relações entre sócios e com a sociedade. A solução rápida e eficaz desses litígios, por outro lado, é essencial para o funcionamento eficiente da companhia, sem perda de produtividade ou oportunidades de negócio e com o menor impacto possível no preço dos valores mobiliários emitidos, em especial suas ações ${ }^{1}$. A arbitragem é uma forma de solução de conflitos que tem a pretensão de fornecer decisões com maior celeridade, tecnicidade e sofisticação, resguardada a confidencialidade em relação ao procedimento ${ }^{2}$. Outras vantagens são relacionadas à flexibilidade e informalidade

\footnotetext{
${ }^{1}$ MARTINS, Pedro Batista. Arbitragem no Direito Societário. São Paulo: Quartier Latin, 2012, p. 114.

${ }^{2}$ Sobre as vantagens comumente atribuídas à arbitragem: CARREIRA ALVIM, J. E., Tratado Geral da Arbitragem Interno. Belo Horizonte: Mandamentos, 2000, p. 77, "Se se pudesse apontar como única vantagem da arbitragem a possibilidade de julgamento do litígio exatamente no prazo estabelecido pelas partes, essa instituição já estaria plenamente justificada, num país onde a Justiça estatal não tem respondido, com eficiência, às angústias dos jurisdicionados"; CAHALI, Francisco José. Curso de Arbitragem. São Paulo: Revista dos Tribunais, 2011, pp. 75-77; PUGLIESE, Antonio Celso Fonseca; SALAMA, Bruno Meyerhof. "A Economia da Arbitragem: Escolha Racional e Geração de Valor”. Revista Direito GV, vol. 4, $\mathrm{n}^{\circ}$ 1, São Paulo, 2008, p. 024, “A arbitragem permite redução dos custos de transação em virtude, principalmente, (a) da agilidade com que é concluída, (b) da especialização dos árbitros e (c) da imparcialidade do árbitro, especialmente nos casos de arbitragens internacionais. A maior eficiência da arbitragem na solução de disputas cria incentivos para o adimplemento das obrigações contratuais pelas partes"; GUILHERME, Luiz Fernando do Vale de Almeida. "As Novas Formas de Atuação do Advogado no Mundo Globalizado Empresarial - A Arbitragem no Mercado de Capitais”. In: VERÇOSA, Haroldo Malheiros Duclerc (org.). Aspectos da Arbitragem Institucional: 12 Anos da Lei 9.307/1996. São Paulo: Malheiros, 1998, p. 123; TELLECHEA, Rodrigo. "Sobre a cláusula arbitral em companhias abertas: a questão da confidencialidade do procedimento". In: FRANÇA, Erasmo Valladão Azevedo e Novaes (coord.). Direito Societário Contemporâneo II. São Paulo: Malheiros, 2015, p. 578. Outra vantagem apontada da arbitragem diz respeito à sua função menos litigiosa em especial entre partes com relações de longo prazo, o que pode ser o caso de disputas societárias. Neste sentido, BRACKER, Julie K., SODERQUIST, Larry D. “Arbitration in the Corporate Context". Columbia Business Law Review, $\mathrm{n}^{\circ}$ 1, 2003, p. 2, "Those involved in corporations easily perceive the efficiency and cost advantages in arbitration over litigation. Efficiency is gained through informality of procedural and evidentiary rules, as well as limited discovery. (...) Arbitration can be particularly effective when the parties have an ongoing relationship, as it avoids the entrenchment created by the adversarial stance of protracted litigation". Não obstante as reconhecidas vantagens da arbitragem, cumpre lembrar que se trata de um método de solução de controvérsias destinado a determinado grupo de litígios, não sendo a melhor alternativa para todos os casos de forma indiscriminada; neste sentido, CARMONA, Carlos Alberto. "Arbitragem e Jurisdição". Revista de Processo, vol. 58, 1990, "A arbitragem não tem o condão de aliviar o acúmulo de trabalho de nosso Poder Judiciário. Não é verdade que a arbitragem seja um meio rápido, secreto e barato de resolver qualquer controvérsia: a arbitragem pode ser bastante demorada em causas complexas e que exijam produção de prova pericial;"; CARMONA, Carlos Alberto. "Em torno do árbitro". Revista Internacional de Arbitragem e Conciliação, ano III, 2010, p. 8, "Mas também é verdade que os contendentes não escolhem a arbitragem para poder fugir deste horror, e sim porque querem um método diferente de julgar, mais arejado, mais técnico, menos burocrático. Se é verdade inconteste que o Poder
} 
do procedimento e a maior fluidez do processo $^{3}$, sendo a arbitragem considerada a melhor forma para resolver litígios societários ou ao menos, melhor se comparada com o processo judicial ${ }^{4-5}$.

A inserção de cláusula compromissória no estatuto social pode ser aprovada por acionistas de sociedades anônimas abertas ou fechadas (e também por sócios de sociedades limitadas), conforme previsão do artigo $109, \S^{\circ}$ da Lei das S.A.

Fizemos um levantamento, dentre as companhias abertas listadas na B3, e verificamos que do total de 396 (trezentas e noventa e seis) companhias listadas, 236 (duzentas e trinta e seis) possuem cláusula compromissória estatutária, o que representa aproximadamente $60 \%$ (sessenta por cento) do total de companhias listadas, das quais (i) cerca de $75 \%$ (setenta e cinco por cento) têm a cláusula compromissória obrigatória em virtude da aplicação dos regulamentos de listagem aos quais estão sujeitas, isto é, são dos segmentos do Novo Mercado, Nível 2, Bovespa Mais e Bovespa Mais Nível 2, incluindo a indicação da CAM como entidade aplicável para administração dos conflitos; e (ii) aproximadamente $25 \%$ (vinte e cinco por cento) representando companhias dos segmentos Tradicional e Nível 1 aderiram à arbitragem independentemente do regulamento de listagem ${ }^{6}$.

Judiciário tem sérias dificuldades no Brasil, também é fato sabido que em países desenvolvidos, nos quais o Judiciário anda muito bem, a arbitragem desenvolve-se à larga".

${ }^{3}$ GU WEIXIA. "Securities Arbitration in China: A Better Alternative to Retail Shareholder Protection". Northwestern Journal of International Law \& Business, vol. 33, issue 2, 2013, pp. 305-308.

${ }^{4}$ LEVY, Daniel de Andrade. "Aspectos Polêmicos da Arbitragem no Mercado de Capitais". Revista Brasileira de Arbitragem, vol. 7, issue 27, 2010, pp. 7-37; FRIAS, Angélica Ramos de. "Alcance subjetivo da cláusula compromissória na solução de conflitos societários e no âmbito do mercado de capitais". In: PENTEADO, Mauro Rodrigues; MUNHOZ, Eduardo Secchi (coords.). Mercado de capitais brasileiro - doutrina, cases e materials. São Paulo: Quartier Latin, 2012, p. 57; GU WEIXIA. "Securities Arbitration in China: A Better Alternative to Retail Shareholder Protection". Northwestern Journal of International Law \& Business, vol. 33, issue 2, 2013, pp. 305-306; WALD, Arnoldo. "A reforma da Lei das Sociedades Anônimas: os Direitos dos Minoritários na Nova Lei das S.A. In: LOBO, Jorge (coord.). A reforma da Lei das Sociedades Anônimas: Inovações e Questões Controvertidas da Lei 10.303, de 31 de outubro de 2001, $2^{\mathrm{a}} \mathrm{Ed}$. Rio de Janeiro: Forense, 2002, p. 238.

${ }^{5}$ Pesquisa realizada em 2018 pela Queen Mary University of London junto com o White \& Case sobre a evolução da arbitragem internacional identificou que $97 \%$ (noventa e sete por cento) dos participantes indica a arbitragem como seu meio preferido de resolução de disputas "cross border", seja em conjunto com outros métodos alternativos de solução de controvérsias ou isoladamente, vide 2018 International Arbitration Survey: The Evolution of International Arbitration. White \& Case e School of International Arbitration, Queen Mary University of London, 2018. Disponível em <http://www.arbitration.qmul.ac.uk/media/arbitration/docs/2018-International-Arbitration-Survey---TheEvolution-of-International-Arbitration-(2).PDF>, acesso em novembro de 2018.

${ }^{6}$ Para os fins desta pesquisa, consideramos as companhias listadas nos segmentos Bovespa Mais, Bovespa Mais Nível 2, Novo Mercado, Nível 2, Nível 1 e Tradicional junto à B3, conforme tabela disponibilizada no sítio eletrônico da B3 em novembro de 2018. Considerando que os dois últimos (isto é, Nível 1 e Tradicional) são os únicos cujos regulamentos não contêm previsão de adesão obrigatória à arbitragem pela CAM, fizemos a análise dos estatutos de tais companhias a fim de verificar a incidência da adesão espontânea à arbitragem. 
Pesquisa conduzida por Selma Maria Ferreira Lemes ${ }^{7}$ junto ao Centro de Arbitragem da AMCHAM - Brasil, CAM-CCBC, CAM-CIESP/FIESP, CAM, CAM-FGV e CAMARB relativa ao período de janeiro de 2010 a dezembro de 2017 reforça a crescente expansão da arbitragem em litígios societários. Em relação a 2010, o número de procedimentos arbitrais novos em 2017 cresceu 114,84\% (cento e quatorze inteiros e oitenta e quatro centésimos por cento). O aumento também se reflete nos valores envolvidos: em 2010, o total nas câmaras pesquisadas era de $\mathrm{R} \$ 2,8$ bilhões, enquanto em 2017 atingiu mais de $\mathrm{R} \$ 26$ bilhões, o que representa um crescimento de quase 10 vezes. O CAM-CCBC é o centro com o maior número de procedimentos arbitrais ${ }^{8}$, dos quais $42,58 \%$ (quarenta e dois inteiros e cinquenta e oito centésimos por cento) dizem respeito a matéria societária. Já na CAM, 89,47\% (oitenta e nove inteiros e quarenta e sete centésimos por cento) dos procedimentos tratam de matérias societárias.

Além dos benefícios normalmente associados à arbitragem enquanto método de solução de conflitos, a sua adoção pelas companhias abertas é vista como uma boa prática de governança corporativa ${ }^{9}$. Os princípios de governança previstos pela OECD mencionam a arbitragem como uma alternativa eficiente de solução de conflitos ${ }^{10}$. Da mesma forma, o Código de Melhores Práticas de Governança Corporativa do IBGC estabelece que os conflitos societários devem ser resolvidos por negociação e, caso isso não seja possível, por

\footnotetext{
Para tanto, consultamos a última versão do estatuto social disponibilizada no sítio eletrônico da CVM. Em relação ao Nível 1, das 27 (vinte e sete) companhias listadas, 8 (oito) contêm cláusula compromissória estatutária, das quais 7 (sete) preveem a arbitragem pela CAM e uma, a Cia. Energética de Minas Gerais CEMIG, prevê a arbitragem pela CAM ou pela Câmara FGV de Mediação e Arbitragem. Já em relação ao Nível Tradicional, das 190 (cento e noventa) companhias listadas, 49 (quarenta e nove) possuem cláusula compromissória estatutária, das quais (i) 31 (trinta e uma) companhias apontam a CAM como instituição responsável pela condução da arbitragem, (ii) 9 (nove) companhias escolhem o CAM-CCBC, (iii) 5 (cinco) companhias indicam a ICC, (iv) 2 (duas) companhias não indicam a câmara aplicável, e (v) no caso de uma companhia, não foi possível identificar a câmara aplicável, pois há menção a duas instituições distintas, a CAM e a ICC.

${ }^{7}$ LEMES, Selma Maria Ferreira. Arbitragem em Números e Valores - Seis Câmaras - 8 anos - Período de 2010 (jan./dez.) a 2017 (jan./dez.), 2018.

8 Segundo informação publicada pela própria câmara, em dezembro de 2018, existem mais de 320 procedimentos arbitrais ativos, com valor envolvido de aproximadamente $\mathrm{R} \$ 50$ bilhões de reais. Neste sentido, vide: CAM-CCBC administra número recorde de procedimentos. Sítio eletrônico do CAM-CCBC, publicado em 18 de dezembro de 2018. Disponível em <https://ccbc.org.br/cam-ccbc-centro-arbitragemmediacao/noticias-cam-ccbc/novidades-cam-ccbc/noticias-cam/cam-ccbc-recorde-de-procedimentos/>, acesso em dezembro de 2018.

${ }^{9}$ MARTINS, Pedro Batista. Arbitragem no Direito Societário. São Paulo: Quartier Latin, 2012, p. 115.

${ }^{10}$ Item II, p. 19, OECD, G20/OECD Principles of Corporate Governance, OECD Publishing: Paris, 2015. Disponível em <http://dx.doi.org/10.1787/9789264236882-en>, acesso em julho de 2018, “Many countries have found that alternative adjudication procedures, such as administrative hearings or arbitration procedures organised by the securities regulators or other regulatory bodies, are an efficient method for dispute settlement, at least at the first instance level".
} 
mediação ou arbitragem ${ }^{11}$ e a Cartilha de Governança Corporativa da CVM recomenda a adoção da cláusula compromissória estatutária, destacando a maior celeridade dos processos $\operatorname{arbitrais}^{12}$.

Em decorrência da complexidade das relações jurídicas que se formam nas transações de mercado, uma das normas que mais impacta na decisão de investimento diz respeito à forma mais eficiente de resolução de controvérsias ${ }^{13} \mathrm{e}$, neste sentido, a adoção da arbitragem é associada ao desenvolvimento do mercado.

A extensa adoção e incentivo ao uso da arbitragem societária pelas companhias abertas em decorrência de disposição estatutária teve como consequência natural a redução das informações disponibilizadas aos acionistas e ao mercado em relação aos litígios em andamento, uma vez que a esmagadora maioria dos procedimentos arbitrais é sigilosa, seja por disposição das partes ou por força do regulamento da câmara escolhida.

Para a sociedade e, de modo especial, para companhias abertas, a informação assume um papel de extrema relevância, desde sua função junto ao empresário que precisa desenvolver e conhecer o seu negócio, os seus concorrentes, sua tecnologia, seu plano de desenvolvimento, até o investidor, que busca emissores e títulos mais atrativos para alocar seus recursos de acordo com o seu perfil de risco, e também o acionista que precisa ter ciência dos andamento dos negócios nos quais investiu. Assim, para manter o mercado em funcionamento, informação é essencial ${ }^{14}$. Este é um entendimento tão consolidado, que atraiu a regulação estatal para o tema, exercida por meio de normas específicas obrigando as companhias abertas a se registrarem previamente à realização de emissões e a divulgarem um extenso rol de informações periódicas e eventuais.

\footnotetext{
${ }^{11}$ Item 1.4, Instituto Brasileiro de Governança Corporativa. Código das Melhores Práticas de Governança $\begin{array}{lllllll}\text { Corporativa, } & 5^{\mathrm{a}} \quad \text { Ed. } & \text { São } & \text { Paulo: } & \text { IBGC, } & 2015 . & \text { Disponível }\end{array}$ $<$ http://www.ibgc.org.br/userfiles/files/Publicacoes/Publicacao-IBGCCodigoCodigodasMelhoresPraticasdeGC-5aEdicao.pdf>, acesso em outubro de 2018.

12 Item III.6, CVM. Recomendações da CVM sobre Governança Corporativa, 2002. Disponível em <http://www.cvm.gov.br/export/sites/cvm/decisoes/anexos/0001/3935.pdf>, acesso em outubro de 2018.

${ }_{13}$ MUNHOZ, Eduardo Secchi. "Arbitragem e Novo Mercado". In: MATTOS FILHO; VEIGA FILHO; MARREY JR.; QUIROGA ADVOGADOS (eds.). Arbitragem no Brasil. São Paulo: Impressão Régia, 2010, p. 29; CAMINHA, Uinie. “Arbitragem como Instrumento de Desenvolvimento do Mercado de Capitais”. In: VERÇOSA, Haroldo Malheiros Duclerc (org.). Aspectos da arbitragem institucional: 12 anos da Lei 9.307/1996. São Paulo: Malheiros, 2008, p. 95.

${ }^{14}$ PROENÇA, José Marcelo Martins. Regime Jurídico do Uso de Informações Privilegiadas no Mercado de Capitais - Insider Trading. Tese de Doutorado. Faculdade de Direito da Universidade de São Paulo, 2004, p. 87, "o cuidado de informar corretamente por um lado, e por outro, de pesquisar todas as informações disponíveis e ainda conferi-las, não é importante apenas para o mercado de capitais, consistindo em preocupação inerente a toda a atividade econômica, alcançando, logicamente, os investidores".
} 
Por meio da presente pesquisa, pretende-se analisar os efeitos da redução informacional ocasionada pela expansão da adoção da arbitragem, à luz da regulação de divulgação mandatória de informações à qual as companhias abertas estão sujeitas, da função desempenhada pela informação no mercado e das eventuais consequências para acionistas, investidores e o mercado.

Diante da necessidade de limitação do tema, as considerações do presente trabalho serão restritas aos efeitos da convenção de arbitragem constante do estatuto social de companhias abertas brasileiras, conforme permissão expressa do artigo $109, \S^{\circ}$ da Lei das S.A. ${ }^{15}$. O objetivo da delimitação proposta foi restringir a análise aos conflitos internos à companhia, isto é, entre a companhia, seus acionistas, administradores e membros do conselho fiscal, que tratarão naturalmente de matérias atinentes às relações criadas em decorrência das posições ocupadas perante a sociedade.

\section{b. CONSIDERAÇÕES HISTÓRICAS INICIAIS}

O uso da arbitragem como forma de resolução de disputas no Brasil, em especial de disputas societárias, é previsto desde a época colonial ${ }^{16}$, mas sua efetiva utilização e aceitação demorou para ocorrer no país ${ }^{17}$. No Brasil imperial, a constituição de $1824^{18}$ já previa essa forma de jurisdição e, posteriormente, o Código Comercial de 1850 determinou

\footnotetext{
${ }^{15}$ Por essa razão a dissertação não aborda os efeitos das demais convenções de arbitragem celebradas pelos acionistas e pela companhia com terceiros, como por exemplo, em contratos com fornecedores, clientes, prestadores de serviços ou em contratos de operações de reorganização societária. Não obstante, conforme será mais discutido na Parte II, muitas das considerações aqui apresentadas em relação aos litígios decorrentes de cláusula compromissória estatutária se aplicam às demais arbitragens envolvendo companhias abertas.

${ }^{16} \mathrm{Na}$ época colonial, a previsão da arbitragem já constava desde as ordenações Afonsinas, Manuelinas e, de modo especial Filipinas, em que havia a previsão dos chamados “juízes arbitrais”.

${ }^{17}$ STRAUBE, Frederico José. “A evolução da arbitragem no Brasil após a Lei 9307/1996”. Revista de Arbitragem e Mediação, vol. 50, 2016, pp. 177-183, "Não obstante, como se constata, albergada desde cedo em nosso quadro institucional, a arbitragem muito demorou a contar com a aceitação da comunidade e dos operadores do direito, como alternativa válida para a solução de conflitos. Pode-se dizer, com segurança, que nem a evolução do instituto no exterior nem também o desenvolvimento paulatino, mas constantes das relações financeiras e comerciais internacionais, tiveram o condão de disseminar a prática e a cultura arbitral em nosso país". Sobre o histórico da arbitragem no país, VILELA, Marcelo Dias Gonçalves. Arbitragem no Direito Societário. Belo Horizonte: Mandamentos, 2004, pp. 46 e ss.

18 A primeira constituição do país previa um governo monárquico e hereditário, criou o chamado Poder Moderador, exercido exclusivamente pelo imperador (em adição aos poderes Executivo - também exercido pelo imperador, Legislativo e Judiciário), estabeleceu o voto censitário, e tratou especificamente da arbitragem em seu capitulo sobre Juízes e Tribunais de Justiça, prevendo em seu artigo 160: Nas civeis, e nas penaes civilmente intentadas, poderão as Partes nomear Juizes Arbitros. Suas Sentenças serão executadas sem recurso, se assim o convencionarem as mesmas Partes.
} 
que disputas entre sócios, durante a sociedade ou em sua liquidação, seriam obrigatoriamente resolvidas por arbitragem ${ }^{19}$, tornando, portanto, o juízo arbitral necessário e obrigatório. O Decreto 737 também de 1850, diferenciou as hipóteses do uso obrigatório e facultativo da arbitragem, sendo a primeira reservada para causas comerciais e a última para os demais $\operatorname{casos}^{20}$. Com a Lei 1.350 , de 14 de setembro de 1866, foi abolido o juízo arbitral forçado ${ }^{21}$ e, posteriormente, o Decreto 3.900 de 26 de junho de 1867 regulou o juízo arbitral facultativo e, pela primeira vez, estabeleceu que a cláusula compromissória teria natureza de promessa de contratar, prevendo ainda a possibilidade de recurso da decisão arbitral.

Mais tarde, o Código Civil de 1916 e também os Códigos de Processo Civil de 1939 e 1973 determinaram que o laudo arbitral deveria ser homologado pelo juízo competente para se tornar título executivo entre as partes e seus sucessores. Assim como estabelecido no Decreto 3.900, também nesta época, a cláusula compromissória era entendida como um pacto preliminar com a finalidade de celebração do compromisso arbitral. Consequentemente, a cláusula estaria sujeita às regras aplicáveis aos pactos preliminares, incluindo aquela relativa ao seu inadimplemento, que não daria ensejo à execução específica ${ }^{22}$.

Durante esse período, a arbitragem não se mostrou como meio eficiente para a solução de litígios, em decorrência da necessidade de homologação do laudo perante o juízo estatal, em que podia ser analisada até mesmo a justiça da decisão ${ }^{23}$ e também da não

\footnotetext{
${ }^{19}$ O Código Comercial de 1850 trouxe diversos dispositivos tratando sobre a arbitragem como meio de solução das disputas entre os sócios. Como regra geral, o artigo 294 previa: Todas as questões sociais que se suscitarem entre sócios durante a existência da sociedade ou companhia, sua liquidação ou partilha, serão decididas em juízo arbitral. Para tanto, o artigo $302, \S 5^{\circ}$ determinava que o contrato social deveria indicar a forma de nomeação dos árbitros. Ainda, o artigo 348 previa que, finda a liquidação da companhia, o sócio discordante da forma de liquidação e partilha deveria apresentar reclamação em 10 (dez) dias. Caso a discordância apresentada tempestivamente não fosse resolvida entre os interessados, a disputa seria decidida por árbitros. ${ }^{20}$ Artigo 411 do Decreto 737, de 25 de novembro de 1850: O Juizo arbitral ou é voluntario ou necessario: $\S 1^{\circ}$ É voluntario, quando é instituido por compromisso das partes.

$\S 2^{\circ}$ É necessario, nos casos dos arts. 245, 294, 348, 739, 783 e 846 do Codigo Commercial, e em todos os mais, em que esta fórma de Juizo é pelo mesmo Codigo determinada.

${ }^{21}$ Artigo $1^{\circ}$ da Lei 1.350/1866: Fica derogado o Juizo Arbitral necessario, estabelecido pelo artigo vinte titulo unico do Codigo Commercial.

$\S 1^{\circ}$ O Juizo Arbitral será sempre voluntario mediante o compromisso das partes

$\S 2^{\circ}$ Podem as partes autorizar os seus arbitros para julgarem por equidade independentemente das regras e fórmas de direito.

${ }^{22}$ BEVILAQUA, Clovis. Comentários ao Código Civil, vol. 4. São Paulo: Francisco Alves, 1958, p. 154, “A cláusula compromissória, no direito pátrio, cria apenas uma obrigação de fazer. É um pacto preliminar, cujo objeto é a realização de um compromisso. E como obrigação de fazer, desde que 'nemo potest precise cogi ad factum' não obriga às partes a celebração do compromisso, embora o não celebrá-lo constitua infração do contrato, que dará lugar à responsabilidade civil".

${ }^{23}$ BERTOLDI, M. Marcelo. Reforma da Lei das Sociedades Anônimas - Comentários à Lei 10.303 de 31

de outubro de 2001. $2^{\text {a }}$ Ed. São Paulo: Editora Revista dos Tribunais, 2002, p. 78.
} 
exequibilidade da cláusula compromissória arbitral, tendo em vista sua natureza de promessa de contratar. A necessidade de homologação do laudo perante o Poder Judiciário retirava (ou, ao menos, reduzia) as principais vantagens normalmente associadas à arbitragem, isto é, a confidencialidade, o custo (que sofria um acréscimo com os valores relacionados à homologação) e a celeridade ${ }^{24}$. A consequência do tratamento de promessa dispensado à cláusula compromissória era o fato de que o inadimplemento de tal cláusula era resolvido pelos tribunais apenas em perdas e danos ${ }^{25}$. Desta forma, só havia instauração da arbitragem em caso de celebração de compromisso arbitral entre as partes.

Durante a década de 70, o cenário de pouco interesse pela arbitragem começou a se modificar tanto na área acadêmica, quanto na prática. Na Faculdade de Direito da Universidade de São Paulo, professores de direito internacional começaram a divulgar o instituto da arbitragem e o tema passou a ser recorrente entre os advogados, em especial aqueles que atendiam clientes estrangeiros ${ }^{26}$.

Tendo em vista o descompasso existente entre a evolução da arbitragem em países estrangeiros e o então insipiente desenvolvimento do instituto no país, o governo federal decidiu dar início à elaboração de um projeto de lei específico sobre o tema. Durante a década de 80, três anteprojetos de lei foram preparados, arquivados e todos continham falhas técnicas ${ }^{27}$. O último arquivamento no final da década de 80 desmotivou acadêmicos e

${ }^{24}$ CARMOnA, Carlos Alberto. Arbitragem e Processo: Um Comentário à Lei ${ }^{\circ}$ 9.307/96, $3^{\text {a }}$ Ed. São Paulo: Atlas, 2009, p. 5.

${ }^{25}$ Neste sentido, TJSP, Apelação n ${ }^{\circ}$ 107.779-2, $14^{\text {a }}$ Câmara, Des. Rel. Domingos Franciulli Netto, julgado em 23 de setembro de 1986, "Para que a 'exceptio ex compromisso' seja aceita deve existir compromisso arbitral perfeito acabado, estando presentes todos os requisitos legais previstos nos arts. 1.039 do CC e 1.074 do CPC, sem os quais a cláusula contratual que prevê a aplicação do instituto será considerada nula. (...) quando muito, o desrespeito a essa cláusula [promessa de compromisso arbitral] poderia gerar uma controvérsia específica sobre o rompimento dessa promessa seja como for, como novo ajuste não foi feito para que o compromisso se aperfeiçoasse".

${ }^{26}$ STRAUBE, Frederico José. "A evolução da arbitragem no Brasil após a Lei 9307/1996”. Revista de Arbitragem e Mediação, vol. 50, 2016, pp. 177-183.

${ }^{27}$ O anteprojeto de lei de 1981 foi elaborado a pedido do extinto Ministério da Desburocratização e buscou modernizar o tratamento da arbitragem no país, equiparando os efeitos da cláusula compromissória aos do compromisso arbitral e eliminando a necessidade de homologação do laudo arbitral perante o Poder Judiciário. No entanto, o trabalho acabou sendo abandonado. O anteprojeto de 1986 não observou a Lei Modelo da UNCITRAL, e confundiu alguns conceitos como "arbitragem" e "arbitramento". Além disso, foi omisso na parte dedicada às sentenças arbitrais estrangeiras, prevendo que bastaria uma tradução juramentada da sentença arbitral para o seu reconhecimento no país, não contemplando a averiguação de eventual ofensa à ordem pública. Em decorrência dessas imprecisões, o projeto foi também descartado. Já o anteprojeto de 1988 apresentou algumas imprecisões técnicas ao, por exemplo, prever que tanto a cláusula compromissória quanto o compromisso deveriam conter uma descrição do objeto do litígio, que o laudo arbitral poderia ser objeto de recurso de apelação e que os árbitros deveriam necessariamente ser bacharéis em direito. $\mathrm{O}$ anteprojeto não tratou da necessidade (ou não) de homologação do laudo e também se manteve silente quanto à homologação de laudo estrangeiro. Sobre o tema, CARMONA, Carlos Alberto. Arbitragem e Processo: Um Comentário à Lei $\mathbf{n}^{\circ}$ 9.307/96, $3^{\text {a }}$ Ed. São Paulo: Atlas, 2009, pp. 5-9. 
advogados quanto à existência de lei específica sobre a arbitragem. Foi então que Petrônio Muniz, advogado do Instituto Liberal de Pernambuco, articulou a chamada "operação arbiter", que culminou no projeto de lei apresentado pelo senador Marco Maciel e que veio a se tornar a Lei de Arbitragem ${ }^{28}$.

A Lei de Arbitragem trouxe mudanças fundamentais para o desenvolvimento do instituto no país ao prever a possibilidade de execução específica da convenção arbitral e dispensar a necessidade de homologação da sentença arbitral perante o judiciário.

Logo após sua promulgação, a constitucionalidade da Lei de Arbitragem foi questionada e analisada pelo STF no âmbito do Agravo Regimental da Sentença Estrangeira $n^{\circ}$ 5.206-7, do Reino da Espanha, em especial no que tange à execução específica da cláusula compromissória e à falta de necessidade de homologação da sentença ${ }^{29}$. Com a conclusão do julgamento, em 2001, foi reconhecida a constitucionalidade da Lei de Arbitragem.

Com a lei e a declaração de sua constitucionalidade, o uso da arbitragem começou a se expandir no país, em especial para litígios de maior complexidade, normalmente envolvendo grandes empresas. De fato, mesmo antes da decisão acerca da constitucionalidade, em 2000, a B3 (então BM\&F Bovespa) lançou o Novo Mercado como segmento especial de listagem com práticas mais sofisticadas de governança corporativa e cuja adesão, pelas companhias, implica na inclusão de um conjunto de regras voltados para ampliação dos direitos dos acionistas e das políticas de divulgação de informações e mecanismos de fiscalização. Para Calixto Salomão Filho, as regras inovadoras do Novo Mercado buscaram maior proteção aos acionistas minoritários e podem ser divididas em três grupos, sendo o primeiro formado pelas garantias de informação completa, que ampliam os requisitos de divulgação de informação previstos na lei societária; o segundo relacionado ao reforço das garantias patrimoniais de saída dos sócios minoritários da companhia; e a

\footnotetext{
${ }^{28} \mathrm{O}$ grupo de trabalho formado para elaboração do projeto de lei era composto por Selma Maria Ferreira Lemes, Pedro Antonio Batista Martins e Carlos Alberto Carmona.

${ }^{29}$ Durante o julgamento, restaram vencidos os ministros Sepúlveda Pertence (relator), Sydney Sanches, Néry da Silveira e Moreira Alves, que entendiam inconstitucionais basicamente os artigos $6^{\circ}$, parágrafo único, $7^{\circ} \mathrm{e}$ 41 da Lei de Arbitragem, que tratam da cláusula compromissória e de sua execução específica. Em suma, o principal argumento que fundamentou a alegada inconstitucionalidade da Lei de Arbitragem foi o fato de que, na celebração do contrato, não seria possível identificar as disputas que se sujeitariam à arbitragem e, portanto, não haveria o consentimento das partes a tal arbitragem.Neste sentido, o Ministro Sepúlveda Pertence no julgamento, "A constitucionalidade do juizo arbitral (...) deriva da renunciabilidade, no caso, do exercício do direito de ação - que é o reflexo subjetivo da garantia da prestação jurisdicional, insculpida hoje no art. 5o, XXXV, da Lei Fundamental - relativamente a uma pretensão material disponível. Mas, a renunciabilidade da ação - porque direito de caráter instrumental - não existe 'in abstracto': só se pode aferi-la em concreto (...) a esse pressuposto de constitucionalidade do juizo arbitral, atende o compromisso, mas não a cláusula arbitral'.
} 
implementação de proteções estruturais na sociedade. As duas primeiras garantias reforçam a proteção da legislação societária vigente, enquanto a terceira, ao alterar normas internas da estrutura da companhia, enfraquece o poder dos controladores e facilita a cooperação entre os acionistas ${ }^{30}$. Dentre as normas do terceiro grupo, estaria a adoção da arbitragem estatutária. O então vigente regulamento do Novo Mercado ${ }^{31}$, portanto, assim como do Nível 2, previa que todas as empresas listadas deveriam aderir à arbitragem pela CAM; sendo, portanto, a cláusula compromissória arbitral item obrigatório do estatuto social. Essa medida se alinhou com o entendimento de que a arbitragem seria provavelmente o melhor método de solução de conflitos societários e do mercado, o que se infere inclusive, do próprio sítio eletrônico da CAM, que diz que a "Câmara de Arbitragem do Mercado (CAM) é o foro mais adequado para resolver disputas societárias e do mercado de capitais" ${ }^{32}$.

Logo depois, em 2001, a Lei 10.303 reformou a Lei das S.A. e incluiu o $§ 3^{\circ}$ ao artigo $109^{33}$, prevendo expressamente a possibilidade de inclusão de cláusula compromissória nos estatutos das sociedades anônimas para solução de conflitos entre acionistas e a companhia e entre acionistas controladores e minoritários. Essa reforma foi ao encontro da tendência de incentivar uso da arbitragem pelas companhias ${ }^{34}$ em atenção ao desenvolvimento e ao maior dinamismo do mercado ${ }^{35}$, atraindo o aporte de capital nacional e estrangeiro e potencializando a captação de recursos para o desenvolvimento das atividades sociais, considerando que a arbitragem (em comparação com o poder judiciário) tende a conferir maior segurança aos investidores, em especial aos estrangeiros ${ }^{36}$. Há até quem afirme que ${ }^{30}$ SALOMÃO FILHO, Calixto. O novo direito societário, $4^{\text {a }}$ Ed., São Paulo: Malheiros, 2011, pp. 69-70.
${ }^{31}$ O Regulamento do Novo Mercado passou por modificações nos anos de 2006, 2011 e, mais recentemente,
em 2017.

32 Sítio eletrônico da CAM: Disponível em <http://www.b3.com.br/pt_br/b3/qualificacao-egovernanca/camara-de-arbitragem-do-mercado-cam/sobre-a-cam/>, acesso em novembro de 2018.

${ }^{33}$ Artigo 109, $\$ 3^{\circ}$ da Lei das S.A.: O estatuto da sociedade pode estabelecer que as divergências entre os acionistas e a companhia, ou entre os acionistas controladores e os acionistas minoritários, poderão ser solucionadas mediante arbitragem, nos termos em que especificar. (Incluído pela Lei $\mathrm{n}^{\mathrm{o}} 10.303$, de 2001)

${ }^{34}$ BARBOSA FILHO, Marcelo Fortes. Sociedade Anônima Atual: Comentários e Anotações às Inovações trazidas pela Lei n. 10.303/ ao texto da Lei n. 6404/76. São Paulo: Atlas, 2004, p. 109.

35 MUNHOZ, Eduardo Secchi. “Arbitragem e Novo Mercado". In: MATTOS FILHO; VEIGA FILHO; MARREY JR.; QUIROGA ADVOGADOS (eds.). Arbitragem no Brasil. São Paulo: Impressão Régia, 2010, p. 28; VALÉRIO, Marco Aurélio Gumieri. “A arbitragem nas sociedades anônimas: vinculação dos acionistas novos, ausentes, dissidentes e administradores à cláusula compromissória estatutária. Inclusão do $\S 3^{\circ}$ ao art. 109 pela Lei 10.303/2001”. Revista de Direito Mercantil Industrial, Econômico e Financeiro, vol. 139, 2005, p. 164: "A arbitragem apresenta-se como um instrumento em consonância com o dinamismo da economia de mercado".

${ }^{36}$ MARTINS, Pedro A. Batista. "A arbitragem no Direito Societário". Revista de Arbitragem e Mediação, vol. 39, 2003, p. 55, “a aliança Arbitragem/S.A. confere maior segurança ao ingresso de capitais estrangeiros em atividades essenciais ao incremento e à melhoria da competitividade em mercados marcados pela globalização e intensa competição. (...) ao analisarmos a função social e econômica que as S.A. exercem no mundo (v.g. catalizadora da poupança popular; geradora de riquezas; contribuinte de relevo nos tributos municipais, estaduais e federais; apoiadora cultural de relevo; fonte incentivadora de projetos e programas 
esse novo parágrafo representaria a adoção da cláusula compromissória como regra, e não exceção ${ }^{37}$. Vale destacar ainda que, em 2002, o Brasil deu outro passo importante para o desenvolvimento da arbitragem no país ao ratificar a Convenção sobre o Reconhecimento e Execução de Sentenças Arbitrais Estrangeiras (mais conhecida como Convenção de Nova Iorque), celebrada em $1958^{38}$.

Não obstante o fato de que essas mudanças representaram um importante avanço para a arbitragem, a CAM demorou a ser utilizada pelas companhias e instaurou-se uma celeuma acerca da extensão subjetiva da cláusula compromissória estatutária que, até pouco tempo, não havia sido resolvida. Em relação à baixa utilização da CAM, esta somente recebeu seus quatro primeiros processos em $2010^{39}$. A baixa atratividade inclusive motivou uma reforma do regulamento em 2011, que incluiu redução da confidencialidade com a previsão de publicação de ementas e alterações nos procedimentos, para redução da burocracia e aumento da fluidez do processo. Desde então, o uso da arbitragem pelas companhias cresceu, inclusive dentre o grupo daquelas não listadas em segmentos de arbitragem obrigatória ${ }^{40}$.

Já em relação à celeuma quanto à arbitrabilidade subjetiva da cláusula compromissória estatutária, a discussão foi baseada no fato de que para a sua inserção no estatuto, não seria necessária a aprovação da totalidade dos acionistas. Salvo no caso de

sociais), é de se concluir que a sua existência torna Estados e nações seus dependentes. (...) Por essas razões, $e$, ainda, pela gradativa e constante inserção do Brasil dentre as maiores economias mundiais ( $7^{a}$ em 2013 e $6^{a}$ em 2012) é que se acentuou a aproximação das S.A. com o instituto da arbitragem". Ainda sobre o tema, WALD, Arnoldo; BORJA, Ana Gerdau e VIEIRA, Maíra de Melo. “A posição dos tribunais em matéria de arbitragem no último biênio (2011-2012)". Revista de Arbitragem e Mediação, vol. 9, n 35, 2012, p. 17, no sentido de que o contexto da descoberta do pré sal, da realização da Copa do Mundo no ano de 2014 e dos Jogos Olímpicos de 2016 gerou a necessidade de formação de joint ventures e, consequentemente, do maior fluxo de investimentos estrangeiros diretos e indiretos no país, o que impulsionou ainda mais o desenvolvimento da arbitragem, em especial, no âmbito societário.

${ }^{37}$ STEIN, Raquel. Arbitrabilidade no Direito Societário. Rio de Janeiro: Renovar, 2014, pp. 115-116, “ $a$ inclusão de uma cláusula compromissória estatutária, não seria uma exceção à regra geral da jurisdição estatal, mas a regra do próprio sistema societário".

${ }^{38}$ Renato Parreira Stetner e Eleonora Coelho Pitombo destacam a importância da ratificação da Convenção de Nova Iorque para o país, dada a sua importância como um dos mais importantes tratados de reconhecimento e execução de sentenças arbitrais do mundo. Ademais, os autores destacam que, não obstante o fato de que boa parte das mudanças já estava incorporada pela Lei de Arbitragem, a ratificação da convenção viabilizou o uso da arbitragem em relações empresariais internacionais, garantiu reciprocidade a parceiros comerciais do país que já eram signatários da convenção e deu mais segurança jurídica a partes estrangeiras, diminuindo a percepção do risco de se fazer negócio no país. Neste sentido, STETNER, Renato Parreira; PITOMBO, Eleonora Coelho. “A Convenção de Nova York: Ratificação pelo Brasil” In: GUILHERME, Luiz Fernando do Vale de Almeida (coord.). Novos Rumos da Arbitragem no Brasil. São Paulo: Editora Fiúza, 2004, pp. 309, 324-325.

39 PEREIRA, Guilherme Setoguti J. Enforcement e Tutela Indenizatória no Direito Societário e no Mercado de Capitais. São Paulo: Quartier Latin, 2018, p. 145.

${ }^{40}$ Sobre a crescente adoção da cláusula compromissória estatutária, vide também: PARGENDLER, Mariana; PRADO, Viviane Muller; BARBOSA JR., Alberto. "Cláusulas arbitrais no mercado de capitais brasileiro". Revista de Arbitragem e Mediação, n 40, 2014, pp. 107-111. 
inclusão da convenção arbitral na constituição da companhia, em que se presume a adesão irrestrita dos subscritores e fundadores ao projeto do estatuto ${ }^{41}$, as reformas estatutárias estariam sujeitas à aprovação da assembleia por decisão da maioria nos termos do artigo 129 da Lei das S.A. ${ }^{42}$. Considerando, de um lado, o princípio majoritário do direito societário ${ }^{43}$ e, de outro, o princípio da autonomia da vontade na arbitragem $^{44}$, instaurou-se uma polêmica

${ }^{41}$ No momento da constituição da sociedade anônima, a lei presume a adesão irrestrita dos subscritores ao teor do estatuto. No caso de companhias abertas, por meio de subscrição pública e capitalização no mercado, todos os subscritores manifestam sua concordância com o projeto do estatuto, ainda que ausentes da assembleia de constituição, tendo em vista que o projeto foi necessariamente submetido à aprovação prévia pelos fundadores. No caso de companhias fechadas, a constituição ocorre por meio de subscrição particular em assembleia geral ou por meio da celebração de escritura pública, sendo que, em ambos os casos, há a manifestação do consentimento dos acionistas, seja na assinatura do projeto apreciado pela assembleia geral ou da escritura pública de constituição. Sobre o tema: ROSSI, Lívia. "Arbitragem na Lei das Sociedades Anônimas". Revista de Direito Mercantil Industrial, Econômico e Financeiro, vol. 129, 2003, p. 197; CARVALHOSA, Modesto. Comentários à Lei de Sociedades Anônimas (arts. 75 a 137), $6^{a}$ Ed., vol. 2. São Paulo: Saraiva, 2014, p. 392, "os fundadores-subscritores da sociedade não aderem ao estatuto, mas originalmente o aprovam. Importante a distinção. No caso, os atos constitutivos e, entre eles, a aprovação do estatuto são 'tratactus' entre os fundadores e não 'dictatus'. O caráter de dictatus do estatuto social somente se dá no caso de aquisição de ações posteriormente aos atos constitutivos".

${ }^{42} \mathrm{O}$ princípio majoritário, portanto, pressupõe a unanimidade entre os sócios pelo menos no momento da constituição da sociedade. Neste sentido, COMPARATO, Fábio Konder; SALOMÃO FILHO, Calixto. O poder de controle na sociedade anônima, $6^{\text {a }}$ Ed. São Paulo: Forense, 2014, p. 52.

${ }^{43}$ No estudo de direito societário, a discussão sobre os fundamentos da aplicação do princípio majoritário no processo de formação das deliberações sociais é objeto de vasta literatura, cuja revisão não está no escopo do presente trabalho. As deliberações sociais podem ser tomadas por unanimidade ou por certo número majoritário de votos a favor. Em relação à unanimidade, ela pode assumir uma forma mais rigorosa, na qual não são computadas abstenções e uma outra em que se consideras as abstenções. Sobre este tema, vide COELHO, Eduardo de Melo Lucas. A formação das deliberações sociais. Coimbra: Coimbra Editora, 1994, pp. 318-319 (nota 318). Independentemente dos fundamentos, porém, o afastamento da unanimidade e a aplicação de menor percentual de aprovação pelo princípio majoritário é uma exigência prática. Neste sentido: ADAMEK, Marcelo Vieira von. Abuso de minoria em direito societário. São Paulo: Malheiros, 2014, pp. 43-44 "apenas ele possibilita, no tráfego jurídico, a necessária formação unitária da vontade coletiva: exigir a unanimidade asseguraria a participação de todos em cada decisão, mas tornaria a sociedade incapaz de agir", p. 49 (nota 37): "Em realidade, as múltiplas tentativas de explicação lógica do princípio majoritário pouco acrescentam: ele é uma exigência prática e não necessariamente lógica"; J. X. CARVALHO DE MENDONÇA. Tratado de Direito Comercial Brasileiro, 5 Ed., vol. IV. Rio de Janeiro: Freitas Bastos, 1954, p. 11, "Exigir a unanimidade seria expor a sociedade à inação, seria cair no absurdo de atribuir a um só acionista a qualidade de representante ou árbitro da vontade social"; ASCARELLI, Tullio. "O contrato plurilateral". Problemas das sociedades anônimas e direito comparado, $2^{\mathrm{a}}$ Ed. São Paulo: Saraiva, 1969, p. 259. "a uma pluralidade de pessoas e, portanto, a uma pluralidade de manifestações de vontade, corresponde uma única parte; as várias manifestações de vontade são destinadas a fundir-se. Nessa hipótese, vigora, às vezes, a regra da maioria, justamente porque se trata de determinar, através do concurso de mais manifestações de vontade, qual é a vontade da "parte"'.

${ }^{44}$ HANOTIAU, Bernard. Complex Arbitrations: Multiparty, Multicontract, Multi-issue and Class Actions (International Arbitration Law Library). Kluwer Law International, 2005, p. 32, "Consent is the foundation of arbitration, and in general a court or an arbitral tribunal will refuse to treat a person or entity as a party to the contract or at least to the arbitration clause if it has not expressly or implicitly consented to $i t$, a fact that in most - but not all - cases will be expressed by the signature of the person or entity concerned on a contractual document"; LEMES, Selma Maria Ferreira. "Princípios e Origens da Lei de Arbitragem". Revista do Advogado, n 51, 1997, p. 32, "O Princípio da Autonomia da Vontade é a mola propulsora da arbitragem em todos os seus quadrantes, desde a faculdade de as partes em um negócio envolvendo direitos patrimoniais disporem quanto a esta via opcional de solução de conflitos (art. $1^{\circ}$ ), até como será desenvolvido o procedimento arbitral, no que pertine à forma de indicação dos árbitros (art. 13); a lei aplicável à arbitragem, seja material ou formal, desde que não viole os bons costumes e a ordem pública (art. $2^{\circ}, \S \$ 1^{o} e$ $2^{\circ}$ ); se a decisão será de direito ou por equidade (art. $2^{\circ}$ ); eleger a arbitragem institucional (art. $5^{\circ}$ ); prazo 
a respeito da vinculação de acionistas que entrassem no quadro societário posteriormente à inclusão da cláusula compromissória, bem como a respeito dos acionistas ausentes e dissidentes da deliberação assemblear que aprovar a adesão à arbitragem. A discussão parte da premissa de que, aos novos acionistas e aos ausentes faltaria a manifestação de vontade ${ }^{45}$ e, em relação aos dissidentes, haveria, na verdade, expressa manifestação contrária ao dispositivo estatutário.

A controvérsia foi objeto de intensos debates, em decorrência, em especial, dos seus efeitos práticos. Caso se admitisse a vinculação parcial dos acionistas à cláusula compromissória, seria possível que as mesmas disputas fossem submetidas a jurisdições distintas (arbitral e estatal), estando, portanto, passíveis de serem decididas de formas diferentes. De outro lado, a vinculação de todos acionistas poderia ser considerada uma violação da garantia constitucional de acesso ao judiciário e do princípio da autonomia da vontade na arbitragem. Assim, a doutrina se dividiu sobre o tema: de um lado, aqueles que defendiam a não vinculação automática dos acionistas à arbitragem, salvo no caso de manifestação expressa e, de outro, aqueles que advogavam pela vinculação de todos a partir da aprovação da reforma estatutária.

Em suma, na visão de Modesto Carvalhosa, para os novos acionistas da sociedade não deveria haver uma vinculação "automática" à cláusula compromissória, uma vez que a opção pela arbitragem representa a renúncia à solução de conflitos pela via judicial, sendo, portanto, necessária adesão expressa e inequívoca à convenção arbitral manifesta em

para o árbitro proferir a sentença arbitral (arts. 11, inciso III e 23). Enfim o princípio da autonomia da vontade atinge sua quinta-essência na lei $n^{\circ}$ 9,307/96"; MARTINS, Pedro A. Batista. Arbitragem no Direito Societário. São Paulo: Quartier Latin, 2012, p. 33, “Autonomia esta que, mais que uma faculdade, é verdadeiro poder, pois se traduz no extremo da autorregulação. Encerra o poder de definir aquilo que mais lhe interessa, o que lhe seja mais conveniente, inclusive o de abdicar de direitos e de se impôr deveres"; CAHALI, Francisco José. Curso de Arbitragem. São Paulo: Revista dos Tribunais, 2011, p. 87, “A origem da arbitragem é contratual, pois as partes, no exercício da autonomia da vontade, resolvem subtrair do Judiciário a solução do conflito de interesses, entregando a tarefa ao particular"; ENEI, José Virgílio Lopes. "A arbitragem nas sociedades anônimas". Revista de Direito Mercantil Industrial, Econômico e Financeiro, vol. 129, 2003, p. 142, "o fato é que a arbitragem, na perspectiva do regime legal brasileiro bem como das legislações mais modernas, só tem lugar a partir ti acordo entre as partes envolvidas no sentido de submeter o conflito (esteja ele já instaurado, ou seja ele apenas potencial) a um tribunal arbitral".

${ }^{45}$ VALÉRIO, Marco Aurélio Gumieri. “A arbitragem nas sociedades anônimas: vinculação dos acionistas novos, ausentes, dissidentes e administradores à cláusula compromissória estatutária. Inclusão do $\S 3^{\circ}$ ao art. 109 pela Lei 10.303/2001”. Revista de Direito Mercantil Industrial, Econômico e Financeiro, vol. 139, 2005 , p. 171. 
documento separado e por escrito ${ }^{46}$. No mesmo sentido, Luiz Leonardo Cantidiano ${ }^{47}$, José Waldecy Lucena ${ }^{48}$ e Jorge Lobo ${ }^{49}$.

Os principais argumentos relacionados a essa tese são: (i) a dimensão negativa da cláusula compromissória, que implica no afastamento do poder judiciário; e (ii) a natureza facultativa da cláusula compromissória estatutária ${ }^{50}$, já que esta (a) não teria caráter associativo e, por isso, não seria oponível a todos os acionistas ${ }^{51}$; (b) seria matéria optativa do estatuto social, desprovida de natureza organizativa e, portanto, sua eficácia não poderia ser imposta aos não signatários ${ }^{52}$; e (c) teria natureza de pacto parassocial entre a sociedade e os acionistas que a tenham aprovado ou aderido expressamente a ela ${ }^{53}$.

${ }^{46}$ CARVAlHOSA, Modesto. "Cláusula Compromissória Estatutária e Juízo Arbitral". In: LOBO, Jorge (coord.) Reforma da Lei das Sociedades Anônimas: Inovações e Questões Controvertidas da Lei 10.303, de 31 de outubro de 2001. $1^{\text {a }}$ Ed. Rio de Janeiro: Forense, 2002, p. 325; CARVALHOSA, Modesto; EIZIRIK, Nelson. A Nova Lei das S/A. São Paulo: Saraiva, 2002 p. 185. "O novo acionista não será parte na cláusula compromissória pelo simples fato de ter passado a integrar o colégio acionário, a não ser que, por escrito, em documento apartado revestido de todas as formalidades, tenha aderido ao pacto, em conformidade com o $\$ 2^{\circ}$ do art. $4^{\circ}$ da Lei n. 9.307/96". Vale destacar que, não obstante a manifestação de Nelson Eizirik na obra mecionada, o autor alterou seu entendimento, conforme dito no evento Debate sobre a Constitucionalidade do Artigo 136-A da Lei das S.A., organizado pela FIESP, em 25 de abril de 2018.

${ }^{47}$ CANTIDIANO, Luiz Leonardo. Reforma da Lei das S.A. Comentada. Rio de Janeiro: Renovar, 2002, pp. 118-119, "Inserida, no estatuto, norma que estabeleça a submissão de eventuais conflitos à arbitragem, o acionista, ao tornar-se titular de ações de emissão da companhia, estará 'aderindo' ao contrato, pelo que ficará obrigado a acatar e decisão que vier a ser proferida no juízo arbitral. Cabe indagar se, à vista de disposição expressa que consta do $\$ 2^{\circ}$, do art. $4^{\circ}$, da lei $9.307 / 96$, deve ser observado o procedimento ali previsto para que o acionista da companhia fique obrigado a submeter-se ao procedimento arbitral. (...) penso ser prudente fazer com que seja cumprido o ritual estabelecido no referido dispositivo, a fim de evitar discussões paralelas que possam colocar em risco a solução da controvérsia pela adoção do procedimento arbitral".

${ }^{48}$ LUCENA, José Waldecy. Das Sociedades Anônimas - Comentários à Lei (arts. $\mathbf{1}^{\mathbf{0}}$ a 120), vol. I. Rio de Janeiro: Renovar, 2009, p. 1018.

${ }^{49} \mathrm{Em} 25$ de abril de 2018, a FIESP organizou um Debate sobre a Constitucionalidade do Artigo 136-A da Lei das S.A., no qual Jorge Lobo, juntamente com Modesto Carvalhosa, reafirmou a necessidade de adesão expressa à cláusula compromissória estatutária para fins de vinculação dos acionistas ausentes, dissidentes e novos.

${ }^{50}$ Nesta segunda parte, agruparemos as discussões da cláusula enquanto disposição facultativa e pacto parassocial, e também o argumento do estatuto social como contrato de adesão.

${ }^{51}$ CARVAlHOSA, Modesto; EIZIRIK, Nelson. A Nova Lei das S/A. São Paulo: Saraiva, 2002, p. 185; CARVALHOSA, Modesto. Comentários à Lei de Sociedades Anônimas (arts. 75 a 137), 6 ad., vol. 2. São Paulo: Saraiva, 2014, p. 400, "a renúncia ao direito essencial de valer-se do Poder Judiciário, para dirimir divergências e litígios de natureza societária (arts. $5^{\circ}, X X X V$, e 60, $\$ 4^{\circ}$, da CF e \$2 deste art. 109) é personalíssima, não se podendo, sob nenhum pretexto, ainda que contratual, convencionar a sua sucessão".

${ }^{52}$ CARVALHOSA, Modesto. Comentários à Lei de Sociedades Anônimas (arts. 75 a 137), 6 a Ed., vol. 2. São Paulo: Saraiva, 2014, p. 390, "A cláusula compromissória constitui matéria facultativa e, portanto, potestativa do estatuto social. Não se confunde com as matérias que obrigatoriamente deverão dele constar, que são específicas da Sociedade Anônima, ditadas pela lei. Distingue-se, dessa forma, a cláusula estatutária potestativa, que consubstancia o pacto compromissório, daquelas cláusulas mandatórias".

${ }^{53}$ CARVALHOSA, Modesto. Comentários à Lei de Sociedades Anônimas (arts. 75 a 137), 6 a Ed., vol. 2. São Paulo: Saraiva, 2014, pp. 395-396, "A sociedade despe-se, por conseguinte, do seu poder de impor a todos os acionistas a cláusula compromissória estatutária, na medida em que se coloca como parte no pacto comissório diante de outras partes (...) A cláusula compromissória estatutária constitui, portanto, um pacto parassocial entre a sociedade e os seus fundadores e acionistas que aprovaram a sua inclusão ou que expressamente aderiram a seus termos". 
Para esse grupo de autores, considerando que a arbitragem implica no afastamento do judiciário, fazer com que os novos acionistas se vinculassem automaticamente à cláusula representaria uma violação ao direito constitucional de que "a lei não excluirá da apreciação do Poder Judiciário lesão ou ameaça a direito", nos termos do artigo $5^{\circ}, \mathrm{XXXV}$ e $60 \S^{\circ}$, da Constituição Federal ${ }^{54}$, e reiterado no $\$ 2^{\circ}$ do artigo 109 da Lei das S.A. ${ }^{55}$.

Por outro lado, tal posicionamento parece partir de uma visão limitada do conceito de jurisdição restrita apenas à jurisdição estatal, sendo que se reconhece o caráter jurisdicional da arbitragem ${ }^{56}$ e o objetivo da proteção constitucional e legal é, na verdade, o de garantir o direito da pessoa (do acionista, no caso) de deduzir sua pretensão em juízo, seja arbitral ou estatal ${ }^{57}$.

Se o acesso ao Poder Judiciário fosse o direito essencial em si, ele seria irrenunciável ainda que a vontade dos acionistas fosse pelo seu afastamento ${ }^{58}$. Assim, da mesma forma que os particulares podem transacionar sobre suas disputas ${ }^{59}$, se é permitida a opção de submeter litígios relativos a direitos disponíveis à arbitragem, isso só ocorre, porque o Estado consente e autoriza ${ }^{60}$. Sob essa perspectiva, a inclusão da cláusula compromissória seria

\footnotetext{
${ }^{54}$ Artigo $5^{\circ}, \mathrm{XXXV}$, Constituição Federal. A lei não excluirá da apreciação do Poder Judiciário lesão ou ameaça a direito; Artigo 60, $\S 4^{\circ}$, IV, Constituição Federal. Não será objeto de deliberação a proposta de emenda tendente a abolir (...) os direitos e garantias individuais.

${ }^{55}$ Artigo $109, \S 4^{\circ}$ da Lei das S.A.: Os meios, processos ou ações que a lei confere ao acionista para assegurar os seus direitos não podem ser elididos pelo estatuto ou pela assembléia-geral.

${ }^{56}$ GUERREIRO, José Alexandre Tavares. Fundamentos da arbitragem do comércio internacional. São Paulo, Saraiva, 1993, pp. 59-60, “a arbitragem corresponde efetivamente, a uma forma de heterocomposição de situações contenciosas, mediante a aplicação de normas jurídicas (tanto do 'ius strictum' quanto da equidade), o que, a nosso ver, lhe confere caráter essencialmente jurisdicional. Tal caráter se identifica, segundo pensamos, sempre que o 'tertius' (árbitro ou tribunal arbitral) toma a decisão concernente aos interesses das partes, não sendo seu representante ou mandatário, e o faz de forma independente, obrigando o decidido às próprias partes, segundo o que elas pactuaram".

57 VALÉRIO, Marco Aurélio Gumieri. “A arbitragem nas sociedades anônimas: vinculação dos acionistas novos, ausentes, dissidentes e administradores à cláusula compromissória estatutária. Inclusão do $\$ 3^{\circ}$ ao art. 109 pela Lei 10.303/2001”. Revista de Direito Mercantil Industrial, Econômico e Financeiro, vol. 139, 2005 , p. 167.

58 VALÉRIO, Marco Aurélio Gumieri. “A arbitragem nas sociedades anônimas: vinculação dos acionistas novos, ausentes, dissidentes e administradores à cláusula compromissória estatutária. Inclusão do $\$ 3^{\circ}$ ao art. 109 pela Lei 10.303/2001”. Revista de Direito Mercantil Industrial, Econômico e Financeiro, vol. 139, 2005, p. 168; ENEI, José Virgílio Lopes. "A arbitragem nas sociedades anônimas". Revista de Direito Mercantil Industrial, Econômico e Financeiro, vol. 129, 2003, p. 148.

${ }^{59}$ MARQUES, José Frederico. Instituições de Direito Processual, vol. 5. Rio de Janeiro: Forense, 1960, p. 423, “Assim como o Estado, por estar em foco direito disponível, deixa que os interessados solucionem, através de transação, suas desinteligências recíprocas, nada há de estranhável que, também, autorize, esses mesmos interessados, a submeterem a resolução do conflito a outras pessoas, em lugar de o levaram, através da propositura da ação, a juízes e tribunais. Nem há, com isso, transgressão do art. 141, par. 4o, da Constituição Federal ou infringência do princípio do juiz natural (retro, par. 16). O direito individual, no caso, passa a ser, tal como na transação, aquele que, em virtude acordo consubstanciado no compromisso, foi definido no laudo arbitral".

${ }^{60}$ CARREIRA ALVIM, J. E., Tratado Geral da Arbitragem Interno. Belo Horizonte: Mandamentos, 2000, p. 55.
} 
meramente o exercício da opção por um meio alternativo de resolução de controvérsias e a vinculação do novo acionista, portanto, não representaria nenhuma forma de afronta à proteção constitucional de acesso à justiça. Além disso, considerando que, segundo o STF, a escolha da arbitragem não ofende a garantia constitucional de acesso à jurisdição ${ }^{61}$, não parece razoável mudar esse entendimento para litígios societários ${ }^{62}$.

Adicionalmente, para os defensores da não vinculação dos novos acionistas à convenção arbitral estatutária, esta não teria o caráter associativo, típico da maioria das disposições estatutárias, e, portanto, não poderia ser oposta a todos os acionistas, mas somente aos que tiverem expressamente aderido a ela. A sua natureza seria, na verdade, de pacto parassocial ${ }^{63}$. Para Modesto Carvalhosa ${ }^{64}$, o estatuto social, enquanto principal documento organizativo da companhia seria formado por cláusulas organizativas mandatórias e cláusulas potestativas. As primeiras teriam conteúdo livre desde que não vedado por lei e imposto indistintamente a todos os acionistas, em observância ao princípio de igualdade. As segundas, por outro lado, seriam facultativas ${ }^{65}$. Como consequência, a

${ }^{61}$ Trecho do voto do ministro Nelson Jobim, por ocasião do julgamento do Agravo Regimental da Sentença Estrangeira $\mathrm{n}^{\circ}$ 5.206-7, "não há nenhuma vedação constitucional a que partes, maiores e capazes, ajustem a submissão de conflitos, que possam decorrer de relações jurídicas provenientes de contrato específico, ao sistema de arbitragem. Não há renúncia abstrata à jurisdição. Há, isto sim, convenção de arbitragem sobre litígios futuros e eventuais, circunscritos a específica relação contratual, rigorosamente determináveis. Há renúncia relativa à jurisdição. Circunscreve-se a renúncia aos litígios que decorram do pacto contratual, nos limites fixados pela cláusula. Não há que se ler na regra constitucional (art. 5, XXXV), que tem como destinatário o legislador, a proibição de as partes renunciarem à ação judicial quanto a litígios determináveis, decorrentes de contrato específico. Lá não se encontra essa proibição. Pelo contrário, o texto proíbe o legislador, não o cidadão. É o reconhecimento da liberdade individual. É esse o âmbito de validez da Lei $n^{o}$ 9.307/96”.

${ }^{62}$ PELA, Juliana Krueger. “Notas sobre a eficácia da cláusula compromissória estatutária”. Revista de Direito Mercantil Industrial, Econômico e Financeiro, vol. 126, ano XLI, 2002, p. 136; FLAKS, Luís Lória. “A arbitragem na reforma da lei das Sociedades Anônimas". Revista de Direito Mercantil Industrial, Econômico e Financeiro, vol. 131, ano XLII, 2003, p. 107; MARQUES, Ricardo Vilagra da Silva. "A eficácia da cláusula compromissória estatutária: uma questão (ainda) controvertida”. In: GUILHERME, Luiz Fernando do Vale de Almeida. Novos Rumos da Arbitragem no Brasil. São Paulo: Fiuza Editores, 2004, pp. 359-360. ${ }^{63}$ Sobre a definição de "parassocial", LEÃES, Luiz Gastão Paes de Barros. "Pactos parassociais. Natureza jurídica. Execução específica. Opção de recompra de participação societária e inexistência de infringência dos arts. 288 do CComercial e 1.372 do CC, por não configurar pacto leonino". Revista dos Tribunais, vol. 601, ano 74, p. 43, "longe de ter por objeto a implementação sistemática ou orgânica do próprio estatuto social, esses contratos parassociais regulam interesses pessoais dos sócios, encarados "uti singuli".

${ }^{64}$ CARVALHOSA, Modesto. "Cláusula Compromissória Estatutária e Juízo Arbitral”. In: LOBO, Jorge (coord.) Reforma da Lei das Sociedades Anônimas: Inovações e Questões Controvertidas da Lei 10.303, de 31 de outubro de 2001. $1^{\text {a }}$ Ed. Rio de Janeiro: Forense, 2002, p. 329 e ss.

${ }^{65} \mathrm{O}$ entendimento de que a cláusula compromissória estatutária é matéria facultativa do estatuto, configurando um pacto parassocial e, portanto, oponível apenas àqueles que tenham expressamente aderido a ela, deriva também do princípio da autonomia da cláusula compromissória. $\mathrm{O}$ artigo $8^{\circ}$ da Lei de Arbitragem prevê que "a cláusula compromissória é autônoma em relação ao contrato em que estiver inserta, de tal sorte que a nulidade deste não implica, necessariamente, a nulidade da cláusula compromissória", assim como também está previsto no artigo 16(1) da Lei Modelo da UNCITRAL, "The arbitral tribunal may rule on its own jurisdiction, including any objections with respect to the existence or validity of the arbitration agreement. For that purpose, an arbitration clause which forms part of a contract shall be treated as an agreement independent 
cláusula compromissória só vincularias acionistas que a tivessem aprovado ou expressamente aderido a ela.

Esse argumento é bastante questionado. Primeiramente, porque parte da premissa de que faltaria aos novos acionistas (e também aos ausentes) a manifestação de vontade em relação à arbitragem. Ocorre que, ao se tornar acionista de determinada sociedade, o acionista deve estar ciente e concordar com as regras societárias e estatutárias aplicáveis ${ }^{66}$, inclusive com o fato de que algumas matérias serão aprovadas por maioria ${ }^{67}$. Pelo princípio majoritário, todos os acionistas se sujeitam à deliberação que resultou da vontade da maioria e que é atribuída à sociedade. ${ }^{68}$ Além disso, seria inadmissível outorgar ao acionista a

of the other terms of the contract. A decision by the arbitral tribunal that the contract is null and void shall not entail 'ipso jure' the invalidity of the arbitration clause". A doutrina da "separabilidade", aqui entendida como a separação da cláusula compromissória em relação ao contrato principal em que está inserida, protege a cláusula compromissória de eventual nulidade do contrato. Desta forma, a jurisdição do tribunal arbitral apenas é afetada quando o vício originador da nulidade do contrato também afetar a cláusula compromissória. Neste sentido, UNCITRAL 2012 Digest of Case Law on the Model Law on International Commercial Arbitration, p. 76, "article 16 (1) only deals explicitly with the impact of the principle on jurisdictional issues. It does so in its last sentence, according to which a finding that the contract is null and void will not necessarily entail the invalidity of the arbitration clause contained therein. The arbitral tribunal's jurisdiction will only be affected where the defect causing the invalidity of the main contract necessarily extends, by its very nature, to the arbitration clause". Sobre a doutrina da separabilidade e seus fundamentos, BORN, Gary B. International Commercial Arbitration. Kluwer Law International, 2009, pp. 336-337; LEW, Julian M.; MISTELIS Loukas A.; KRÖLL, Stefan Michael. Comparative International Commercial Arbitration. Kluwer Law International, 2003, pp. 99-100; BLACKABY, Nigel; PARTASIDES, Constantine; REDFERN, Alan; HUNTER, J. Martin. International Arbitration. Oxford University Press, 2009, p. 94, ENEI, José Virgílio Lopes. "A arbitragem nas sociedades anônimas". Revista de Direito Mercantil Industrial, Econômico e Financeiro, vol. 129, 2003, p. 149; VALÉRIO, Marco Aurélio Gumieri. "A arbitragem nas sociedades anônimas: vinculação dos acionistas novos, ausentes, dissidentes e administradores à cláusula compromissória estatutária. Inclusão do $\S 3^{\circ}$ ao art. 109 pela Lei 10.303/2001”. Revista de Direito Mercantil Industrial, Econômico e Financeiro, vol. 139, 2005, pp. 168-169; MARTINS, Pedro A. Batista. "Cláusula Compromissória" In: MARTINS, Pedro A. Batista, LEMES, Selma M. Ferreira; CARMONA, Carlos Alberto. Aspectos fundamentais da lei de arbitragem. Rio de Janeiro: Forense, 1999, p. 217.

${ }^{66}$ Conforme mencionado por Marcelo Vieira von Adamek (em ADAMEK, Marcelo Vieira von. Abuso de minoria em direito societário. São Paulo: Malheiros, 2014, p. 46), Waldemar Ferreira teria se manifestado no seguinte sentido, "Ao ingressar para a sociedade, seja de que tipo for, o indivíduo aliena parte de sua independência: renuncia a alguns direitos em benefício de pessoa jurídica, para cuja formação contribui ou de que coparticipa" (em FERREIRA, Waldemar. O direito insurrecional do acionista (memorial). São Paulo: Empresa Gráfica da Revista dos Tribunais, 1938, pp. 6-7).

${ }^{67}$ ADAMEK, Marcelo Vieira von. Abuso de minoria em direito societário. São Paulo: Malheiros, 2014, pp. 46-47, "Embora o sócio sempre participe da formação da vontade coletiva (através do voto ou, pelo menos, da sua participação nos conclaves, com direito de voz), fica sujeito, nas sociedades onde prevalece o princípio majoritário, à decisão tomada pela maioria (de sócios ou sócios representando a maioria do capital social, conforme o caso").

68 ASCARELLI, Tullio. "Vícios das deliberações assembleares - direitos individuais dos acionistas, prescrição". Problemas das sociedades anônimas e direito comparado. São Paulo: Quórum, 2008, p. 399, "Esta vontade decorre das manifestações de vontade de mais pessoas: estas se fundem naquela que vale como manifestação única da parte, conforme as regras da maioria". O mesmo princípio de vinculação da totalidade dos sócios à deliberação social se aplica às sociedades limitadas, vide MORAES, Luiza Rangel de. "O regime de deliberações na sociedade limitada em confronto com o processo deliberativo na sociedade anônima". Revista de Direito Bancário, do Mercado de Capitais e da Arbitragem, vol. 21, 2003, pp. 225-250, "A deliberação vincula todos os sócios, mesmo os ausentes e os dissidentes, desde que tenha sido tomada pelo órgão competente e observadas todas as formalidades legais e contratuais pertinentes". 
prerrogativa de escolher a quais disposições estatutárias irá se vincular ou não ${ }^{69}$. Quanto à alegação de que a cláusula compromissória teria natureza jurídica de pacto parassocial, como um acordo de acionistas, é preciso ponderar sobre uma diferença essencial entre eles: enquanto a cláusula compromissória está inserida no estatuto, como resultado da aprovação da assembleia ${ }^{70}$, acordos de acionistas são ajustes celebrados entre os acionistas e independentes dos atos constitutivos da sociedade ${ }^{71}$. Assim, não nos parece que a convenção estatutária seja norma facultativa ou tenha natureza de pacto parassocial.

Por fim, para Modesto Carvalhosa, a necessidade de manifestação expressa de opção pela cláusula compromissória decorreria também da equiparação do estatuto social a um contrato de adesão ${ }^{72}$, uma vez que novos sócios não têm a opção de discutir seus termos,

${ }^{69}$ ENEI, José Virgílio Lopes. "A arbitragem nas sociedades anônimas". Revista de Direito Mercantil Industrial, Econômico e Financeiro, vol. 129, 2003, p. 150, "Não se pode conceber que o novo acionista tenha o direito de escolher os direitos e as obrigações a que estará sujeito sob pena de se inviabilizar por completo a condução dos negócios sociais". O autor ainda completa com a reflexão de que, se fosse aceitável a premissa de que o acionista pode não se vincular à cláusula compromissória por não ter tomado conhecimento dela previamente, haveria risco de questionamento a respeito da vinculação a outras cláusulas estatutárias, como disposições sobre limitações do direito de voto ou restrições à circulação das ações, por exemplo. Em relação às companhias abertas de modo especial, que são obrigadas a divulgar todos os seus documentos societários, o acesso a tais informações é bastante fácil. Caso o investidor tome uma decisão por falta de verificação das informações disponíveis, deverá assumir as consequências da decisão desinformada.

${ }^{70}$ TOLEDO, Paulo Fernandes Campos Salles. “A Arbitragem na Lei das Sociedades Anônimas”. In: CASTRO, Rodrigo R. Monteiro de; ARAGÃO, Leandro Santos de (orgs.). Sociedade Anônima 30 anos da Lei 6.404/76, $1^{a}$ Ed. São Paulo: Quartier Latin, 2007, p. 266, “a cláusula compromissória, por estar inserida no estatuto, é fruto da vontade da própria sociedade, expressa por seu órgão mais relevante, a assembleia geral. Não se trata, além disso, de ato alheio ao estatuto social e sim, muito pelo contrário, parte integrante dele"; ENEI, José Virgílio Lopes. "A arbitragem nas sociedades anônimas". Revista de Direito Mercantil Industrial, Econômico e Financeiro, vol. 129, 2003, p. 145, VERÇOSA, Haroldo Malheiros Duclerc. Curso de Direito Comercial, $2^{a}$ Ed., vol. 3. São Paulo: Malheiros, 2011, pp. 351-352. A definição de "vontade social" e de "interesse social" é objeto de literatura extensa. Para fins deste capítulo, utilizaremos a expressão "vontade social" com o significado da deliberação tomada em Assembleia geral, devidamente convocada e instalada. Neste sentido, BULGARELLI, Waldirio. "Deliberar não deliberar é deliberar?". In: Questões de Direito Societário. São Paulo: Revista dos Tribunais, 1983, p. 86, "Dentro do quadro organizacional das companhias, apresenta-se a assembleia geral como o órgão de formação de sua vontade social, soberana, no sentido de poder primário decorrente a sua conformação e funcionamento diretamente da Lei e do estatuto e não de outros órgãos, como o de administração que dela deriva".

${ }^{71}$ GUERREIRO, José Alexandre Tavares; LACERDA TEIXEIRA, Egberto. Das sociedades anônimas no direito brasileiro, vol. I. São Paulo: José Bushatsky, 1979, pp. 303-304, "podem ser definidos os acordos de acionistas como ajustes parassociais, ou seja, celebrados sem a interveniência da sociedade e alheios a seus atos constitutivos e alterações posteriores, mediante os quais os acionistas convencionam".

${ }^{72}$ A equiparação do estatuto social a um contrato de adesão é aplicada principalmente na doutrina italiana, que invoca, por analogia, o disposto no artigo 1.341 do código civil italiano, que diz "Le condizioni generali di contratto predisposte da uno dei contraenti sono efficaci nei confronti dell'altro, se al momento della conclusione del contratto questi le ha conosciute o avrebbe dovuto conoscerle usando l'ordinaria diligenza. In ogni caso non hanno effetto, se non sono specificamente approvate per iscritto, (...) clausole compromissorie o deroghe alla competenza dell'autorità giudiziaria". Segundo tal dispositivo, cláusulas que atribuem prerrogativas não equitativas, como a cláusula compromissória, não teriam eficácia exceto se aprovadas por escrito. Como ao novo acionista, em geral, não é permitido renegociar os termos já estabelecidos no estatuto social e é possível que ele esteja em posição de hipossuficiência econômica e informacional em relação à companhia, esse dispositivo poderia ser invocado por analogia. No entanto, o entendimento jurisprudencial parece apontar para a não aplicação de referido artigo aos contratos de sociedade, justamente pela convergência de interesses voltados a um objetivo comum, o que não ocorre nos contratos bilaterais, em que as partes têm 
mas tão somente de aderir a eles. Neste caso, considerando que as cláusulas são basicamente ditadas de uma parte a outra, sua interpretação deveria favorecer o aderente. Se, de um lado, é possível que não exista muito poder de barganha do acionista em relação às disposições estatutárias; de outro, parecem faltar características próprias do contrato de adesão, como a obrigatoriedade de contratação pelo aderente por faltar outra forma de satisfazer seu interesse ${ }^{73-74}$, a hipossuficiência de uma das partes em relação àquela que ditou os termos do contrato $^{75}$, e a divergência de interesses entre as partes $^{76}$. Contratos de adesão são

interesses opostos. Sobre este tema, MOREIRA, Daniela Bessone Barbosa. "A Convenção Arbitral em Estatutos e Contratos Sociais". In: ALMEIDA, Ricardo Ramalho (coord.). Arbitragem Interna e Internacional: Questões de Doutrina e da Prática. São Paulo: Renovar, 2003, pp. 375-376.

${ }^{73} \mathrm{O}$ contrato de adesão é caracterizado por ter seu conteúdo definido de forma prévia e unilateral por uma das partes, restando à outra aceitar as cláusulas estabelecidas, sem gozar da discussão que precede a formação dos contratos. A contra-parte que não estipulou o conteúdo contratual pode aderir a ele, de forma expressa, quando há declaração verbal ou escrita, ou de forma tácita, quando age de modo consentâneo com o conteúdo do contrato. Sobre o tema: TOLEDO, Paulo Fernandes Campos Salles. "A Arbitragem na Lei das Sociedades Anônimas". In: CASTRO, Rodrigo R. Monteiro de; ARAGÃO, Leandro Santos de (orgs.). Sociedade Anônima 30 anos da Lei 6.404/76. $1^{\mathrm{a}}$ Ed. São Paulo: Quartier Latin, 2007, pp. 266-267, na "concordância da parte aderente, esgota-se o âmbito da manifestação de sua vontade. Ou seja: cabe-lhe apenas optar se irá contratar ou não.”, PEREIRA, Caio Mário da Silva. Instituições de Direito Civil. 22ª Ed., vol. III. Rio de Janeiro: Forense, 2018, p. 65, "Quando o usuário do serviço se prevalece dele, ou quando o homem do povo entra em relações com a empresa, não discute condições nem debate cláusulas. A sua participação no ato se limita a dar sua adesão ao paradigma contratual já estabelecido, presumindo-se sua aceitação da conduta que adota. Algumas vezes esta adesão é expressa, como no caso em que o aceitante a declara verbalmente ou mediante aposição de sua assinatura em formulário; outras vezes é tácita, se o usuário apenas assume um comportamento consentâneo com a adoção das cláusulas contratuais preestatuídas".

${ }^{74}$ Para Orlando Gomes, o traço realmente distintivo desse tipo de contrato é o fato de que o aderente não pode deixar de contratar. É o que ocorre, por exemplo, em contratos de fornecimento de luz, água e gás, ou de prestação de serviços de telefonia, transporte, seguro. Neste sentido: GOMES, Orlando. Contratos. $26^{\mathrm{a}}$ Ed. Rio de Janeiro: Forense, 2008, p. 141. "Para haver contrato de adesão no exato sentido da expressão, não basta que a relação jurídica se forme sem prévia discussão, aderindo uma das partes à vontade da outra. Muitos contratos se estipulam desse modo sem que devam ter essa qualificação. A predominância eventual de uma vontade sobre a outra e até mesmo a determinação unilateral do conteúdo do contrato não constituem novidade. Sempre que uma das partes se encontra em relação à outra numa posição de superioridade, ou, ao menos, mais favorável, é normal que queira impor sua vontade, estabelecendo as condições do contrato. A cada momento isso se verifica sem que o fato desperte a atenção dos juristas, justo porque essa adesão se dá sem qualquer constrangimento se a parte pode dispensar o contrato. $O$ que caracteriza o contrato de adesão propriamente dito é a circunstância de que aquele a quem é proposto não pode deixar de contratar, porque tem necessidade de satisfazer a um interesse que, por outro modo, não pode ser atendido. Assim, quem precisa viajar, utilizando determinado meio de transporte, há de submeter-se às condições estipuladas pela empresa transportadora, pois não lhe resta outra possibilidade de realizar o intento. A alternativa é contratar ou deixar de viajar, mas se a viagem é necessária, está constrangido, por essa necessidade, a aderir às cláusulas fixadas por aquele que pode conduzi-lo".

${ }^{75}$ MARTINS, Pedro A. Batista. "A Arbitragem nas Sociedades de Responsabilidade Limitada", 2003, p. 17, "Em concreto, o estatuto social transcende as raias dos chamados contratos de (por) adesão, pois situado em outra latitude jurídica, a dos vínculos plurilaterais. Dita ele as relações entre sócios e entre estes e a companhia, onde não se eleva a unilateralidade, a fraqueza e a hipossuficiência registradas nos contratos típicos de adesão".

${ }^{76}$ MOREIRA, Daniela Bessone Barbosa. "A Convenção Arbitral em Estatutos e Contratos Sociais". In: ALMEIDA, Ricardo Ramalho (coord.). Arbitragem Interna e Internacional: Questões de Doutrina e da Prática. São Paulo: Renovar, 2003, p. 375; FLAKS, Luís Lória. "A arbitragem na reforma da lei das Sociedades Anônimas". Revista de Direito Mercantil Industrial, Econômico e Financeiro, vol. 131, ano XLII, 2003, p. 103, "o contrato de adesão se caracteriza, em regra, pela bilateralidade da relação jurídica, ou seja, pela existência de interesses distintos das partes contratantes, diferentemente do que acontece em uma 
normalmente encontrados nas relações consumeristas em que há um fornecedor de bens ou serviços e um aderente consumidor ${ }^{77}$. Nestes casos, a Lei de Arbitragem exigiu que o aderente deveria concordar expressamente com a cláusula compromissória inserida no contrato de adesão, assinando-a de modo $\operatorname{apartado}^{78}$. No caso das relações societárias, não nos parece que a comparação ao contrato de adesão seja a melhor interpretação ${ }^{79}$.

Todas as considerações feitas acima a respeito dos novos acionistas se aplicam ao caso dos acionistas ausentes da deliberação assemblear que aprovar a inclusão de cláusula compromissória estatutária. Caso diferente é o dos acionistas dissidentes da deliberação, uma

sociedade. Ocorre que os interesses dos acionistas de uma companhia, independentemente de seu objeto social, convergem necessariamente para um mesmo fim: a obtenção de lucro pela sociedade".

77 O artigo 54 do Código de Defesa do Consumidor define contrato de adesão como: "aquele cujas cláusulas tenham sido aprovadas pela autoridade competente ou estabelecidas unilateralmente pelo fornecedor de produtos ou serviços, sem que o consumidor possa discutir ou modificar substancialmente seu conteúdo".

${ }^{78}$ Artigo $4^{\circ}, \S 2^{\circ}$ da Lei da Arbitragem: Nos contratos de adesão, a cláusula compromissória só terá eficácia se o aderente tomar a iniciativa de instituir a arbitragem ou concordar, expressamente, com a sua instituição, desde que por escrito em documento anexo ou em negrito, com a assinatura ou visto especialmente para essa cláusula. ${ }^{79}$ MARTINS, Pedro Batista. Arbitragem no Direito Societário. São Paulo: Quartier Latin, 2012, p. 119, “ $E$ descabida a afirmação de que os estatutos sociais têm a natureza de contrato de adesão como fundamento jurídico para afastar os efeitos da cláusula compromissória estatutária àqueles que com ela não consentiram expressamente. (...) Trata-se, ao meu ver, de argumento improcedente dada a inadequada aplicação da previsão legal, claramente, de caráter restritivo; logo, voltada a uma estrita esfera da relação jurídica moderna. Relação essa que se restringe aos negócios tipicamente consumeristas". O acionista pode não ter poder de barganha com a companhia em relação às disposições estatutárias vigentes da companhia. Ocorre, entretanto, que, diferentemente de um consumidor, o acionista, ainda que não consiga discutir os termos do estatuto, tem sofisticação suficiente para escolher e assumir o risco de se vincular a todas as disposições estatutárias das companhias nas quais optou por investir. Neste sentido, SHELL, G. Richard. "Arbitration and Corporate Governance". North Carolina Law Review, vol. 67, 1989, pp. 549-550, "the passive nature of public shareholder ownership assures that many shareholders will be unaware of a charter arbitration provision and, even if aware of it, will have accepted arbitration without meaningful bargaining. These shareholders may argue that the charter of a public corporation is a 'contract of adhesion' and should not be enforced. There can be little doubt that, if the charter is a contract at all, it is adhesive in character. Public shareholders have no meaningful choice when presented with the option of buying the corporation's stock: either they buy the stock with the existing charter or they do not buy the stock at all. The corporation does not bargain over the content of the charter except in highly unusual circumstances. (...) Unconscionability is most often found in the consumer context and operates to relieve unwary, disadvantaged consumers from onerous contract terms imposed by more powerful business parties. People who have sufficient funds and sophistication to invest in the equity securities of individual corporations do not fit this mold comfortably and may, in many cases, be quite wealthy. Thus, although, such investors may not have bargaining power equal to their corporations', they are probably sophisticated enough to bear the risk of being bound by otherwise legal provisions in a corporate charter". Ainda, VALÉRIO, Marco Aurélio Gumieri. "A arbitragem nas sociedades anônimas: vinculação dos acionistas novos, ausentes, dissidentes e administradores à cláusula compromissória estatutária. Inclusão do $\S 3^{\circ}$ ao art. 109 pela Lei 10.303/2001". Revista de Direito Mercantil Industrial, Econômico e Financeiro, vol. 139, 2005, p. 170, "a CVM incumbe-se da tarefa de protegê-lo. Emprega, para tanto, um conjunto de princípios e regras concebidos para atender às especificidades da sociedade anônima, a exemplo do princípio da publicidade, consagrado pela obrigatoriedade de divulgação de informações relevantes e pelo registro de ofertas públicas; ou, ainda, do princípio da isonomia, garantido proibição do uso de informações privilegiadas". Ademais, MAKANT, Barbara. "A arbitrabilidade subjetiva nas sociedades anônimas". Revista de Arbitragem e Mediação, vol. 4, 2005, pp. 82 e ss., "a circunstância descrita acima não se adequa à situação de um acionista novo perante a sociedade, que a ela se associa por livre e espontânea vontade, além do que as cláusulas estatutárias são sempre definidas de acordo com a decisão da maioria dos acionistas e não em razão da vontade unilateral de um contratante". 
vez que, em relação a eles, existe expressa manifestação de vontade no sentido contrário à adoção da arbitragem como mecanismo de solução de controvérsias. Neste caso, cumpre reiterar a finalidade instrumental do princípio majoritário de viabilizar a condução dos negócios sociais ${ }^{80}$. Tendo em vista a impossibilidade de deliberações unânimes para a tomada de decisões, entende-se que a posição da companhia se expressa através do voto dos acionistas que representam a maioria do capital social reunidos em assembleia ${ }^{81-82}$, salvo se quórum maior não for exigido por lei ou pelo estatuto, sendo a assembleia geral o órgão primário da corporação e última instância decisória ${ }^{83}$.

O investidor, ao ingressar em uma sociedade, deve ter conhecimento das normas societárias e do conteúdo dos atos constitutivos da sociedade na qual ingressa e, portanto, deve também aceitar se submeter às regras legais sobre governança, incluindo as deliberações por maioria ${ }^{84}$. Em decorrência disto, acionistas ausentes e mesmo dissidentes da deliberação assemblear que aprovou a inserção de cláusula compromissória deveriam também estar vinculados à arbitragem.

Não obstante toda a discussão acerca da extensão subjetiva da cláusula compromissória estatutária, a Lei 13.129 de 26 de maio de 2015 reformou a Lei das S.A. e,

${ }^{80}$ PELA, Juliana Krueger. "Notas sobre a eficácia da cláusula compromissória estatutária”. Revista de Direito Mercantil Industrial, Econômico e Financeiro, vol. 126, ano XLI, 2002, pp. 134-135.

${ }^{81}$ BULGARELLI, Waldirio. “Deliberar não deliberar é deliberar?”. In: Questões de Direito Societário. São Paulo: Revista dos Tribunais, 1983, p. 86, “O princípio de deliberação pela maioria veio a ser adotado após longa e tortuosa história, em que se procurou formas e modos de ajustar a vontade de todos para se alcançar sempre a unanimidade o que, revelando-se impossível, levou a se admitir primeiro, como ficção, que a vontade da maioria era a vontade de todos, e posteriormente, a considerar efetivamente que a vontade da maioria representa a vontade da sociedade". FLAKS, Luís Lória. "A arbitragem na reforma da lei das Sociedades Anônimas". Revista de Direito Mercantil Industrial, Econômico e Financeiro, vol. 131, ano XLII, 2003 , p. 105.

${ }^{82}$ A análise da estrutura de poder na sociedade anônima não está no escopo do presente trabalho. Não obstante, cabe destacar que, apesar do fato de que a aplicação do princípio da maioria nas deliberações sociais foi a forma de operacionalizar as decisões, uma vez que a unanimidade seria inviável, há de se reconhecer que há uma predominância das decisões do acionista controlador. Neste sentido, GUERREIRO, José Alexandre Tavares. "Sociologia do Poder na Sociedade Anônima". Revista de Direito Mercantil Industrial, Econômico e Financeiro, vol. 77, ano XXIX, 1990, p. 52, "No que tange ao poder do acionista controlador, tem ele foro próprio, que vem a ser a assembleia geral em que seu voto prepondera, mas é inegável que o exercício daquele poder se verifica também fora da assembleia geral, mediante a utilização de uma força informal, insuficientemente normatizada, que se traduz na fórmula legislada de 'dirigir as atividades sociais e orientar o funcionamento dos órgãos da companhia"".

${ }^{83}$ COMPARATO, Fábio Konder; SALOMÃO FILHO, Calixto. O poder de controle na sociedade anônima,

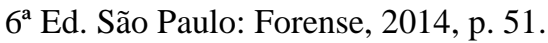

${ }^{84}$ ENEI, José Virgílio Lopes. “A arbitragem nas sociedades anônimas”. Revista de Direito Mercantil Industrial, Econômico e Financeiro, vol. 129, 2003, p. 163, “A decisão por maioria, portanto, não se dá à revelia do acionista dissidente, mas decorre de sua prévia e voluntária submissão às regras do jogo. E essa sua prévia e voluntária aceitação das regras corporativas que dá legitimidade à assembleia, conferindo-lhe poderes para deliberar em nome de todos os acionistas, e a todos vincular, ainda que por maioria de votos"; MARTINS, Pedro A. Batista. “A arbitragem no Direito Societário”. Revista de Arbitragem e Mediação, vol. 39, 2013, p. 58. 
dentre outros pontos, pretendeu resolver referida controvérsia ao inserir o artigo 136- $\mathrm{A}^{85}$, estabelecendo (i) quórum qualificado de maioria das ações com direito a voto para deliberação sobre a inserção de clausula compromissória; (ii) previsão expressa sobre a vinculação de todos os acionistas; e (iii) direito de recesso aos acionistas dissidentes, salvo quando a convenção de arbitragem for condição para admissão dos valores mobiliários da companhia à negociação em segmento de listagem que exija dispersão acionária mínima de 25\% (vinte e cinco por cento) das ações de cada espécie, ou quando a convenção seja incluída em companhia aberta cujas ações tenham liquidez e dispersão, nos termos do artigo 137, II, alíneas "a" e "b".

A solução legislativa não passou ilesa a críticas da doutrina. Para Rodrigo Tellechea, por exemplo, o legislador foi econômico ao falar apenas na deliberação para "inserção" ou “inclusão" da convenção de arbitragem estatutátia como hipótese de exercício do direito de recesso. $\mathrm{O}$ autor defende que o recesso deveria abranger mudanças na cláusula compromissória, incluindo nos casos de "alterações relevantes na sua redação, linguagem, conteúdo ou formato" que resultem em nova cláusula e de supressão da mesma ${ }^{86}$. De outro lado, para alguns autores, o direito de recesso foi uma opção bastante dura para a sociedade, que deve arcar com os pagamentos devidos aos acionistas que exerceram o recesso, com base em uma deliberação que, contrariamente às outras hipóteses de exercício do direito de recesso, não gera, a princípio, perdas para os acionistas ${ }^{87}$.

Apesar do questionamento sobre a opção do legislador, o artigo 136-A pretendeu resolver a discussão acerca da arbitrabilidade subjetiva da cláusula compromissória

\footnotetext{
${ }^{85}$ Apesar da mudança legislativa que, de certa forma, encerrou a discussão sobre a vinculação dos acionistas novos, ausentes e dissidentes da deliberação à arbitragem, persistem divergências doutrinárias sobre o tema. Em 25 de abril de 2018, a FIESP organizou um Debate sobre a Constitucionalidade do Artigo 136-A da Lei das S.A., que contou com a participação de Jorge Lobo, José Alexandre Tavares Guerreiro, Modesto Carvalhosa, Nelson Eizirik e Marcelo Huck. Em referido evento, Modesto Carvalhosa reafirmou todos os argumentos já expostos neste trabalho em relação à cláusula compromissória estatutária e sua vinculação a acionistas ausentes, dissidentes e novos, confirmando a necessidade de adesão expressa. No mesmo sentido se manifestou Jorge Lobo. De outro lado, Nelson Eizirik e José Alexandre Tavares Guerreiro se manifestaram no sentido da constitucionalidade do artigo 136-A da Lei das S.A. e da necessidade da vinculação da totalidade dos acionistas, sob pena de se inviabilizar a condução dos negócios sociais e da solução de disputas, uma vez que um mesmo caso poderia ser levado à arbitragem e ao judiciário e ter decisões distintas.

${ }^{86}$ TELLECHEA, Rodrigo. Arbitragem nas Sociedades Anônimas: Direitos Individuais e Princípio Majoritário. São Paulo, Quartier Latin, 2016, p. 465.

${ }^{87}$ Considerando que a arbitragem foi declarada constitucional e é tida como método jurisdicional de solução de conflitos, não haveria prejuízo aos acionistas para justificar um direito de recesso. Neste sentido, VILELA, Marcelo Dias Gonçalves; SALUM, Rafaella Coscarelli. "Note: Parties not indicated, Court of Justice of the State of São Paulo, Case No. 2031444-61.2016.8.26.0000, 14 December 2016”. Revista Brasileira de Arbitragem, vol. XIV, issue 55, 2017, p. 128; FRANZONI, Diego. Arbitragem Societária. São Paulo: Editora Revista dos Tribunais (Coleção Liebman, coordenação Teresa Arruda Alvim Wambier e Eduardo Talamini), 2015, pp. 135 e ss.
} 
estatutária, estatutária, ficando determinada a vinculação de todos os acionistas à disposição. A lei estabeleceu um prazdo de 30 (trinta) dias contados da deliberação social para que a deliberação tenha eficácia ${ }^{88}$. A controvérsia de vinculação dos acionistas ainda remanesce, porém, em relação aos casos anteriores à reforma da lei.

O histórico da evolução do instituto no país justifica a expansão do uso da arbitragem e demonstra a clara tendência legislativa de incentivar esse desenvolvimento, em especial para litígios societários, estabelecendo, inclusive, o juízo arbitral obrigatório para algumas companhias abertas em disputa decorrentes de matérias estatutárias. A nosso ver, esse rápido crescimento talvez tenha deixado de lado algumas dúvidas quanto à arbitragem estatutária, como as formas de integração de múltiplas partes no procedimento, os efeitos de sentenças na esfera jurídica daqueles que não integraram o processo, o prejuízo para fins de fiscalização da gestão e, sobretudo, as consequências da confidencialidade desses litígios, tema objeto desta pesquisa.

\footnotetext{
${ }^{88}$ Sobre o artigo 136-A, da Lei das S.A.: PACHIKOSKI, Silvia Rodrigues P.; MEDINA SALLA, Ricardo. "Novas Perspectivas sobre a Arbitragem e o Direito Societário". In: HOLANDA, Flávia; MEDINA SALLA, Ricardo (coords.). A Nova Lei da Arbitragem Brasileira, $1^{a}$ Ed. São Paulo: IOB SAGE, 2015, pp. 212 e ss., "entendemos que o sócio dissidente deve, a princípio, submeter-se à nova disposição contratual que incluiu a convenção de arbitragem. (...) O prazo visa a dar oportunidade à companhia de rever sua decisão caso ocorra uma resistência de grandes proporções, ou seja, se muitos acionistas exercerem o seu direito de recesso, a ponto de inviabilizar a continuidade da medida corporativa adotada". Na jurisprudência, destacamos o processo TJSP, Agravo de Instrumento $\mathrm{n}^{\circ}$ 2031444-61.2016.8.26.0000, 2a Câmara Reservada de Direito Empresarial, Des. Relator Caio Marcelo Mendes de Oliveira, julgado em 14 de dezembro de 2016. Trata-se de agravo de instrumento interposto por Irmãos Parasmo S.A. Indústria Mecânica, doravante denominada "Companhia", em face de Zara Sartório Parasmo, Eloísa Sartório Parasmo, Mônica Sartório Parasmo e Rogério Sartório Parasmo contra decisão que suspendeu a validade e a eficácia de deliberação assemblear da Companhia que modificou o estatuto social para fins de inclusão de cláusula compromissória. O julgamento do agravo confirmou o entendimento da juíza da $1^{\mathrm{a}}$ instância no sentido de que (i) a modificação do estatuto social seria forma de abuso do poder de controle, pois, frente à dificuldade financeira da Companhia, fazer esta arcar com os pagamentos devidos aos acionistas que exercerem direito de recesso seria contrário ao interesse social e (ii) a alteração teria sido conduzida em momento de grande divergência entre os acionistas, dada a existência de diversos processos em trâmite entre as partes, de modo que a escolha da arbitragem poderia inviabilizar o acesso à justiça. Marcelo Dias Gonçalves Vilela e Rafaella Coscarelli Salum, ao comentarem o caso, criticam a intervenção do Poder Judiciário na vida da sociedade, que julga embasado na premissa de que a deliberação pela convenção arbitral estatutária seria contrária ao interesse social, dada a situação financeira da companhia, e de que os custos da arbitragem poderiam inviabilizar o acesso à justiça. Neste sentido, VILELA, Marcelo Dias Gonçalves; SALUM, Rafaella Coscarelli. "Note: Parties not indicated, Court of Justice of the State of São Paulo, Case No. 2031444-61.2016.8.26.0000, 14 December 2016”. Revista Brasileira de Arbitragem, vol. XIV, issue 55, 2017, pp. 129-130.
} 


\section{Plano de trabalho}

Para fins de organização, dividimos o trabalho em duas partes. Na primeira, faremos um apanhado teórico sobre a relevância da informação para o mercado e as justificativas que motivaram a intervenção regulatória estatal sobre a matéria, bem como seus efeitos sobre os investidores. Neste segmento do trabalho, iremos explorar ainda as principais normas de divulgação de informações para companhias abertas no Brasil e em quais delas se encaixaria a divulgação acerca de procedimentos arbitrais, tendo em vista que não há nenhuma disposição direta e específica sobre o tema.

Na segunda parte, iremos refletir sobre a suficiência do regime de divulgação no que tange à participação da companhia em arbitragens. Para tanto, discutiremos a relação da confidencialidade com a arbitragem, que não é de necessariedade, mas de mera opção das partes e, a partir disso, trataremos dos questionamentos envolvendo a arbitragem confidencial em litígios societários, internos às companhias abertas. Por fim, tentaremos apresentar algumas propostas para tornar o sistema de divulgação de informações a respeito da arbitragem mais robusto e mitigar - ainda que parcialmente - as dúvidas acerca da utilização da arbitragem no seio das sociedades. 


\section{CONCLUSÃO}

Partindo da premissa de que a arbitragem é provavelmente o método mais adequado para a solução de litígios societários envolvendo companhias abertas, justamente pela complexidade dos temas em disputa, da potencial pluralidade de partes e da maior sofisticação dos julgadores, que podem ser escolhidos a dedo, é preciso refletir sobre as peculiaridades desse método para que ele não se torne incompatível com as obrigações às quais as companhias abertas estão sujeitas, como a obrigação de disclosure.

A confidencialidade, ainda que não inerente ao procedimento arbitral, costuma ser contratada pelas partes, em especial no âmbito empresarial, mas é mitigada em prol de outros interesses em diversos casos, como em arbitragens envolvendo a administração pública, empresas em recuperação judicial ou no caso da presença do dever de divulgar ao mercado.

Este trabalho sustentou que a informação é essencial para o funcionamento do mercado e que, independentemente do perfil do investidor, seria pouco razoável esperar a realização de investimentos sem nenhum conhecimento acerca dos emissores e dos valores emitidos. Argumentamos ainda que a intervenção estatal regulando o assunto, ainda que questionável quanto a sua necessidade, conteúdo e efetividade, é a solução mais razoável e intuitiva para tornar o acesso à informação mais compreensível, democrático e comparável, reduzindo a assimetria de informações. Considerando, de outro lado, que os investidores, ainda que mais sofisticados, têm limitações cognitivas de compreensão e de análise do grande volume de informações disponibilizado, a regulação deve ser restrita a um núcleo essencial focado em dados úteis para a avaliação dos valores mobiliários emitidos e para a fiscalização da gestão dos emissores, assumindo, portanto, papel relevante para fins de governança.

No país, a regulação prevê a divulgação de uma extensa lista de informações periódicas e eventuais. $\mathrm{O}$ escopo do nosso trabalho não foi refletir sobre a suficiência do regime como um todo ou propor alterações, incluindo eventuais reduções do nível de informação, mas nos limitamos a analisar se as disposições aplicáveis à divulgação de informações relativas a procedimentos arbitrais seria satisfatória, tendo em vista a multiplicidade de agentes interessados nos resultados financeiros e reputacionais de tais procedimentos. Baseado nesta análise, sustentamos que as normas aplicáveis ao tema são insuficientes para assegurar o acesso a um conteúdo mínimo de informações, tendo em vista 
o direito de fiscalização dos acionistas, o dever de informar ao mercado e a função do sistema de disclosure. Assim, defendemos uma mitigação ampla da confidencialidade da arbitragem estatutária nas companhias abertas, no sentido de que deveria ser obrigatória a divulgação do início de qualquer procedimento arbitral, com a indicação das partes, câmara, valor envolvido, objeto e sentença. Reconhecemos, no entanto, que qualquer intervenção para determinar essa "divulgação ampla" de informações, além dos custos de implementação, fiscalização e monitoramento, certamente enfrentaria grande resistência. Deste modo, fizemos um esforço para identificar um padrão de litígios societários decorrentes da convenção estatutária que deveriam ser de divulgação obrigatória, afastando-se do conceito de "relevância" da ICVM 358, que se manteria como regra geral para os demais casos. Neste sentido, entendemos que disputas envolvendo o acionista controlador e os administradores devem ser objeto de divulgação obrigatória, tendo em vista: (i) a função do sistema regulatório de divulgação de informações para fins de redução de custos de agência, melhoria na fiscalização da gestão e desestímulo às práticas ilegais e contrárias ao interesse social; (ii) o papel especial assumido por cada um desses indivíduos na administração da companhia e do patrimônio dos demais acionistas, incluindo os seus deveres fiduciários; e (iii) o impacto positivo na melhoria da governança das companhias com essa divulgação funcionando como método de fiscalização e monitoramento. Nestes casos, tanto administrador quanto controlador deveriam ser obrigados a informar a companhia a respeito de arbitragens societárias nas quais estivessem envolvidos, sendo que, para este último, entendemos ser necessária intervenção regulatória para incluir essa obrigação específica.

Da mesma forma que as disputas societárias podem ser relevantes (e, na maior parte do caso são) para os acionistas e o mercado, as disputas da companhia com terceiros, assim entendidas as disputas não decorrentes de convenção estatutária, muito provavelmente também terão impacto na precificação dos valores mobiliários emitidos ou em aspectos de natureza outra que não financeira, como reputacional, de governança ou operacional. Para esses casos, apesar de fora do nosso escopo de trabalho, pontuamos que também é importante refletir sobre os impactos da confidencialidade e sobre a suficiência da regulamentação vigente para lidar com esse tipo de litígio.

O presente trabalho tem a consciência de que as propostas sugeridas estão longe de resolver os problemas decorrentes da confidencialidade da arbitragem nas companhias abertas. Além da relativização do sigilo, a arbitragem societária estatutária, tanto para companhias abertas quanto fechadas, ainda tem um longo caminho para evoluir nos aspectos 
processuais, de modo a assegurar a ciência e a participação daqueles que serão afetados pela sentença e, portanto, devem ter resguardado o seu direito ao contraditório. No entanto, acreditamos que as sugestões propostas podem, de certa forma e em alguma medida, mitigar o questionamento da arbitragem no âmbito das relações intra-companhia e servir de ponto de partida para uma maior reflexão acerca da relativização da confidencialidade em outros tipos de procedimentos arbitrais. 


\section{BIBLIOGRAFIA}

\section{a. Livros E Artigos}

ADAMEK, Marcelo Vieira von. Abuso de minoria em direito societário. São Paulo: Malheiros, 2014.

AGUIAR, Danilo Augusto Barboza de. "Proteção aos acionistas minoritários das sociedades anônimas abertas como forma de promover o desenvolvimento do mercado de capitais nacional”. Revista de Direito Bancário, do Mercado de Capitais e da Arbitragem, $\mathrm{n}^{\circ} 22$, 2003.

AKERLOF, George. The Market for "Lemons": Quality Uncertainty and the Market Mechanism. The Quarterly Journal of Economics, vol. 84, n 3, 1970.

ARAÚJO ARAGÃO, Lindenberg; SOUSA CAVALCANTE, Danival. "Qualidade das Informações do Formulário de Referência nas Empresas Brasileiras Listadas no Novo Mercado da BM\&FBovespa". RACE- Revista de Administração, Contabilidade e Economia, vol. 13, issue 3, 2014, pp. 1089-1118.

ARMELIN, Donaldo. "Arbitragem e o Novo Código de Processo Civil". Revista de Arbitragem e Mediação, vol. 28, 2011.

ASCARELLI, Tullio. "O contrato plurilateral". Problemas das sociedades anônimas e direito comparado. $2^{\text {a }}$ Ed. São Paulo: Saraiva, 1969.

. "Vícios das deliberações assembleares - direitos individuais dos acionistas, prescrição". Problemas das sociedades anônimas e direito comparado. São Paulo: Quórum, 2008.

BAGNER, Hans. "Confidentiality - A Fundamental Principle in International Commercial Arbitration?". Journal of International Commercial Arbitration. Kluwer Law International, vol. 18, issue 2, 2001.

BAINBRIDGE, Stephen M. "Mandatory Disclosure: a Behavioral Analysis". University of Cincinnati Law Review, vol. 68, 2000. 
BAPTISTA, Luiz Olavo. Confidencialidade na arbitragem. In: V Congresso do Centro de Arbitragem Comercial - Intervenções. Lisboa: Almedina, 2012.

BARBOSA FILHO, Marcelo Fortes. Sociedade Anônima Atual: Comentários e Anotações às Inovações trazidas pela Lei n. 10.303/ ao texto da Lei n. 6404/76. São Paulo: Atlas, 2004.

BASILIO, Ana Tereza; LINS, Thiago. “A relativização da confidencialidade na arbitragem; companhias abertas”. Revista de Arbitragem e Mediação, vol. 49, 2016.

BEAVER, William H. “Market Efficiency”. The Accounting Review, vol. LVI, n 1, 1981.

BENCKE, Carlos Alberto. Acionista Minoritário na Sociedade Anônima. Porto Alegre: Livraria do Advogado, 2003.

BENSTON, George. "The Value of the SEC's Accounting Disclosure Requirements". Accounting Review, vol. 44, n 3, 1969.

"Required Disclosure and the Stock Market: An Evaluation of the Securities Exchange Act of 1934”. The American Economic Review, vol. 63, n 1, 1973.

BERNARDES, Lucas Petri. Dever de diligência dos administradores de sociedades anônimas. Dissertação (mestrado em Direito) - Programa de Pós-graduação em Direito Comercial da Faculdade de Direito da Universidade de São Paulo (orientadora Professora Doutora Juliana Krueger Pela). São Paulo, 2014.

BERTOLDI, M. Marcelo. Reforma da Lei das Sociedades Anônimas - Comentários à Lei 10.303 de 31 de outubro de 2001. $2^{\text {a }}$ Ed. São Paulo: Editora Revista dos Tribunais, 2002 .

BEVILAQUA, Clovis. Comentários ao Código Civil, vol. 4. São Paulo: Francisco Alves, 1958.

BLACK, Bernard S. "The Core Institutions that Support Strong Securities Markets". Stanford Law School, John M. Olin Program in Law and Economics, Working paper $n^{\circ}$ 200, 2000. Disponível em <https://papers.ssrn.com/sol3/papers.cfm?abstract_id=231120>, acesso em dezembro de 2018. 
; DE CARVALHO, Antonio Gledson; GORGA, Érica. A Governança

Corporativa das Empresas Brasileiras com Controle Privado Nacional, 2009.

Disponível em <http://conhecimento.ibgc.org.br/Paginas/Publicacao.aspx?PubId=20715>, acesso em novembro de 2018.

BLACKABY, Nigel; PARTASIDES, Constantine; REDFERN, Alan; HUNTER, J. Martin. International Arbitration. Oxford University Press, 2009.

BORN, Gary B. International Commercial Arbitration. Kluwer Law International, 2009.

BRACKER, Julie K., SODERQUIST, Larry D. "Arbitration in the Corporate Context". Columbia Business Law Review, $\mathrm{n}^{\circ}$ 1, 2003.

BRAGHETTA, Adriana. "Notas sobre a confidencialidade na arbitragem". Revista do Advogado - AASP, n 119, ano XXXIII, 2013.

BRANDEIS, Louis. Other People's Money and How the Bankers Use It. New York: Frederik A. Stokes Company, 1914.

BULGARELLI, Waldirio. “Deliberar não deliberar é deliberar?”. In: Questões de Direito Societário. São Paulo: Revista dos Tribunais, 1983.

BUSCHINELLI, Gabriel Saad Kik; BRESCIANI, Rafael Helou. “Aspectos Processuais da Ação de Responsabilidade do Controlador movida por Acionista Titular de Menos de 5\% do Capital Social (art. 246, §1, “b” da Lei 6.404/76)". In: YARSHELL, Flávio Luiz; PEREIRA, Guilherme Setoguti J. Processo Societário, vol. II. São Paulo: Quartier Latin, 2015.

CABRAL, Thiago Dias Delfino. "A mitigação da confidencialidade da arbitragem na recuperação judicial”. Revista Brasileira de Arbitragem, vol. XV, issue 57, 2018.

CAHALI, Francisco José. Curso de Arbitragem. São Paulo: Revista dos Tribunais, 2011.

CALMON, Eliana. “A arbitragem e o Poder Público”. Discurso proferido no I Seminário de Mediação e Arbitragem organizado pela OAB/SP em 21 de agosto de 2009. Revista de Arbitragem e Mediação, vol. 24, 2010. 
CAMINHA, Uinie. "Arbitragem como Instrumento de Desenvolvimento do Mercado de Capitais". In: VERÇOSA, Haroldo Malheiros Duclerc (org.). Aspectos da arbitragem institucional: 12 anos da Lei 9.307/1996. São Paulo: Malheiros, 2008.

CANTIDIANO, Luiz Leonardo. Reforma da Lei das S.A. Comentada. Rio de Janeiro: Renovar, 2002.

CARMONA, Carlos Alberto. “Arbitragem e Jurisdição”. Revista de Processo, vol. 58, 1990.

Arbitragem e Processo: Um Comentário à Lei ${ }^{\circ}$ 9.307/96, $3^{\mathrm{a}} \mathrm{Ed}$.

São Paulo: Atlas, 2009.

. "Em torno do árbitro". Revista Internacional de Arbitragem e

Conciliação, ano III, 2010.

. “Arbitragem e administração pública - primeiras reflexões sobre a

arbitragem envolvendo a administração pública". Revista Brasileira de Arbitragem, vol. XIII, issue 51, 2016.

CARNAÚBA, César Augusto Martins. “Adequação da arbitragem aos litígios envolvendo o Poder Público". Revista Brasileira de Arbitragem, vol. XV, issue 58, 2018.

CARON, David; CAPLAN, Lee (eds.). The UNCITRAL Arbitration Rules: A Commentary, $2^{\text {a }}$ Ed. Oxford: Oxford University Press, 2013.

CARREIRA AlVIM, J. E., Tratado Geral da Arbitragem Interno. Belo Horizonte: Mandamentos, 2000.

CARVALHAL-DA-SILVA, André; LEAL, Ricardo. Corporate Governance, Market Valuation and Dividend Policy in Brazil, 2003. Disponível em $<$ https://papers.ssrn.com/sol3/papers.cfm?abstract_id=477302>, acesso em novembro de 2018.

CARVALHOSA, Modesto. "Cláusula Compromissória Estatutária e Juízo Arbitral”. In: LOBO, Jorge (coord.). Reforma da Lei das Sociedades Anônimas: Inovações e Questões Controvertidas da Lei 10.303, de 31 de outubro de 2001. $1^{\text {a }}$ Ed. Rio de Janeiro: Forense, 2002 . 
; EIZIRIK, Nelson. A Nova Lei das S/A. São Paulo: Saraiva, 2002.

Comentários à Lei de Sociedades Anônimas (arts. 75 a 137), $6^{\mathrm{a}} \mathrm{Ed}$,

vol. 2. São Paulo: Saraiva, 2014.

Comentários à Lei de Sociedades Anônimas (arts. 138 a 205), $6^{\text {a }}$

Ed., vol. 3. São Paulo: Saraiva, 2014.

CEREZETTI, Sheila Christina Neder. “Artigo 4". In: CODORNIZ, Gabriela, PATELLA, Laura (coords.). Comentários à Lei do Mercado de Capitais - Lei n ${ }^{\circ}$ 6.385/76. São Paulo: Quartier Latin, 2015.

CHOI, Stephen J. “Regulating Investors Not Issuers: A Market-Based Proposal”. California Law Review, UC Berkeley Law and Economics (Working Paper 2000 - 1), vol. 88, issue 2, 2000. Disponível em <http://papers.ssrn.com/paper.taf?abstract_id=202049>, acesso em outubro de 2018.

; GUZMAN, Andrew T. "Portable Reciprocity: Rethinking the International Reach of Securities Regulation”. S. California Law Review, vol. 71, 1997.

COELHO, Eduardo de Melo Lucas. A formação das deliberações sociais. Coimbra: Coimbra Editora, 1994.

COFFEE, John C. "Market Failure and the Economic Case for a Mandatory Disclosure System”. Virginia Law Review (Fifty Years of Federal Securities Regulation: Symposium on Contemporary Problems in Securities Regulation), vol. 70, n 4, 1984.

COLLINS, Michael. "Privacy and Confidentiality in Arbitration Proceedings". Texas International Law Journal, vol. 30, 1995.

COMPARATO, Fábio Konder; SALOMÃO FILHO, Calixto. O poder de controle na sociedade anônima, $6^{\text {a }}$ Ed. São Paulo: Forense, 2014.

COOTER, Robert; ULEN, Thomas. Law and Economics. Harper Collings Publishers, 1988.

Law and Economics, $6^{\text {a }}$ Ed. Berkeley Law Books, 2016. 
CORAPI, Diego. "Arbitragem no Direito Societário Italiano". Revista de Arbitragem e Mediação, vol. 43, 2014.

COX, James D.; HILMAN, Robert W.; LANGEVOORT, Donald C. Securities Regulation: Cases and Materials. New York: Aspen Publishers, 2006.

CRETELLA NETO, José. "Quão sigilosa é a arbitragem?" Revista de Arbitragem e Mediação, vol. 25, ano 7, 2010.

DENOIX DE SAINT MARC, Valéry. "Confidentiality of Arbitration and the Obligation to Disclose Information on Listed Companies or During Due Diligence Investigations". Journal of International Arbitration, Kluwer Law International, vol. 20, issue 2, 2003.

DINAMARCO, Cândido Rangel. A arbitragem na teoria geral do processo. São Paulo: Malheiros, 2013.

; LOPES, Bruno Vasconcelos Carrilho. Teoria Geral do Novo

Processo Civil. São Paulo: Malheiros, 2016.

DOUGLAS, William O. Protecting the Investor. Yale Review, vol. XXIII, n 3, 1934.

DYCK, Alexander; ZINGALES, Luigi. "Private Benefits of Control: An International Comparison". The Journal of Finance, vol. 59, n² 2, 2004.

EASTERBROOK, Frank H. e FISCHEL, Daniel R. "Mandatory Disclosure and the Protection of Investors”. Virginia Law Review, vol. 70, n 669, 1984.

EIZIRIK, Nelson. "Regulação e auto-regulação do mercado de Valores Mobiliários". Revista de Direito Mercantil, Industrial, Econômico e Financeiro, vol. 48, 1982. . "Insider Trading e responsabilidade de administrador de companhia aberta”. Revista de Direito Mercantil, Industrial, Econômico e Financeiro, nº 50, 1983. ; GAAL, Ariádna B.; PARENTE, Flávia; HENRIQUES, Marcus de Freitas. Mercado de Capitais: Regime Jurídico, $3^{\text {a }}$ Ed. São Paulo: Renovar, 2011. "O sigilo previsto na arbitragem é prejudicial ao funcionamento do mercado de capitais? NÃO: aos fatos: solução rápida e eficiente para os conflitos 
empresariais, arbitragem preserva a transparência". Revista Capital Aberto. vol.10, $\mathrm{n}^{\circ}$ 120, 2013.

A Lei das S/A Comentada, $2^{a}$ Ed., vol. II. São Paulo: Quartier Latin, 2015.

A Lei das S/A Comentada, 2ª Ed., vol. III. São Paulo: Quartier Latin,

2015.

ENEI, José Virgílio Lopes. “A arbitragem nas sociedades anônimas”. Revista de Direito Mercantil Industrial, Econômico e Financeiro, vol. 129, 2003.

FAMA, Eugene F. "Efficient Capital Markets: A Review of Theory and Empirical Work". The Journal of Finance, vol. 25, $\mathrm{n}^{\circ} 2,1970$.

FAMA, Eugene F. "Efficient Capital Markets II". The Journal of Finance, vol. 46, n 5, 1991.

FERRELL, Allen. "The Case for Mandatory Disclosure in Securities Regulation Around the World”. Harvard Law and Economics Discussion Paper $\mathbf{n}^{\circ}$ 492, 2004. Disponível em $<$ https://ssrn.com/abstract=631221>, acesso em setembro de 2018.

FICHTNER, José Antonio; MANNHEIMER, Sergio Nelson; MONTEIRO, André Luis. “A Confidencialidade na Arbitragem: Regra Geral e Exceções”. Revista de Direito Privado, vol. 49, 2012.

FICHTNER, José Antonio; MANNHEIMER, Sergio Nelson; MONTEIRO, André Luís. Novos temas de arbitragem. Rio de Janeiro: Editora FGV, 2014.

FLAKS, Luís Lória. “A arbitragem na reforma da lei das Sociedades Anônimas". Revista de Direito Mercantil Industrial, Econômico e Financeiro, vol. 131, ano XLII, 2003.

FORTIER, Yves L. "The Occasionally Unwarranted Assumption of Confidentiality". Arbitration International, vol. 15, $\mathrm{n}^{\circ}$ 2, 1999.

FOX, Merritt B. "Required Disclosure and Corporate Governance". Law and Contemporary Problems, vol. 62, n 3, 1999. 
"Retaining Mandatory Securities Disclosure: Why Issuer Choice is Not Investor Empowerment”. University of Michigan Law School (Working Paper $\mathbf{n}^{\circ}$ 99-008), 1999. Disponível em <https://ssrn.com/abstract=155928>, acesso em julho de 2018 .

FRANZONI, Diego. Arbitragem Societária. São Paulo: Editora Revista dos Tribunais (Coleção Liebman, coordenação Teresa Arruda Alvim Wambier e Eduardo Talamini), 2015.

FRAZÃO, Ana. “Arbitragem, confidencialidade e transparência”. Jota, 2017. Disponível em <https://www.jota.info/opiniao-e-analise/colunas/constituicao-empresa-emercado/arbitragem-confidencialidade-e-transparencia-01112017>, publicado em 1 de novembro de 2017, acesso em novembro de 2018.

FRIAS, Angélica Ramos de. "Alcance subjetivo da cláusula compromissória na solução de conflitos societários e no âmbito do mercado de capitais". In: PENTEADO, Mauro Rodrigues; MUNHOZ, Eduardo Secchi (coords.). Mercado de capitais brasileiro doutrina, cases e materials. São Paulo: Quartier Latin, 2012.

FRIEND, Irwin; HERMAN, Edward S. "The SEC Through a Glass Darkly". The Journal of Business, vol. 37, $\mathrm{n}^{\circ}$ 4, 1964.

; WESTERFIELD, Randolph. "Required Disclosure and the Stock Market Regulation: Comment”. The American Economic Review, vol. 65, n 3, 1975.

GILSON, Ronald J.; KRAAKMAN, Reinier H. "The Mechanisms of Market Efficiency". Virginia Law Review, vol. 70, 1984.

GORGA, Érica. "O sigilo previsto na arbitragem é prejudicial ao funcionamento do mercado de capitais? SIM, nada a esconder: sistema judicial de discovery permite publicidade de investigação e aperfeiçoa governança”. Revista Capital Aberto, vol. 10, n 120, 2013.

"Arbitragem, governança corporativa e retrocesso no mercado de capitais brasileiro". Revista de Direito Empresarial, vol. 1, 2014.

GRAU, Eros Roberto. "Arbitragem e Contrato Administrativo". Revista Trimestral de Direito Público, vol. 32, 2000. 
GUERREIRO, José Alexandre Tavares; TEIXEIRA, Egberto Lacerda. Das sociedades anônimas no direito brasileiro, vol. 1. São Paulo: Bushatsky, 1979.

"Sobre o poder disciplinar da CVM". Revista de Direito Mercantil,

Industrial, Econômico e Financeiro, n ${ }^{4}$, ano XX, 1981.

. "O Conselho Fiscal e o Direito à Informação". Revista de Direito

Mercantil, Industrial, Econômico e Financeiro, n ${ }^{\circ}$ 45, ano XXI, 1982.

. "Sociologia do Poder na Sociedade Anônima". Revista de Direito

Mercantil Industrial, Econômico e Financeiro, vol. 77, ano XXIX, 1990.

Fundamentos da arbitragem do comércio internacional. São

Paulo, Saraiva, 1993.

GUILHERME, Luiz Fernando do Vale de Almeida. “As Novas Formas de Atuação do Advogado no Mundo Globalizado Empresarial - A Arbitragem no Mercado de Capitais”. In: VERÇOSA, Haroldo Malheiros Duclerc (org.). Aspectos da Arbitragem Institucional: 12 Anos da Lei 9.307/1996. São Paulo: Malheiros, 1998.

GUTTENTAG, Michael D. “An Argument for Imposing Disclosure Requirements on Public Companies”. Florida State University Law Review, vol. 32, n 1, 2004.

GU WEIXIA. "Securities Arbitration in China: a Better Alternative to Retail Shareholder Protection”. Northwestern Journal of International Law \& Business, vol. 33, issue 2, 2013.

HANOTIAU, Bernard. Complex Arbitrations: Multiparty, Multicontract, Multi-issue and Class Actions (International Arbitration Law Library). Kluwer Law International, 2005.

HATANAKA, Alex. "Limites da confidencialidade na arbitragem envolvendo sociedades por ações de capital aberto". Revista de Direito das Sociedades e dos Valores Mobiliários, vol. 3, 2016.

. "O poder público e a arbitragem após a reforma da Lei n. 9.307/1996”.

Revista Brasileira de Arbitragem, vol. XIII, issue 49, 2016. 
HERTIG, Gerard; KRAAKMAN, Reinier; ROCK, Edward. "Issuers and Investor Protection". In: KRAAKMAN, Reinier; HANSMANN, Henry, et al. The Anatomy of Corporate Law: A Comparative and Functional Approach, $2^{\text {a }}$ Ed. Londres: Oxford University Press, 2009.

HIRSHLEIFER, Jack. "The Private and Social Value of Information and the Reward to Inventive Activity”. The American Economic Review, vol. 62, n 4, 1971.

JARRELL, Gregg A. "The Economic Effects of Federal Regulation of the Market for New security Issues”. The Journal of Law \& Economics, vol. 24, n 3, 1981.

JENSEN, Michael C.; MECKLING, William H. "Theory of the Firm: Managerial Behaviour, Agency Costs and Ownership Structure”. Journal of Financial Economics, vol. 3, 1976.

J. X. CARVALHO DE MENDONÇA. Tratado de Direito Comercial Brasileiro, $5^{\text {a }}$ Ed., vol. IV. Rio de Janeiro: Freitas Bastos, 1954.

JÚDICE, José Miguel. “Anotações ao Acórdão Esso Australia Resources Limited and Others $V$. the Honourable Sidney James Plowman and Others". In: 100 Anos de Arbitragem: os Casos Essenciais Comentados. Coimbra: Coimbra Editora, 2016.

KITCH, Edmund W. “The Theory and Practice of Securities Disclosure”. Brooklin Law Review, vol. 61, 1995.

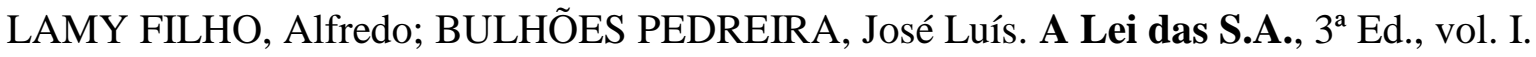
Rio de Janeiro: Renovar, 1997.

(orgs.). Direito das Companhias, vol. 1. Rio de Janeiro: Forense, 2009.

LAPORTA, Rafael; LOPEZ-DE-SILANES, Florencio; SHLEIFER, Andrei; VISHNY, Robert W. "Law and Finance”. Journal of Political Economy, vol. 106, n 1113, 1998.

LAZZARESCHI NETO, Alfredo Sérgio. "Sigilo nas arbitragens do Novo Mercado e direito de informação e fisscalização do acionista”. Revista de Direito Mercantil Industrial, Econômico e Financeiro, vol. 153/154, 2010. 
Lei das Sociedades por Ações Anotada, $5^{\mathrm{a}}$ Ed., vol. I. São Paulo:

Societatis Edições, 2017.

LEÃES, Luís Gastão Paes de Barros. Mercado de Capitais \& "Insider Trading". São Paulo: Editora Revista dos Tribunais, 1982.

. "Pactos parassociais. Natureza jurídica. Execução específica. Opção de recompra de participação societária e inexistência de infringência dos arts. 288 do CComercial e 1.372 do CC, por não configurar pacto leonino". Revista dos Tribunais., vol. 601, ano 74, 1985.

LEE, João Bosco. "O princípio da confidencialidade na arbitragem comercial internacional". In: LEE, João Bosco; VALENÇA FILHO, Clávio de Melo. Estudos de Arbitragem. Curitiba: Juruá, 2008.

LEITE, António Pinto. "Papel das Instituições de Arbitragem na Construção da Jurisprudência Arbitral - a Procura das Melhores Práticas”. Revista Brasileira de Arbitragem, vol. XI, issue 41, 2014.

LEMES, Selma Maria Ferreira. "Princípios e Origens da Lei de Arbitragem". Revista do Advogado, $n^{\circ}$ 51, 1997.

. "A arbitragem e os novos rumos empreendidos na Administração Pública: a empresa estatal, o Estado e a concessão de serviço público”. In: MARTINS, Pedro A. Batista; LEMES, Selma Maria Ferreira; CARMONA, Carlos Alberto. Aspectos fundamentais da Lei de Arbitragem. Rio de Janeiro: Forense, 1999.

“Arbitragem na concessão de serviços públicos: arbitrabilidade objetiva. Confidencialidade ou publicidade processual?". Revista de Direito Mercantil, Industrial, Econômico e Financeiro, vol. 134, ano XLIII, 2004.

Arbitragem em Números e Valores - Seis Câmaras - 8 anos Período de 2010 (jan./dez.) a 2017 (jan./dez.), 2018. Disponível em $<$ http://selmalemes.adv.br/publicacoes.asp?linguagem=Portugu\%EAs\&secao=Publica\%E7 $\% \mathrm{~F} 5$ es $\&$ subsecao $=\mathrm{T} \% \mathrm{~F} 3$ picos $\& \mathrm{acao}=$ Consulta\&especificacao $=$ Artigos $>, \quad$ acesso $\quad$ em novembro de 2018. 
LEVY, Daniel de Andrade. "Aspectos Polêmicos da Arbitragem no Mercado de Capitais". Revista Brasileira de Arbitragem, vol. 7, issue 27, 2010.

"Estudo comparado da arbitragem no mercado de capitais". Revista de Direito Mercantil Industrial, Econômico e Financeiro, vol. 155/156, 2010.

LEW, Julian M.; MISTELIS Loukas A.; KRÖLL, Stefan Michael. Comparative International Commercial Arbitration. Kluwer Law International, 2003.

LICATTI, Taissa Macaferri. "Novo Mercado: Influência e aspectos relacionados à inserção de Cláusula Compromissória Arbitral nos Estatutos Sociais”. In: VERÇOSA, Haroldo Malheiros Duclerc (org.). Aspectos da arbitragem institucional: 12 anos da Lei 9.307/1996. São Paulo: Malheiros, 2008.

LOSS, Louis. Fundamentals of Securities Regulation. Boston: Little, Brown and Company, 1983.

LUCENA, José Waldecy. Das Sociedades Anônimas - Comentários à Lei (arts. $1^{\circ}$ a 120), vol. I. Rio de Janeiro: Renovar, 2009.

LY, Filip de; BROZOLO, Luca G. Radicati di; FRIEDMAN, Mark. "Confidentiality in International Commercial Arbitration”. Revista de Arbitragem e Mediação, vol. 8, $\mathrm{n}^{\circ} 31$, 2011.

MAFFIOLETTI, Emanuelle Urbano; CEREZETTI, Sheila Christina Neder. Transparência e divulgação de informações nos casos de recuperação judicial de empresas. In: DE LUCCA, Newton; DOMINGUES, Alessandra Azevedo; ANTONIO, Nilva M. Leonardi (coords.). Direito Recuperacional II - Aspectos Teóricos e Práticos. São Paulo: Quartier Latin, 2012.

MAHONEY, Paul G. "Mandatory Disclosure as a Solution to Agency Problems". University of Chicago Law Review, vol. 62, 1995.

."The Exchange as Regulator". Virginia Law Review, vol. 83, n 3, 1997.

MAKANT, Barbara. "A arbitrabilidade subjetiva nas sociedades anônimas”. Revista de Arbitragem e Mediação, vol. 4, 2005. 
MANKIW, N. Gregory. Principles of Economics, 6 a Ed. South-Western Cengage Learning, 2011.

MARINO, Daniela Ramos Marques. "O status socii”. In: FRANÇA, Erasmo Valladão Azevedo e Novaes (coord.). Direito Societário Contemporâneo I. São Paulo: Quartier Latin, 2009.

MARQUES, José Frederico. Instituições de Direito Processual, vol. 5. Rio de Janeiro: Forense, 1960.

MARQUES, Ricardo Vilagra da Silva. “A eficácia da cláusula compromissória estatutária: uma questão (ainda) controvertida”. In: GUILHERME, Luiz Fernando do Vale de Almeida. Novos Rumos da Arbitragem no Brasil. São Paulo: Fiuza Editores, 2004.

MARTINS, Pedro A. Batista. “Cláusula Compromissória” In: MARTINS, Pedro A. Batista, LEMES, Selma M. Ferreira e CARMONA, Carlos Alberto. Aspectos fundamentais da lei de arbitragem. Rio de Janeiro: Forense, 1999.

MARTINS, Pedro A. Batista. "A Arbitragem nas Sociedades de Responsabilidade Limitada", 2003. Disponível em $<$ http://batistamartins.com/arbitragem-nas-sociedades-deresponsabilidade-limitada-2/>, acesso em novembro de 2018.

\section{Responsabilidade de Acionista Controlador: Considerações}

Doutrinárias e Jurisprudenciais. Palestra proferida na Associação dos Magistrados do Estado do Rio de Janeiro - AMAERJ, em 12 de julho de 2004. Disponível em $<$ http://batistamartins.com/wp-content/uploads/kalins-pdf/singles/responsabilidade-deacionista-controlador-2.pdf>, acesso em dezembro de 2018.

Arbitragem no Direito Societário. São Paulo: Quartier Latin, 2012. "A arbitragem no Direito Societário". Revista de Arbitragem e Mediação, vol. 39, 2013.

MEDAUAR, Odete. Direito Administrativo Moderno, $17^{\text {a }}$ Ed., São Paulo: Editora Revista dos Tribunais, 2013.

MEDINA, José Miguel Garcia. Novo Código de Processo Civil Comentado, $5^{\text {a }}$ Ed. São Paulo: Revista dos Tribunais, 2017. 
MISRA, Joyiyoti; JORDANS, Roman. "Confidentiality in International Arbitration". Journal of International Arbitration. Kluwer Law International, vol. 23, issue 1, 2006.

MORAES, Luiza Rangel de. "O regime de deliberações na sociedade limitada em confronto com o processo deliberativo na sociedade anônima". Revista de Direito Bancário, do Mercado de Capitais e da Arbitragem, vol. 21, 2003.

MOREIRA, Daniela Bessone Barbosa. "A Convenção Arbitral em Estatutos e Contratos Sociais”. In: ALMEIDA, Ricardo Ramalho (coord.). Arbitragem Interna e Internacional: Questões de Doutrina e da Prática. São Paulo: Renovar, 2003.

MOSES, Margaret S. The Principles and Practice of International Commercial Arbitration, 2a Ed. Cambridge: Cambridge University Press, 2012.

MUNHOZ, Eduardo Secchi. “Arbitragem e novo mercado”. In: MATTOS FILHO; VEIGA FILHO; MARREY JR.; QUIROGA ADVOGADOS (eds.). Arbitragem no Brasil. São Paulo: Impressão Régia, 2010.

NENOVA, Tatiana. "The Value of Corporate Votes and Control Benefits". Journal of Financial Economics, vol. 104, 2003.

NERY JUNIOR, Nelson; NERY, Rosa Maria de Andrade. Comentários ao Código de Processo Civil. São Paulo: Editora Revista dos Tribunais, 2015.

NEVES, Daniel Amorim Assumpção. Novo Código de Processo Civil Comentado, $2^{\text {a }}$ Ed. Salvador: Editora Juspodivm, 2017.

NOUSSIA, Kyriaki. Confidentiality in International Commercial Arbitration: A Comparative Analysis of the Position under English, US, German and French Law. Berlin: Springer, 2010.

OLIVEIRA, Gustavo Justino; FIGUEIROA, Caio Cesar. Arbitragem com o Poder Público: da confidencialidade à publicidade e transparência do procedimento arbitral, à luz da Lei Federal $\mathbf{n}^{\circ}$ 13.129/15, 2015. Disponível em <http://www.justinodeoliveira.com.br/\#!/artigos>, acesso em outubro de 2018. 
PACHIKOSKI, Silvia Rodrigues P.; MEDINA SALLA, Ricardo. "Novas Perspectivas sobre a Arbitragem e o Direito Societário". In: HOLANDA, Flávia; MEDINA SALLA, Ricardo (coords.). A Nova Lei da Arbitragem Brasileira, 1ª Ed. São Paulo: IOB SAGE, 2015.

PAREDES, Troy. "Blinded by the Light: Information Overload and its Consequences for Securities Regulation”. Washington University School of Law, Faculty Working Papers (paper $\mathrm{n}^{\circ}$ 03-02-02), 2003. Disponível em <http://ssrn.com/abstract=413180>, acesso em setembro de 2018.

PARENTE, Flávia. O Dever de Diligência dos Administradores de Sociedades Anônimas. Rio de Janeiro: Renovar, 2005.

PARGENDLER, Mariana; PRADO, Viviane Muller; BARBOSA JR., Alberto. “Cláusulas arbitrais no mercado de capitais brasileiro". Revista de Arbitragem e Mediação, $\mathrm{n}^{\circ} 40$, 2014.

PAULSSON, Jan; RAWDING, Nigel. "Trouble with Confidentiality". Arbitration International, vol. 11, $\mathrm{n}^{\circ}$ 3, 1995.

PELA, Juliana Krueger. "Notas sobre a eficácia da cláusula compromissória estatutária". Revista de Direito Mercantil Industrial, Econômico e Financeiro, vol. 126, ano XLI, 2002.

PEREIRA, Caio Mário da Silva. Instituições de Direito Civil, 22a Ed, vol. III. Rio de Janeiro: Forense, 2018.

PEREIRA, Guilherme Setoguti J. "Temos que Repensar a Confidencialidade das Arbitragens Societárias”. In: YARSHEL, Flávio Luiz; PEREIRA, Guilherme Setoguti J. (coords.). Processo Societário, vol. III. São Paulo: Quartier Latin, 2018.

Enforcement e Tutela Indenizatória no Direito Societário e no

Mercado de Capitais. São Paulo: Quartier Latin, 2018.

PINTO, José Emílio Nunes. “A Arbitrabilidade de Controvérsias nos Contratos com o Estado e Empresas Estatais”. Revista Brasileira de Arbitragem, vol. I, issue 1, 2004. “A confidencialidade na arbitragem". Revista de Arbitragem e Mediação, $n^{\circ}$ 6, 2005. 
PITTA, André Grünspun. O Regime de Informação das Companhias Abertas. São Paulo: Quartier Latin, 2013.

POSNER, Richard A. "Rational Choice, Behavioral Economics, and the Law". Stanford Law Review, vol. 50, 1997.

PROENÇA, José Marcelo Martins. Regime Jurídico do Uso de Informações Privilegiadas no Mercado de Capitais - Insider Trading. Tese de Doutorado. Faculdade de Direito da Universidade de São Paulo, 2004.

PRYLES, Michael. "Confidentiality”. The Leading Arbitrators Guide to International Arbitration, $3^{\text {a }}$ Ed. 2014.

PUGLIESE, Antonio Celso Fonseca; SALAMA, Bruno Meyerhof. "A Economia da Arbitragem: Escolha Racional e Geração de Valor”. Revista Direito GV, vol. 4, n ${ }^{\circ}$, São Paulo, 2008.

RAVANIDES, Christos A. "Arbitration Clauses in Public Company Charters: an Expansion of ADR Elysian fields or a descent into Hades?" The American Review of International Arbitration, vol. 18, $\mathrm{n}^{\circ}$ 4, 2007.

RODRIGUES, João Gaspar. "Publicidade, transparência e abertura na administração pública”. Revista de Direito Administrativo, vol. 266, Rio de Janeiro, 2014.

ROMANO, Roberta. "Empowering Investors: A Market Approach to Securities Regulation”. Yale Law Review, vol. 107, n 5, 1998.

ROSSI, Lívia. “Arbitragem na Lei das Sociedades Anônimas”. Revista de Direito Mercantil Industrial, Econômico e Financeiro, vol. 129, 2003.

ROTHMAN, Philip. "Pssst, please keep it confidential". Dispute Resolution Journal, vol. $49, \mathrm{n}^{\circ} 3,1994$.

SALOMÃO FILHO, Calixto. O novo direito societário, $4^{\mathrm{a}}$ Ed. São Paulo: Malheiros, 2011. "Breves Notas sobre Transparência e Publicidade na Arbitragem Societária". Revista de Arbitragem e Mediação, vol. 52, 2017. 
SAMPAIO CAMPOS, Luiz Antonio de. "Conselho de Administração e Diretoria". In: LAMY FILHO, Alfredo; BULHÕES PEDREIRA, José Luís (orgs.). Direito das Companhias, vol. 1. Rio de Janeiro: Forense, 2009.

SANTOS, Eliza Ferreira dos. "Os Direitos Essenciais dos Acionistas". Revista de Ciência Política, vol. 30, n 3, Rio de Janeiro, 1987.

SCALZILLI, João Pedro; SPINELLI, Luis Felipe. "A Racionalidade Econômica do Combate ao Insider Trading: Assimetria de Informação e Dano ao Mercado". Revista de Direito Mercantil, Industrial e Econômico, vol. 147, ano XLVI, 2007.

SCHIEHLL, Eduardo; DOS SANTOS, Igor Oliveira. "Ownership structure and composition of boards of directors: evidence on Brazilian publicly-traded companies". Revista de Administração da Universidade de São Paulo, vol. 39, n 4, 2004.

SELIGMAN, Joel. "The Transformation of Wall Street: A History of the Securities Exchange Commission and Modern Corporate Finance”. Houghton Mifflin, 1982. . "The historical need for a mandatory disclosure system". The Journal of Corporation Law, vol. 9, $\mathrm{n}^{\circ}$ 1, 1983.

SHELL, G. Richard. "Arbitration and Corporate Governance”. North Carolina Law Review, vol. 67, 1989.

SIMON, Carol J. "The Effect of the 1933 Securities Act on Investor Information and the Performance of New Issues”. The American Economic Review, vol. 79, n 3, 1989.

SIMON, Herbert A. "Theories of Decision-Making in Economics and Behavioral Science". The American Economic Review, vol. 49, n³, 1959.

SMIT, Hans. "Confidentiality in Arbitration". Arbitration International, vol. 11, $\mathrm{n}^{\circ} 3$, 1995.

STEIN, Raquel. Arbitrabilidade no Direito Societário. Rio de Janeiro: Renovar, 2014.

STETNER, Renato Parreira; PITOMBO, Eleonora Coelho. “A Convenção de Nova York: Ratificação pelo Brasil” In: GUILHERME, Luiz Fernando do Vale de Almeida (coord.). Novos Rumos da Arbitragem no Brasil. São Paulo: Fiuza Editores, 2004. 
STIGLER, George J. "The Economics of Information”. Journal of Political Economy, vol. $69, n^{\circ} 3,1961$. . "Public Regulation of the Securities Markets". The Journal of Business, vol. 37, $\mathrm{n}^{\circ}$ 2, 1964.

STOUT, Lynn A. "The Investor Confidence Game”. Brooklin Law Review, vol. 68, n², 2002.

STRAUBE, Frederico José. “A evolução da arbitragem no Brasil após a Lei 9307/1996”. Revista de Arbitragem e Mediação, vol. 50, 2016.

STUBER, Walter Douglas. “As Novas Regras Para Divulgação e Uso de Informações Sobre Atos ou Fatos Relevantes Relativos às Companhias Abertas Brasileiras". Revista de Direito Bancário e do Mercado de Capitais, vol. 16, 2002.

SUNDFELD, Carlos Ari; SOUZA, Rodrigo Pagani de. "Licitação nas Estatais: Levando a Natureza Empresarial a Sério”. Revista de Direito Administrativo, vol. 245, 2007.

SZTAJN, Raquel. "Regulação e o Mercado de Valores Mobiliários". Revista de Direito Mercantil Industrial, Econômico e Financeiro, vol. 135, ano XLIII, 2004.

TELLECHEA, Rodrigo. "Sobre a cláusula arbitral em companhias abertas: a questão da confidencialidade do procedimento". In: FRANÇA, Erasmo Valladão Azevedo e Novaes (coord.). Direito Societário Contemporâneo II. São Paulo: Malheiros, 2015.

Arbitragem nas Sociedades Anônimas: Direitos Individuais e Princípio Majoritário. São Paulo, Quartier Latin, 2016.

TOLEDO, Paulo Fernandes Campos Salles. "A Arbitragem na Lei das Sociedades Anônimas". In: CASTRO, Rodrigo R. Monteiro de; ARAGÃO, Leandro Santos de (orgs.). Sociedade Anônima 30 anos da Lei 6.404/76, $1^{\text {a }}$ Ed. São Paulo: Quartier Latin, 2007.

TONIN, Mauricio Morais. "Direito Patrimonial Disponível na Administração Pública: Tentativa de Definição”. Revista Brasileira de Arbitragem, vol. XV, issue 59, 2018.

TVERSKY, Amos; KAHNEMAN, Daniel. "Judgement under Uncertainty: Heuristics and Biases”. Science (New Series), vol. 185, n 4157, 1974. 
ULEN, Thomas S. "Rational Choice and the Economic Analysis of Law". Law \& Social Inquiry, vol. 19, $\mathrm{n}^{\circ}$ 2, 1994.

UNGER, Laura S. "Rethinking Disclosure in the Information Age: Can There be Too Much of a Good Thing?". Speech by SEC Commissioner, 2000. Disponível em <https://www.sec.gov/news/speech/spch387.htm>, acesso em outubro de 2018.

VALENÇA FILHO, Clávio. “Arbitragem e Contratos Administrativos”. Revista de Direito Bancário, do Mercado de Capitais e da Arbitragem, vol. 2, ano 3, 2000.

VALÉRIO, Marco Aurélio Gumieri. “A arbitragem nas sociedades anônimas: vinculação dos acionistas novos, ausentes, dissidentes e administradores à cláusula compromissória estatutária. Inclusão do $\S 3^{\circ}$ ao art. 109 pela Lei 10.303/2001”. Revista de Direito Mercantil Industrial, Econômico e Financeiro, vol. 139, 2005.

"Divulgação dos processos de arbitragem nos balanços demonstrativos das empresas brasileiras de capital aberto". VIII Congresso Iberoamericano de Derecho Societario y de Empresa/XII Congresso Argentino de Derecho Societario, 2013.

VERÇOSA, Haroldo Malheiros Duclerc. Curso de Direito Comercial, $2^{\mathrm{a}}$ Ed., vol. 3. São Paulo: Malheiros, 2011.

VILELA, Marcelo Dias Gonçalves. Arbitragem no Direito Societário. Belo Horizonte: Mandamentos, 2004.

; SALUM, Rafaella Coscarelli. "Note: Parties not indicated, Court of Justice of the State of São Paulo, Case No. 2031444-61.2016.8.26.0000, 14 December 2016”. Revista Brasileira de Arbitragem, vol. XIV, issue 55, 2017.

WALD, Arnoldo. “A reforma da Lei das Sociedades Anônimas: os Direitos dos Minoritários na Nova Lei das S.A. In: LOBO, Jorge (coord.) A reforma da Lei das Sociedades Anônimas: Inovações e Questões Controvertidas da Lei 10.303, de 31 de outubro de 2001, $2^{\text {a }}$ Ed. Rio de Janeiro: Forense, 2002.

"A arbitragem e as sociedades de economia mista". Revista de

Direito Bancário e do Mercado de Capitais, vol. 19, 2003. 
. “A crise e a arbitragem no direito societário e bancário. Revista de

Arbitragem e Mediação, vol. 20, 2009.

; BORJA, Ana Gerdau e VIEIRA, Maíra de Melo. “A posição dos tribunais em matéria de arbitragem no último biênio (2011-2012)". Revista de Arbitragem e Mediação, vol. 9, $\mathrm{n}^{\circ}$ 35, 2012.

WEBER, Ana Carolina. "Note - Torque Fundo de Investimento Multimercado v. Companhia Brasileira de Distribuição, Comissão de Valores Mobiliários, Processo Administrativo CVM n RJ2012/13700, 18 June 2013”. Revista Brasileira de Arbitragem, vol. X, issue 39, 2013.

WELLISCH, Julya Sotto Mayor. Sistema de Regulação do Mercado de Valores Mobiliários: para além da informação. Dissertação (mestrado em Direito) - Programa de Pós-graduação em Direito Comercial da Faculdade de Direito da Universidade de São Paulo (orientador Professor Doutor José Alexandre Tavares Guerreiro). São Paulo, 2016.

\section{b. JURISPRUDÊNCIA}

STF, Agravo Regimental na Sentença Estrangeira $n^{\circ}$ 5.206-7, do Reino da Espanha, Rel. Ministro Sepúlveda Pertence, julgado em 12 de dezembro de 2001.

TJRJ, Agravo de Instrumento n 07839/2003, $13^{\text {a }}$ Câmara Cível, Des. Rel. Ademir Paulo Pimentel, julgado em 25 de junho de 2003.

TJSP, Apelação n ${ }^{\circ}$ 107.779-2, 14 ${ }^{\mathrm{a}}$ Câmara, Des. Rel. Domingos Franciulli Netto, julgado em 23 de setembro de 1986. Disponível em Revista dos Tribunais, vol. 615, 1987, pp. 66 e ss.

TJSP, Agravo de Instrumento $\mathrm{n}^{\circ}$ 2031444-61.2016.8.26.0000, 2ª Câmara Reservada de Direito Empresarial, Des. Rel. Caio Marcelo Mendes de Oliveira, julgado em 14 de dezembro de 2016.

CVM, Inquérito Administrativo n 22/99, Rel. Diretor Marcelo Trindade, julgado em 16 de agosto de 2001. 
CVM, Processo Administrativo Sancionador n ${ }^{\circ}$ RJ 2002/1822, Rel. Norma Jonssen Parente, julgado em 6 de maio de 2005.

CVM, Processo Administrativo Sancionador n RJ 2006/4776, Rel. Diretor Pedro Marcílio de Sousa, julgado em 17 de janeiro de 2007.

CVM, Processo Administrativo Sancionador $n^{\circ}$ RJ 2006/5928, Rel. Diretor Pedro Oliva Marcílio de Sousa, julgado em 17 de abril de 2007.

CVM, Processo Administrativo no RJ 2008/0713 (Reg. Col. no 6517/2009). Rel. Diretor Otávio Yazbek, julgado em 9 de fevereiro de 2010.

CVM, Processo Administrativo n RJ 2010/6865 (Reg. Col. nº 7189/2010), Rel. Diretor Eli Loria, julgado em 21 de setembro de 2010.

CVM, Processo Administrativo no RJ 2012/13700 (Reg. Col. n 8659/2013), Rel. Diretora Ana Dolores Moura Carneiro de Novaes, julgado em 18 de junho de 2013.

\section{c. NotícIAS}

Confidencialidade de arbitragem é relativizada (por Fernando Eduardo Serec e Eduardo Rabelo Kent Coes). Consultor Jurídico, publicação em 13 de setembro de 2010. Disponível em <http://www.conjur.com.br/2010-set-13/confidencialidade-arbitragem-relativizadamercado>, acesso em dezembro de 2018.

Especialista critica arbitragem em mercado de capitais (por Elton Bezerra). Consultor Jurídico, publicação em 30 de maio de 2013. Disponível em <http://www.conjur.com.br/2013-mai-30/arbitragem-retrocesso-mercado-capitaisprofessora-gv>, acesso em novembro de 2018.

Sigilo é obstáculo à formação jurisprudência arbitral (por Pedro Canário). Consultor Jurídico, publicação em 31 de maio de 2013. Disponível em <http://www.conjur.com.br/2013-mai-31/sigilo-obstaculo-formacao-jurisprudenciaarbitral-dizem-especialistas>, acesso em dezembro de 2018. 
Câmara de Arbitragem da Bovespa rebate críticas. Consultor Jurídico, publicação em 7 de junho de 2013. Disponível em <https://www.conjur.com.br/2013-jun-07/camaraarbitragem-bovespa-rebate-criticas-professora-gv>, acesso em novembro de 2018.

CAM-CCBC administra número recorde de procedimentos. Sítio eletrônico do CAMCCBC, publicado em 18 de dezembro de 2018. Disponível em <https://ccbc.org.br/camccbc-centro-arbitragem-mediacao/noticias-cam-ccbc/novidades-cam-ccbc/noticiascam/cam-ccbc-recorde-de-procedimentos/>, acesso em dezembro de 2018.

\section{d. Outros}

ADVISORY COMMITTEE ON CORPORATE DISCLOSURE. Report of the Advisory Committee on Corporate Disclosure to the Securities and Exchange Commission. Washington: U.S. Government Printing Office, 1977. Disponível em <https://hdl.handle.net/2027/pst.000012956579>, acesso em julho de 2018.

Arbitragem no Brasil - Pesquisa CBAr-IPSOS. Relatório elaborado por André de $\begin{array}{llll}\text { Albuquerque } & \text { Cavalcanti } & \text { Abbud. } & \text { Disponível }\end{array}$ <http://www.cbar.org.br/PDF/Pesquisa_CBAr-Ipsos-final.pdf $>$, acesso em novembro de 2018 .

2018 International Arbitration Survey: The Evolution of International Arbitration. White \& Case e School of International Arbitration, Queen Mary University of London, 2018. Disponível em <http://www.arbitration.qmul.ac.uk/media/arbitration/docs/2018International-Arbitration-Survey---The-Evolution-of-International-Arbitration-(2).PDF>, acesso em novembro de 2018.

Instituto Brasileiro de Governança Corporativa. Código das Melhores Práticas de Governança Corporativa. 5a Ed. São Paulo: IBGC, 2015. Disponível em $<$ http://www.ibgc.org.br/userfiles/files/Publicacoes/Publicacao-IBGCCodigoCodigodasMelhoresPraticasdeGC-5aEdicao.pdf>, acesso em outubro de 2018.

CVM. Recomendações da CVM sobre Governança Corporativa, 2002. Disponível em <http://www.cvm.gov.br/export/sites/cvm/decisoes/anexos/0001/3935.pdf>, acesso em outubro de 2018. 
OECD, G20/OECD Principles of Corporate Governance, OECD Publishing: Paris, 2015. Disponível em <http://dx.doi.org/10.1787/9789264236882-en>, acesso em julho de 2018. International Law Association. Report on Confidentiality in International Commercial Arbitration, 2010. 


\section{ANEXO I}

\section{Análise do item 4.5 dos Formulários de Referência das companhias listadas no Novo Mercado ${ }^{462}$}

\begin{tabular}{|c|c|c|}
\hline Razão social & $\begin{array}{l}\text { Data de } \\
\text { entrega }\end{array}$ & Redação item 4.5 FR \\
\hline $\begin{array}{l}\text { ALIANSCE SHOPPING } \\
\text { CENTERS S.A. }\end{array}$ & $02 / 01 / 2019$ & $\begin{array}{l}\text { Em } 31 \text { de dezembro de } 2017 \text {, a Companhia e suas controladas não possuíam processos sigilosos que tenham impacto relevante } \\
\text { para a Companhia. }\end{array}$ \\
\hline $\begin{array}{l}\text { CENTRO DE IMAGEM } \\
\text { DIAGNOSTICOS S.A. }\end{array}$ & $13 / 12 / 2018$ & Na data deste Formulário de Referência, a Companhia não é parte em processos sigilosos relevantes. \\
\hline $\begin{array}{l}\text { ALPER CONSULTORIA } \\
\text { E CORRETORA DE } \\
\text { SEGUROS S.A. }\end{array}$ & $21 / 12 / 2018$ & $\begin{array}{l}\text { Existem processos sigilosos relevantes em que a Companhia e/ou suas controladas sejam parte. Abaixo a análise e impacto do } \\
\text { caso em caso de perda e seus valores envolvidos: (1) Análise do impacto em caso de perda de processo: Em caso de perda, } \\
\text { Companhia pode ser condenada a indenizar a parte contrária nos termos do pedido contraposto, no valor atualizado d } \\
\mathrm{R} \$ 537.244,00 \text {. Valor provisionado: N/A. Chance de perda: Possível. (2) Análise do impacto em caso de perda de processo: En } \\
\text { caso de perda, a Companhia pode ser condenada a indenizar a parte contrária nos termos do pedido contraposto, ainda nã } \\
\text { formulado. Valor provisionado: N/A. Chance de perda: Possível. (3) Análise do impacto em caso de perda de processo: Em cas } \\
\text { de perda, a Companhia pode ser condenada a pagar o valor provisionado. Valor provisionado: } \mathrm{R} \$ 2.077 .210,00 \text {. Chance de perda } \\
\text { Provável. (4) Análise do impacto em caso de perda de processo: Em caso de perda, a Companhia poderá ser condenada a indeniza } \\
\text { o reclamante pelos pedidos iniciais, que perfazem o valor atualizado de } \mathrm{R} \$ 1.716 .706,28 \text {. Valor provisionado: N/A. Chance d } \\
\text { perda: Remota. (5) Análise do impacto em caso de perda de processo: Estima-se como provável a perda a condenação dos pedido } \\
\text { que perfazem o valor atualizado de } \mathrm{R} \$ 512.316,90 \text {. Valor provisionado: } \mathrm{R} \$ 512.316,90 \text {. Chance de perda: Provável. }\end{array}$ \\
\hline ANIMA HOLDING S.A. & $09 / 11 / 2018$ & Em 31 de dezembro de 2017, não éramos parte em processos sigilosos relevantes. \\
\hline $\begin{array}{l}\text { AREZZO INDÚSTRIA E } \\
\text { COMÉRCIO S.A. }\end{array}$ & $12 / 12 / 2018$ & $\begin{array}{l}\text { Não há processos sigilosos relevantes em que a Companhia ou suas controladas sejam parte e que não tenham sido divulgado } \\
\text { nos itens } 4.3 \text { e } 4.4 \text { acima. }\end{array}$ \\
\hline $\begin{array}{l}\text { B2W - COMPANHIA } \\
\text { DIGITAL }\end{array}$ & $28 / 12 / 2018$ & Na presente data, não há processos sigilosos relevantes em que o emissor ou suas controladas sejam parte. \\
\hline
\end{tabular}




$$
\begin{aligned}
& \text { B3 S.A. - BRASIL, } \\
& \text { BOLSA, BALCÃO }
\end{aligned}
$$

BB SEGURIDADE PARTICIPAÇÕES S.A

BIOSEV S.A.

BK BRASIL

OPERAÇÃO E

ASSESSORIA A

RESTAURANTES SA

BRASIL BROKERS

PARTICIPACOES S.A

07/01/2018

$30 / 08 / 2018$

$30 / 11 / 2018$

$27 / 11 / 2018$

$27 / 11 / 2018$

BR MALLS

PARTICIPACOES S.A

$07 / 11 / 2018$

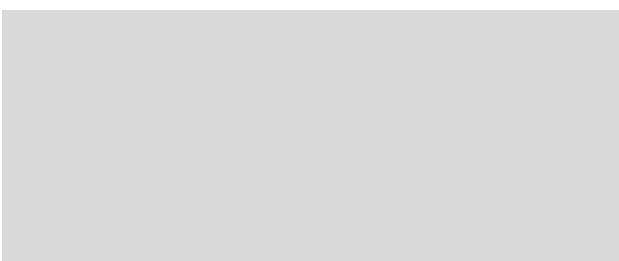

BRASIL PHARMA S.A.

$31 / 05 / 2018$
Arbitragem instaurada nos termos da cláusula II.3. do Acordo em Controle de Concentração divulgado ao mercado mediante a publicação de Fato Relevante em 22 de março de 2017. Impacto em caso de perda: Eventual decisão desfavorável poderia gerar impactos em perda potencial de receita relativa especialmente ao acesso à central depositária. Valores envolvidos: Não são passíveis de estimativa no momento.

A BB Seguridade e suas controladas não figuram como parte em processos sigilosos considerados relevantes, que não tenham sido divulgados nos itens anteriores.

Na data desde Formulário de Referência, não há processos sigilosos relevantes em que nós sejamos parte.

Em 31de dezembro de 2017, a Companhia e suas controladas não figuravam como partes em processos sigilosos relevantes que não tenham sido divulgados nos itens anteriores.

Em 31 de dezembro de 2017, não há processos sigilosos movidos contra a Companhia.

(1) A Companhia é autora de procedimento arbitral no valor de $\mathrm{R} \$ 50.000$ mil com objetivo de obter indenização em decorrência de vício oculto e não cumprimento de obrigação prevista em contrato de aquisição de uma das suas controladas. No referido processo, foi apresentada reconvenção em decorrência de discussão sobre o cumprimento de obrigação prevista no contrato de aquisição. Em caso de perda, o impacto para a Companhia será exclusivamente financeiro. (2) Havia, ainda, arbitragem ingressada pelo Espólio de Alberto e outros contra a Cima, sociedade controlada pela Companhia, e outros, em razão do descumprimento de obrigações contratuais que culminaram no envolvimento do autor e seus sucessores em ação de Execução de Título Extrajudicial e Reclamação Trabalhista. Em 16/08/2017 foi proferida decisão na arbitragem onde houve a condenação da outra parte envolvida para o pagamento de indenização dos valores despendidos. Comprovado o pagamento, foi proferida sentença em 13/12/2017 julgando extinta a execução. Não houve nenhuma perda ou impacto financeiro para Cima ou para a Companhia, até o momento.

(1) Processo $n^{\circ}$ 0011894-25.2012.4.01.3900 (Distribuição por dependência das Execuções Fiscais $n^{\circ}$ 2001.39.00.002396-4, 2001.39.00.002397-7, 2001.39.00.003509-8, 2001.39.00.003508-5. (2) Arbitragem Beauty'in Em fevereiro de 2017, a Beauty'in Comércio de Bebidas e Cosméticos S.A. ("Beauty'in") requereu a instauração de procedimento arbitral, de acordo com as normas da Câmara de Arbitragem do Mercado da BM\&FBovespa, contra a Farmais Produtos S.A., Brasil Pharma S.A. e Banco BTG Pactual S.A. O procedimento arbitral está relacionado às questões que decorrem do Contrato de Compra e Venda de Ações e Outras Avenças, celebrado entre a Farmais Produtos S.A. ("Farmais Produtos") e a Sra. Cristiana Arcangeli ("Cristiana"), que teve como objeto a alienação da participação detida pela Farmais Produtos na Beauty’in para Cristiana ("Operação"). Os termos da arbitragem estão submetidos a obrigações de confidencialidade. Em março de 2017, a Farmais Produtos e a Companhia exerceram seu direito de indicar um árbitro para compor o Tribunal Arbitral responsável pela condução do procedimento instaurado. O Banco BTG Pactual S.A., por sua vez, solicitou sua exclusão do procedimento arbitral em 22 de março de 2017 , por não ser parte da Operação. Em novembro do mesmo ano, foi composto o tribunal arbitral pelos Drs. Charles Isidoro Gruenberg, indicado pela requerente, José Emílio Nunes Pinto, indicado pelos requeridos, e Giovanni Ettore Nanni, indicado pelos coárbitros para presidir o tribunal arbitral. Na data de apresentação deste Formulário de Referência, já tinha sido apresentada a réplica da requerente, estando no período de prazo para apresentação da resposta pelos requeridos. Como não houve qualquer decisão no âmbito desta arbitragem, não há, portanto, quaisquer impactos em nossas demonstrações financeiras referentes ao 


\begin{tabular}{|c|c|c|}
\hline & & último exercício social. \\
\hline BR PROPERTIES S.A. & $12 / 12 / 2018$ & Em 31 de março de 2017, não havia processos sigilosos em que nós ou quaisquer de nossas controladas sejamos parte. \\
\hline BCO BRASIL S.A. & 07/01/2019 & O Banco e suas controladas não figuram como parte em processos sigilosos considerados relevantes. \\
\hline $\begin{array}{l}\text { BRASILAGRO - CIA } \\
\text { BRAS DE PROP } \\
\text { AGRICOLAS }\end{array}$ & $30 / 11 / 2018$ & $\begin{array}{l}\text { Na data deste Formulário de Referência, nós e nossos controladas não possuíamos processos sigilosos relevantes, além dos } \\
\text { descritos nos itens } 4.3 \text { e } 4.4 \text { deste Formulário de Referência. }\end{array}$ \\
\hline BRF S.A. & $17 / 12 / 2018$ & $\begin{array}{l}\text { Na data deste Formulário de Referência não há processos sigilosos relevantes em que a Companhia ou suas controladas sejam } \\
\text { parte. }\end{array}$ \\
\hline $\begin{array}{l}\text { CAMIL ALIMENTOS } \\
\text { S.A. }\end{array}$ & 03/08/2018 & Na data de entrega deste formulário de referência, a Companhia não era parte em processos sigilosos relevantes. \\
\hline ATACADÃO S.A. & $17 / 12 / 2018$ & $\begin{array}{l}\text { Além do que foi divulgado e discutido acima, na data deste Formulário de Referência não há nenhum processo relevante sob } \\
\text { sigilo no qual sejamos parte. }\end{array}$ \\
\hline CCR S.A. & $27 / 12 / 2018$ & $\begin{array}{l}\text { (1) PIC 37/2018, Juízo: Ministério Público do Estado de São Paulo, Tipo de Ação: Procedimento Investigatório Criminal, Data } \\
\text { de instauração: Maio/2018, Polo Ativo: Ministério Público do Estado de São Paulo, Objeto: Apurar os fatos contidos em } \\
\text { reportagem publicada no jornal "O Estado de São Paulo" do dia 24/02/2018, sob o título "CCR pagou a ex-diretor da Dersa, diz } \\
\text { Assad". Valores, bens ou direitos envolvidos: Não aplicável, Análise de impacto em caso de perda do processo: Não aplicável. } \\
\text { (2) Inquérito Criminal no 1.25.000.003687/2017-67, Juízo: Ministério Público Federal, Instância: Procuradoria da República no } \\
\text { Paraná, Tipo de Ação: Inquérito Criminal, Valores, bens ou direitos envolvidos: Não aplicável, Análise de impacto em caso de } \\
\text { perda do processo: Não aplicável }\end{array}$ \\
\hline $\begin{array}{l}\text { CCX CARVÃO DA } \\
\text { COLÔMBIA S.A. }\end{array}$ & $30 / 10 / 2018$ & $\begin{array}{l}\text { Na data deste Formulário de Referência, não há processos sigilosos relevantes em que a Companhia ou suas controladas sejam } \\
\text { parte. }\end{array}$ \\
\hline CIA HERING & 03/09/2018 & Não aplicável. O emissor não possui processos sigilosos. \\
\hline CIELO S.A. & $10 / 12 / 2018$ & A Companhia não possui processos sigilosos relevantes que não foram divulgados nos itens 4.3 e 4.4 . \\
\hline $\begin{array}{l}\text { CIA SANEAMENTO DE } \\
\text { MINAS GERAIS- } \\
\text { COPASA MG }\end{array}$ & $20 / 12 / 2018$ & $\begin{array}{l}\text { Não há processos sigilosos relevantes em que a Companhia ou sua controlada sejam parte. Os processos considerados relevantes } \\
\text { pela Companhia foram divulgados nos itens } 4.3,4.4,4.6 \text { e } 4.7 \text { deste Formulário de Referência. }\end{array}$ \\
\hline COSAN S.A. & $14 / 11 / 2018$ & $\begin{array}{l}\text { A Comgás, controlada da Companhia, é autora de ação judicial em que discute os prejuízos patrimoniais por ela sofridos em } \\
\text { razão das condições de aquisição do gás natural. Em decorrência do processo, a Comgás depositou o valor controverso original } \\
\text { de } \mathrm{R} \$ 294.976 .498,98 \text { nos autos do processo. Posteriormente, obteve liminar autorizando-a a garantir o valor controverso } \\
\text { mediante fiança bancária emitida por instituição de primeira linha. Por tal razão, além do valor depositado em juízo, o valor } \\
\text { controverso histórico de } \mathrm{R} \$ 641.341 .962,65 \text { está garantido por carta fiança. Em caso de improcedência das demandas, o direito } \\
\text { da outra parte ao recebimento integral dos preços será reconhecido e os valores depositados/garantidos em juízo poderão ser } \\
\text { levantados/executados, operando-se ainda a sucumbência. }\end{array}$ \\
\hline
\end{tabular}


COSAN LOGISTICA

S.A.

(1) A Rumo Malha Norte, Rumo Malha Sul, Rumo Malha Paulista e a Rumo S/A eram partes em um procedimento arbitral confidencial cujo valor total dos pedidos somava a quantia de $\mathrm{R} \$ 305,2$ milhões. Foi prolatada sentença arbitral e, após liquidação de sentença arbitral, no segundo trimestre de 2017, apurou-se ser devido pela Companhia R \$114milhões, que foram devidamente pagos. Apesar de pagos os valores, a parte adversa entendeu que houve pagamento a destempo e iniciou cumprimento de sentença para exigir multa pelo cumprimento a supostamente realizado destempo. Rumo apresentou impugnação ao cumprimento de sentença, a qual foi rejeitada, tendo sido interposto Agravo de Instrumento, o qual teve efeito suspensivo concedido. Aguarda-se o julgamento do Agravo de Instrumento Interposto por Rumo. (2) Além disso, a Rumo S.A. ("Rumo") é parte em procedimento arbitral confidencial a respeito de um acordo de acionistas de uma de suas subsidiárias relevantes. O valor envolvido neste procedimento pode representar um dispêndio significativo para a Companhia, estimado pela parte contrária em $\mathrm{R} \$ 544 \mathrm{milhões.}$ A determinação do valor efetivamente envolvido na arbitragem ("Montante Envolvido") depende de eventual produção probatória, ainda não iniciada, tendo em vista que se aguarda decisão do Tribunal Arbitral a respeito dos argumentos da Rumo referentes à desnecessidade de produção de novas provas face aos documentos já apresentados. Os possíveis desfechos do procedimento para a Rumo são: (i) a condenação da Rumo ao pagamento, em moeda corrente, de montante correspondente a até o Montante Envolvido; ou (ii) a emissão de novas ações da Rumo em quantidade correspondente a até o Montante Envolvido, o que poderá diluir a participação dos acionistas da Rumo em seu capital social. A Companhia estima o risco de pagamento em pecúnia como remoto e o pagamento em ações como possível. Em 31/12/2017 aguardava-se designação de audiência de instrução.

(3) Em adição, a Rumo Malha Norte, Rumo Malha Sul, Rumo Malha Paulista e a Rumo S/A são partes em procedimento arbitral confidencial, cujo valor total dos pedidos soma a quantia de R \$430 milhões. O procedimento foi instaurado pela parte contrária sob a alegação de que Rumo teria dado causa à rescisão de contrato de serviço transporte ferroviário e investimentos, diante do que requereu indenização. A Rumo apresentou reconvenção, na qual pretende seja reconhecida a improcedência dos pleitos da parte contrária, bem como a responsabilidade da parte contrária em arcar com as perdas e danos decorrentes de sua rescisão imotivada. As partes apresentaram requerimento e resposta/reconvenção. O painel arbitral já foi formado. Em 31/12/2017 aguardava-se apresentação das alegações iniciais. (4) Em 2010, a Prumo Engenharia Ltda. ("Prumo Engenharia"), empresa prestadora de serviço da então ALL - América Latina Logística SA (“ALL”), foi acusada de incorrer em práticas trabalhistas irregulares durante a execução de serviço de engenharia para uma subsidiária da ALL. Independentemente e sem prejuízo de sua defesa e da alegação de que não houve práticas trabalhistas irregulares, a Prumo Engenharia já reconheceu e assumiu responsabilidade integral pela condição dos trabalhadores em questão, inclusive perante a Superintendência Regional do Trabalho, isentando a ALL de toda e qualquer responsabilidade. Entretanto, a Rumo Malha Paulista S.A. ("Malha Paulista"), subsidiária da Rumo S.A., nova denominação da sociedade então subsidiária da ALL que contratou o serviço da Prumo Engenharia em 2010, foi incluída indevidamente, na visão da Companhia, no cadastro de empregadores do Ministério do Trabalho por referidas práticas de responsabilidade da Prumo Engenharia. Os fatos em questão estão em discussão no Poder Judiciário e no Ministério do Trabalho e Emprego. Em 13/04/2018 foi concedida medida liminar pela 83 $3^{\text {a }}$ Vara do Trabalho de São Paulo, em ação anulatória, determinando a exclusão da Malha Paulista do referido cadastro até o trânsito em julgado do processo judicial, o qual tramita em segredo de justiça. A Companhia repudia qualquer prática contrária aos direitos trabalhistas, reforça o cumprimento de suas rígidas políticas internas em relação ao respeito à legislação aplicável.

CPFL ENERGIA S.A. 24/08/2018 Todos os processos relevantes foram divulgados nos itens anteriores. 
CPFL ENERGIAS

RENOVÁVEIS S.A.

$28 / 12 / 2018$

Em 31 de dezembro de 2017, a Companhia era parte passiva e ativa em 06 procedimentos arbitrais, de natureza cível, no valor de causa total atualizado de $\mathrm{R} \$ 735.874 .924,59$. De acordo com a opinião de seus advogados externos, o prognóstico de perda foi classificado como possível em 05 procedimentos e como remota em 01 procedimento, razão pela qual não foi constituída provisão contábil.

\begin{tabular}{|c|c|c|}
\hline $\begin{array}{l}\text { CR2 } \\
\text { EMPREENDIMENTOS } \\
\text { IMOBILIARIOS S.A. }\end{array}$ & $18 / 12 / 2018$ & $\begin{array}{l}\text { Na presente data, não há processos sigilosos relevantes em que a Companhia ou suas controladas sejam parte e que não tenham } \\
\text { sido divulgados nos itens } 4.3 \text { e } 4.4 \text { acima. }\end{array}$ \\
\hline $\begin{array}{l}\text { CSU CARDSYSTEM } \\
\text { S.A. }\end{array}$ & $21 / 08 / 2018$ & $\begin{array}{l}\text { ão há processos sigilosos relevantes em que o emissor ou suas controladas sejam parte e que não tenham sido divulgados nos } \\
\text { ens } 4.3 \text { e } 4.4 \text { acima. }\end{array}$ \\
\hline $\begin{array}{l}\text { CVC BRASIL } \\
\text { OPERADORA E } \\
\text { AGÊNCIA DE } \\
\text { VIAGENS S.A. }\end{array}$ & 02/01/2019 & $\begin{array}{l}\text { Na data de apresentação do presente Formulário de Referência não há processos sigilosos relevantes em que a Companhia ou } \\
\text { suas controladas sejam parte e que não tenham sido divulgados nos itens } 4.3 \text { e } 4.4 \text { acima. }\end{array}$ \\
\hline $\begin{array}{l}\text { CYRELA } \\
\text { COMMERCIAL } \\
\text { PROPERT S.A. EMPR } \\
\text { PART }\end{array}$ & 17/12/2018 & $\begin{array}{l}\text { Na presente data, não há processos sigilosos relevantes em que a Companhia ou suas controladas sejam parte e que não tenham } \\
\text { sido divulgados nos itens acima. }\end{array}$ \\
\hline $\begin{array}{l}\text { CYRELA BRAZIL } \\
\text { REALTY S.A. } \\
\text { EMPREEND E PART }\end{array}$ & $30 / 07 / 2010$ & $\begin{array}{l}\text { a presente data, não há processos sigilosos relevantes em que a Companhia ou suas controladas sejam parte e que não tenham } \\
\text { do divulgados nos itens acima. }\end{array}$ \\
\hline $\begin{array}{l}\text { DIRECIONAL } \\
\text { ENGENHARIA S.A. }\end{array}$ & $31 / 05 / 2018$ & ão há processos sigilosos relevantes em que a Companhia ou suas controladas sejam parte. \\
\hline DURATEX S.A. & 26/12/2018 & $\begin{array}{l}\text { A Companhia não foi comunicada até o presente momento sobre a existência de processos sigilosos que gerem impacto no caso } \\
\text { de perda. }\end{array}$ \\
\hline $\begin{array}{l}\text { ECORODOVIAS } \\
\text { INFRAESTRUTURA E } \\
\text { LOGÍSTICA S.A. }\end{array}$ & 21/12/2018 & $\begin{array}{l}\text { Não existem outros processos sigilosos relevantes em que a Companhia ou suas Controladas sejam parte e que não tenham sido } \\
\text { divulgados nos itens } 4.3 \text { e } 4.4 \text { acima. }\end{array}$ \\
\hline $\begin{array}{l}\text { ELETROPAULO } \\
\text { METROP. ELET. SAO } \\
\text { PAULO S.A. }\end{array}$ & $21 / 12 / 2018$ & $\begin{array}{l}\text { Na data deste Formulário de Referência, a Companhia não figurava como parte em processos sigilosos relevantes que não tenham } \\
\text { sido divulgados nos itens anteriores. }\end{array}$ \\
\hline EMBRAER S.A. & 13/11/2018 & Não há processos judiciais, administrativos ou arbitrais sigilosos relevantes em que a Companhia ou suas controladas sejam parte. \\
\hline $\begin{array}{l}\text { EDP - ENERGIAS DO } \\
\text { BRASIL S.A. }\end{array}$ & 01/11/2018 & $\begin{array}{l}\text { não possuem processos sigilosos relevantes em que a Companhia e/ou suas controladas sejam } \\
\text { lgados acima. }\end{array}$ \\
\hline
\end{tabular}


Em 31 de dezembro de 2017, salvo pelo processo abaixo disposto, a Companhia e suas controladas não eram partes em nenhum processo sigiloso relevante: Ação Anulatória relativa a Procedimento Arbitral. a. Análise do Possível Impacto para a Companhia e suas Controladas: Trata-se de processo que tramita na $2^{\mathrm{a}}$ Vara de Falências e Recuperações Judiciais de São Paulo, e que consiste em ação anulatória de sentença arbitral que julgou procedentes pedidos formulados pela subsidiária da Companhia, qual seja Eneva Comercializadora de Energia Ltda. ("Eneva Comercializadora") no procedimento arbitral no 22/2014, instaurado contra terceiro (o qual já se encontra encerrado). Em 16 de maio de 2017, foi proferida decisão que julgou parcialmente procedente o pedido de reconsideração da Eneva Comercializadora, de forma que foram suspensos os efeitos financeiros imediatos da decisão (determinando a devolução de $\mathrm{R} \$ 38.337 .448,84$ ). Em 29 de junho de 2017, uma das partes do processo requereu o julgamento antecipado da lide, tendo sido proferida sentença em 10 de julho de 2017, na qual foram julgados improcedentes os pedidos constantes da petição inicial. Contra a sentença, foi interposto pela parte contrária à Eneva Comercializadora o recurso de apelação. Eventual decisão desfavorável nesse processo, no qual a subsidiária Eneva Comercializadora e outra parte (fora do grupo da Companhia) figuram na qualidade de rés, resultará (i) na perda pela Companhia do valor mencionado no item (b) abaixo (o qual já foi desembolsado pela Companhia em virtude de liminar) (ii) no eventual pagamento de penalidades que podem vir a ser impostas pelo agente setorial e (iii) em eventual dano à imagem da referida subsidiária e, por conseguinte da Companhia no mercado de energia, o que poderá afetar adversamente a condição financeira e patrimonial da Companhia. $b$. Valores Envolvidos: O processo envolve o valor de $\mathrm{R} \$[38.337 .448,84]$, o qual, acrescido de eventuais penalidades a serem aplicadas pelo agente setorial em virtude de falta de lastro de energia, pode vir a ser desembolsado pela Companhia, no caso de provimento do recurso de apelação e consequente reforma da sentença.

\begin{tabular}{|c|c|c|}
\hline $\begin{array}{l}\text { ENGIE BRASIL } \\
\text { ENERGIA S.A. }\end{array}$ & $21 / 12 / 2018$ & Não há processos sigilosos relevantes e que não tenham sido divulgados nos itens 4.3 e 4.4 . \\
\hline $\begin{array}{l}\text { EQUATORIAL } \\
\text { ENERGIA S.A. }\end{array}$ & $31 / 10 / 2018$ & Em 31 de dezembro de 2017, a Companhia e suas controladas não eram parte em nenhum processo sigiloso relevante. \\
\hline $\begin{array}{l}\text { ESTACIO } \\
\text { PARTICIPACOES S.A. }\end{array}$ & $21 / 12 / 2018$ & Em 31 de dezembro de 2017, não éramos parte em processos sigilosos relevantes. \\
\hline ETERNIT S.A. & $22 / 11 / 2018$ & $\begin{array}{l}\text { Não há na Companhia e controladas processos que estão sob sigilo. Todos os processos considerados como relevantes já foram } \\
\text { enumerados nos itens } 4.3 \text { e } 4.4 \text {. }\end{array}$ \\
\hline $\begin{array}{l}\text { EVEN CONSTRUTORA } \\
\text { E INCORPORADORA } \\
\text { S.A. }\end{array}$ & $19 / 12 / 2018$ & Não se aplica. \\
\hline $\begin{array}{l}\text { EZ TEC EMPREEND. E } \\
\text { PARTICIPACOES S.A. }\end{array}$ & $18 / 12 / 2018$ & $\begin{array}{l}\text { Não aplicável, dado que não existem processos sigilosos relevantes em que a Companhia ou suas controladas sejam parte e que } \\
\text { não tenham sido divulgados nos itens } 4.3 \text { e } 4.4 \text {. }\end{array}$ \\
\hline $\begin{array}{l}\text { FERTILIZANTES } \\
\text { HERINGER S.A. }\end{array}$ & 09/11/2018 & Não existem processos sigilosos. \\
\hline FIBRIA CELULOSE S.A. & $07 / 11 / 2018$ & $\begin{array}{l}\text { A Companhia, como sucessora legal da Aracruz Celulose S.A., é parte em um acordo de acionistas com a Stora Enso OYJ ("Stora } \\
\text { Enso"), regulamentando o relacionamento das acionistas no que se refere à Veracel Celulose S.A. ("Veracel"). Em maio de 2014, } \\
\text { a Fibria iniciou um procedimento arbitral contra a Stora Enso, em decorrência de descumprimento de determinadas obrigações } \\
\text { previstas no acordo de acionistas da Veracel. Os valores envolvidos no procedimento arbitral são sigilosos. Com exceção do } \\
\text { procedimento arbitral acima mencionado, não existem processos sigilosos relevantes em que a Companhia ou suas controladas }\end{array}$ \\
\hline
\end{tabular}


sejam parte e que não tenham sido divulgados neste Formulário de Referência.

\begin{tabular}{|c|c|c|}
\hline FLEURY S.A. & 07/01/2019 & Companhia não possui processos sigilosos que possam abalar sua reputação ou capacidade financeira. \\
\hline GAFISA S.A. & $10 / 01 / 2019$ & $\begin{array}{l}\text { Em 31/12/17, a companhia possuía os seguintes processos sigilosos relevantes, todos procedimentos arbitrais: (1) processo n. } \\
302 / 2013 \text { - FIESP/SP, inadimplemento de contrato de construção, impacto: pagamento dos valores pleiteados R } \$ 2.915 .000,00 \text {; } \\
\text { (2) processo n. } 65 / 2013 \text { (658067) - CCBC, inadimplemento de contrato de construção, impacto: pagamento dos valores } \\
\text { pleiteados; (3) processo n. 91/2015 - AMCHAM, inadimplemento contratual, impacto: pagamento dos valores pleiteados: } \\
\text { R } \$ 15.000 .000,00 \text {. }\end{array}$ \\
\hline $\begin{array}{l}\text { GENERAL SHOPPING E } \\
\text { OUTLETS DO BRASIL } \\
\text { S.A. }\end{array}$ & $30 / 05 / 2018$ & $\begin{array}{l}\text { A Companhia e suas controladas não tem conhecimento de processos sigilosos relevantes em que a Companhia ou suas } \\
\text { controladas sejam parte e que não tenham sido divulgados nos itens } 4.3 \text { e } 4.4 \text { acima. }\end{array}$ \\
\hline GRENDENE S.A. & $10 / 12 / 2018$ & Não há processos sigilosos relevantes em que a Companhia ou suas controladas sejam parte. \\
\hline $\begin{array}{l}\text { HAPVIDA } \\
\text { PARTICIPACOES E } \\
\text { INVESTIMENTOS SA }\end{array}$ & $06 / 06$ & $\begin{array}{l}\text { Processo } \mathrm{n}^{\circ} \text {. } 51 \text { - Ação Civil Pública } \mathrm{n}^{\circ} \text {. 0565582-47.2015.8.05.0001 a. Impacto em caso de perda do processo Financeiro, } \\
\text { Operacional e Reputacional. Possível pagamento de indenização por danos morais coletivos, no valor imputado à causa (R\$ } \\
10.000 .000,00) \text {. Possível impacto operacional e reputacional em razão do risco de suspensão das atividades do Hospital Teresa } \\
\text { de Lisieux até a regularização de não conformidades que vão desde ocorrências de menor porte até aspectos regulatórios, } \\
\text { estruturais e operacionais. b. Valores, bens ou direitos envolvidos Trata-se de demanda judicial ajuizada pelo Ministério Público } \\
\text { do Estado da Bahia, por meio da qual se apontou a suposta existência de inconformidades sanitárias no Hospital Teresa de } \\
\text { Lisieux. Neste, o Ministério Público requer: (i) o saneamento das irregularidades apontadas pela DIVISA (Diretoria de Vigilância } \\
\text { Sanitária da Secretaria de Meio Ambiente); (ii) a apresentação de licença sanitária para todos os setores do Hospital, a qual já foi } \\
\text { requerida ao órgão competente; (iii) a suspensão das atividades do Hospital, com substituição por outro equipamento hospitalar, } \\
\text { até o saneamento das irregularidades; (iv) a aplicação de multa diária de R } \$ 100.000,00 \text { em caso de descumprimento da liminar, } \\
\text { já tendo sido apresentados, dentro do prazo determinado de } 30 \text { dias, diversos documentos comprobatórios demonstrando o } \\
\text { cumprimento da decisão; e (v) a condenação ao pagamento de indenização aos pacientes impactados pelas supostas } \\
\text { irregularidades, atribuindo à causa o valor de } \mathrm{R} \$ 10.000 .000,00\end{array}$ \\
\hline $\begin{array}{l}\text { HELBOR } \\
\text { EMPREENDIMENTOS } \\
\text { S.A. }\end{array}$ & $30 / 05 / 2018$ & $\begin{array}{l}\text { ão há nenhum processo sigiloso relevante do qual a Companhia ou suas controladas sejam parte que não tenham sido divulgados } \\
\text { os itens } 4.3 \text { e } 4.4 \text {. }\end{array}$ \\
\hline HYPERA S.A. & $01 / 11 / 2018$ & 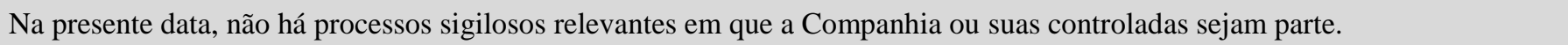 \\
\hline $\begin{array}{l}\text { IGUATEMI EMPRESA } \\
\text { DE SHOPPING } \\
\text { CENTERS S.A }\end{array}$ & 08/01/2019 & $\begin{array}{l}\text { Desconhecemos a existência de processos sigilosos relevantes em que nós ou nossas controladas sejam parte e que não tenham } \\
\text { sido divulgados acima. }\end{array}$ \\
\hline $\begin{array}{l}\text { INSTITUTO HERMES } \\
\text { PARDINI S.A. }\end{array}$ & 08/01/2019 & $\begin{array}{l}\text { ão aplicável, considerando que na data de apresentação deste Formulário de Referência, não havia processos sigilosos relevantes } \\
\text { os quais a Companhia ou controladas fossem parte. }\end{array}$ \\
\hline
\end{tabular}


INTERNATIONAL MEAL COMPANY ALIMENTACAO S.A.

INDUSTRIAS ROMI

S.A.

NOTRE DAME

INTERMEDICA

PARTICIPACOES SA

IOCHPE MAXION S.A.

Na data deste Formulário de Referência, não há processos sigilosos em que a Companhia e/ou suas controladas sejam partes e, portanto, não temos valores provisionados para tais demandas.

09/11/2018 A Companhia e suas controladas não são parte em processos sigilosos relevantes.

$08 / 01 / 2019$

Na data deste Formulário de Referência, a Companhia e suas controladas não figuravam como partes em processos sigilosos relevantes que não tenham sido divulgados nos itens anteriores.

Não há processos sigilosos relevantes em que a Companhia, suas controladas ou suas controladas em conjunto sejam parte e que não tenham sido divulgados nos itens 4.3 e 4.4 do Formulário de Referência.

IRB - BRASIL

RESSEGUROS S.A.

Até a data deste Formulário de Referência, não há processos sigilosos relevantes em que a Companhia seja parte.

Processos sigilosos relevantes: (1) Procedimento arbitral n. 93/17: Juízo: Câmara de Arbitragem do Mercado. Data de instauração:16 de agosto de 2017. Partes no processo: José Aurélio Valporto de Sá Junior e Associação dos Investidores Minoritários -AIDMIN (Requerentes); Banco Original S.A.; Banco Original do Agronegócio S.A.; J\&F Investimentos S.A.; ZMF Participações Ltda.; WWMB Participações Ltda.; JJMB Participações Ltda.; J\&F Participações; Pinheiros Fundo de Investimento em Participações; Joesley Mendonça Batista; Wesley Mendonça Batista; e JBS S.A. (Requeridos). Valor envolvido: R\$ 1.000.000,00 (valor da causa). Principais fatos: Procedimento arbitral para apuração de responsabilidade por danos sofridos pela JBS S.A. Prática do emissor ou de sua controlada que causou tal contingência: Não há prática da JBS S.A. e/ou de algumas de suas controladas em discussão. (2) Procedimento arbitral n. 94/17. Juízo: Câmara de Arbitragem do Mercado. Data de instauração: 11 de setembro de 2017. Partes no processo: J\&F Investimentos S.A.; Banco Original S.A.; e Banco Original Agronegócio S.A. (Requerentes); BNDES Participações S.A. e Caixa Econômica Federal (Requeridos); e JBS S.A. (Interveniente Anuente). Valor envolvido: R\$ 10.000.000,00 (valor da causa). Principais fatos: Procedimento arbitral referente ao direito de voto dos Requerentes e do BNDESPar no âmbito da assembleia geral extraordinária da JBS S.A. prevista para o dia $1^{\circ}$ de setembro de 2017, cuja realização foi suspensa por ordem judicial. Prática do emissor ou de sua controlada que causou tal contingência: Não há prática da JBS S.A. e/ou de algumas de suas controladas em discussão. (3) Pedido de Tutela de Urgência n. 108544397.2017.8.26.0100. Juízo: $2^{\text {a }}$ Vara de Falências e Recuperações Judiciais de São Paulo/SP. Instancia: $1^{\mathrm{a}}$ instância do Tribunal de Justiça do Estado de São Paulo. Data de instauração: 28 de agosto de 2017. Partes no processo: José Aurélio Valporto de Sá Júnior (Autor); JBS S.A.; Tarek Mohamed Farat; José Batista Sobrinho; J\&F Investimentos S.A.; Banco Original S.A.; e Banco Original do Agronegócio S.A. (Réus). Valor envolvido: R\$ 10.000,00 (valor da causa). Principais fatos: Pedido de tutela de urgência ajuizado para declarar impedimento de voto e reconhecimento de conflito de interesses dos Requeridos no tocante à assembleia geral extraordinária da JBS S.A. prevista para o dia $1^{\circ}$ de setembro de 2017 , cuja realização foi suspensa por ordem judicial. Em 12 de abril de 2018, o Autor desistiu do recurso de apelação por ele interposto contra a sentença que julgou a ação improcedente e a desistência foi homologada pelo Judiciário em 13 de abril de 2018. Prática do emissor ou de sua controlada que causou tal contingência: Não há prática da JBS S.A. e/ou de algumas de suas controladas em discussão. (4) Tutela cautelar antecedente n. 5013681-67.2017.4.03.6100. Juízo: $8^{\mathrm{a}}$ Vara Cível Federal de São Paulo/SP. Instância: $1^{\mathrm{a}}$ instância do Tribunal Regional Federal da $3^{\mathrm{a}}$ Região. Data de instauração: 30 de agosto de 2017. Partes no processo: BNDES Participações S.A. e Caixa Econômica Federal (Autores); JBS S.A.; J\&F Investimentos S.A.; Banco Original 


\begin{tabular}{|c|c|c|}
\hline & & $\begin{array}{l}\text { S.A.; Banco Original Agronegócio S.A. (Requeridos). Valor envolvido: R } \$ 10.000,00 \text { (valor da causa). Principais fatos: Pedido } \\
\text { de tutela de urgência ajuizado para declarar impedimento de voto de conflito de interesses dos Requeridos no tocante à assembleia } \\
\text { geral extraordinária da JBS S.A., prevista para o dia } 1^{\text {a }} \text { de setembro de } 2017 \text {, cuja realização foi suspensa por ordem judicial } \\
\text { proferida no âmbito de agravo de instrumento interposto nesse processo. Em } 26 \text { de março de } 2018 \text {, foi proferida sentença } \\
\text { extinguindo o processo em razão da falta de interesse de agir. Prática do emissor ou de sua controlada que causou tal } \\
\text { contingência: Não há prática da JBS S.A. e/ou de algumas de suas controladas em discussão. (5) Agravo de instrumento n. } \\
\text { 5016111-56.2017.4.03.0000. Juízo: } 1^{\mathrm{a}} \text { seção do Tribunal Regional Federal da } 3^{\mathrm{a}} \text { Região. Instância: } 2^{\mathrm{a}} \text { instância do Tribunal } \\
\text { Regional Federal da } 3^{\mathrm{a}} \text { Região. Data de instauração: } 1^{\circ} \text { de setembro de } 2017 \text {. Partes no processo: J\&F Investimentos S.A. } \\
\text { (Agravante); BNDES Participações S.A.; Caixa Econômica Federal (Agravadas). Valor envolvido: R } \$ 10.000,00 \text { (valor da } \\
\text { causa). Principais fatos: Agravo de instrumento interposto contra decisão interlocutória que reconheceu impedimento de voto da } \\
\text { Agravante no âmbito da assembleia geral extraordinária da JBS S.A., prevista para o dia } 1^{\mathrm{a}} \text { de setembro de } 2017 \text {, cuja realização } \\
\text { foi suspensa por ordem judicial. Prática do emissor ou de sua controlada que causou tal contingência: Não há prática da JBS } \\
\text { S.A. e/ou de algumas de suas controladas em discussão. }\end{array}$ \\
\hline $\begin{array}{l}\text { JHSF PARTICIPACOES } \\
\text { S.A. }\end{array}$ & 09/01/2019 & Na data-base de 31/12/2017não tínhamos conhecimento de processos com critérios descritos acima. \\
\hline JSL S.A. & $/ 2019$ & Na data deste Formulário, não há processos relevantes que tramitam em segredo de justiça. \\
\hline $\begin{array}{l}\text { KROTON } \\
\text { EDUCACIONAL S.A. }\end{array}$ & $20 / 12 / 2018$ & $\begin{array}{l}\text { Não há processos sigilosos relevantes em que nós e/ou nossas controladas sejamos parte e que não tenham sido divulgados na } \\
\text { seção } 4.3 \text { deste Formulário de Referência. }\end{array}$ \\
\hline $\begin{array}{l}\text { RESTOQUE } \\
\text { COMÉRCIO E } \\
\text { CONFECÇÕES DE } \\
\text { ROUPAS S.A. }\end{array}$ & $12 / 11 / 2018$ & Não há processos judiciais, administrativos ou arbitrais sigilosos, em que a Companhia ou a Dudalina sejam parte. \\
\hline LIGHT S.A. & 02/01/2019 & $\begin{array}{l}\text { Em } 31 \text { de dezembro de 2017, a Companhia não era parte em nenhum processo sigiloso relevante e que não tenham sido divulgados } \\
\text { nos itens } 4.3 \text { e } 4.4 \text { acima. }\end{array}$ \\
\hline LINX S.A. & $19 / 12 / 2018$ & Até a data deste Formulário de Referência, não há processos sigilosos relevantes em que nós sejamos parte. \\
\hline $\begin{array}{l}\text { LIQ PARTICIPAÇÕES } \\
\text { S.A. }\end{array}$ & 04/01/2019 & $\begin{array}{l}\text { Em } 02 \text { de fevereiro de 2017, a Companhia divulgou fato relevante informando o recebimento de correspondência da Câmara de } \\
\text { Arbitragem do Mercado notificando a requisição de procedimento arbitral em face da Companhia, pelas acionistas Verde AM } \\
\text { Dividendos Master Fundo de Investimentos em Ações, Verde AM Unique Long Bias Master FI Em Ações, Verde AM Sul } \\
\text { Energia FI Ações -Dividendos, Verde Master Fundo de Investimento Multimercado, Verde Equity Master Fundo de Investimento } \\
\text { Multimercado, Verde Strategy II Master Fundo de Investimento Em Ações, Verde AM Valor Dividendos Fundo De Investimento } \\
\text { Em Ações, Verde AM Performance Fundo de Investimentos Em Ações, Geen II Fund LLC, e Green Fund LLC ("Requerentes"). } \\
\text { Por meio do referido procedimento arbitral, as Requerentes reclamam o recebimento dos créditos referentes aos dividendos } \\
\text { mínimos obrigatórios declarados na Assembleia Geral Ordinária da Companhia de } 30 \text { de abril de } 2015 \text {, cujo pagamento está } \\
\text { suspenso por deliberação da Assembleia Geral Extraordinária da Companhia de } 29 \text { de dezembro de } 2015 \text { e da Assembleia Geral } \\
\text { Extraordinária } 19 \text { de dezembro de } 2016 \text {. O valor total dos dividendos declarados em Assembleia Geral Ordinária, realizada em } \\
30 \text { de abril de } 2015 \text {, foi de R } \$ 24.161 .539,91 \text {, dos quais as Requerentes teriam direito a uma parte deste valor, de acordo sua } \\
\text { participação no capital social à época. }\end{array}$ \\
\hline LOCALIZA RENT A & $14 / 12 / 2018$ & A Companhia e suas subsidiárias não têm conhecimento de processos sigilosos relevantes em que a Companhia ou suas \\
\hline
\end{tabular}




\begin{tabular}{|c|c|c|}
\hline CAR S.A. & & ntroladas sejam parte e que não tenham sido divulgados nos itens anteriores. \\
\hline $\begin{array}{l}\text { CIA LOCAÇÃO DAS } \\
\text { AMÉRICAS }\end{array}$ & 07/01/2019 & Não há processo sigiloso do qual a Companhia ou suas controladas sejam parte. \\
\hline $\begin{array}{l}\text { LOG COMMERCIAL } \\
\text { PROPERTIES }\end{array}$ & $02 / 01 / 2019$ & Companhia, suas controladas ou controladas em conjunto não estão sujeitas a qualquer processo sigiloso relevante. \\
\hline $\begin{array}{l}\text { LOG-IN LOGISTICA } \\
\text { INTERMODAL S.A. }\end{array}$ & $19 / 12 / 2018$ & Não há processos sigilosos relevantes. \\
\hline MARISA LOJAS S.A. & $27 / 11 / 2018$ & $\begin{array}{l}\text { A Companhia e suas controladas não possuem processos sigilosos relevantes em que a Companhia e suas controladas sejam parte } \\
\text { e que não tenham sido divulgados no item 4.3. }\end{array}$ \\
\hline LOJAS RENNER S.A. & $29 / 11 / 2018$ & Não há processos sigilosos relevantes. \\
\hline $\begin{array}{l}\text { LPS BRASIL - } \\
\text { CONSULTORIA DE } \\
\text { IMOVEIS S.A. }\end{array}$ & $06 / 12 / 2018$ & Em 31 de março de 2018não havia processos sigilosos relevantes nos quais a Companhia e suas controladas fossem partes. \\
\hline LUPATECH S.A. & 29/11/2018 & $\begin{array}{l}\text { (1) Ação Ordinária - Lupatech - Equipamentos e Serviços para Petróleo Ltda. (em segredo de justiça) a. valores, bens ou direitos } \\
\text { envolvidos: Ação que versa sobre a não utilização de certos meios gráficos por alegação de estarem protegidos por direitos } \\
\text { autorais dos autores da ação. Existe pleito indenizatório. Valor da causa aproximado, atualizado até } 31 \text { de dezembro de } 2017 \text {, é } \\
\text { de } \mathrm{R} \$ 624 \text { mil como perda provável, } \mathrm{R} \$ 2.080 \text { mil como perda possível e remota de } \mathrm{R} \$ 42.373 \text {. b. análise do impacto em caso de } \\
\text { perda do processo: Apenas impacto financeiro. c. valor provisionado, se houver provisão: } \mathrm{R} \$ 624.000,00 \text {. (2) Procedimento } \\
\text { Arbitral - Lupatech S.A. - Em Recuperação Judicial (confidencial) a. valores, bens ou direitos envolvidos: Ação versa quanto a } \\
\text { reparação de danos por contingências ocultadas da Companhia em alienação de participação societária, onde a Companhia figurou } \\
\text { com adquirente. Existe pleito indenizatório. Valor da causa aproximado, atualizado até } 31 \text { de dezembro de } 2017 \text {. O valor } \\
\text { perseguido pela Companhia é de } \mathrm{R} \$ 50 \text { milhões. } \text { b. análise do impacto em caso de perda do processo: Apenas impacto financeiro. } \\
\text { c. valor provisionado, se houver provisão: Não há }\end{array}$ \\
\hline $\begin{array}{l}\text { M.DIAS BRANCO S.A. } \\
\text { IND COM DE } \\
\text { ALIMENTOS }\end{array}$ & $24 / 10 / 2018$ & $\begin{array}{l}\text { Em } 31 \text { de dezembro de 2017, a Companhia não era parte em nenhum processo sigiloso. Todos os processos relevantes foram } \\
\text { descritos nas seções } 4.3 \text { acima. }\end{array}$ \\
\hline MAGAZINE LUIZA S.A. & $22 / 10 / 2018$ & $\begin{array}{l}\text { Na data deste Formulário de Referência, a Companhia e suas controladas não figuravam como partes em processos sigilosos } \\
\text { relevantes que não tenham sido divulgados nos itens anteriores. }\end{array}$ \\
\hline $\begin{array}{l}\text { MARFRIG GLOBAL } \\
\text { FOODS S.A. }\end{array}$ & $12 / 11 / 2018$ & $\begin{array}{l}\text { Na data deste Formulário de Referência, a Companhia não tem conhecimento de nenhuma demanda em processos sigilosos } \\
\text { relevantes em que a Companhia ou suas controladas sejam parte que não tenha sido divulgada nos itens anteriores e que possa } \\
\text { impactar nos negócios da Companhia e/ou suas controladas se eventualmente houver condenação. }\end{array}$ \\
\hline $\begin{array}{l}\text { MAHLE-METAL LEVE } \\
\text { S.A. }\end{array}$ & 03/01/2019 & Na data deste Formulário, não há processos sigilosos relevantes de que a Companhia ou suas controladas seja parte. \\
\hline $\begin{array}{l}\text { METALFRIO } \\
\text { SOLUTIONS S.A. }\end{array}$ & $24 / 10 / 2018$ & $\begin{array}{l}\text { A Companhia e suas sociedades controladas não são partes em processos sigilosos, que possam trazer impactos relevantes futuros } \\
\text { à Companhia. }\end{array}$ \\
\hline $\begin{array}{l}\text { MILLS ESTRUTURAS E } \\
\text { SERVIÇOS DE } \\
\text { ENGENHARIA S.A. }\end{array}$ & $02 / 01 / 2019$ & $\begin{array}{l}\text { Não aplicável, dado que a Companhia ou suas controladas não são partes em processos repetitivos ou conexos, baseados em fatos } \\
\text { e causas jurídicas semelhantes, que não estejam sob sigilo e que em conjunto sejam relevantes. }\end{array}$ \\
\hline
\end{tabular}




\begin{tabular}{|c|c|c|}
\hline MINERVA S.A. & 02/01/2019 & $\begin{array}{l}\text { Até } 31 \text { de dezembro de } 2017 \text {, a Companhia e suas controladas não eram parte em processos sigilosos relevantes, que não tenham } \\
\text { sido divulgados nos itens } 4.3 \text { e } 4.4 \text { deste Formulário de Referência. }\end{array}$ \\
\hline $\begin{array}{l}\text { MMX MINERACAO E } \\
\text { METALICOS S.A. }\end{array}$ & $26 / 12 / 2018$ & $\begin{array}{l}\text { Na data deste Formulário de Referência, a Companhia ou as suas controladas não são partes em quaisquer processos judiciais, } \\
\text { administrativos ou arbitrais cujas partes contrárias sejam administradores ou ex-administradores, controladores ou ex- } \\
\text { controladores ou investidores da Companhia ou de suas controladas. }\end{array}$ \\
\hline $\begin{array}{l}\text { MOVIDA } \\
\text { PARTICIPACOES SA }\end{array}$ & $18 / 12 / 2018$ & $\begin{array}{l}\text { Na data deste Formulário, não há processos relevantes que tramitam em segredo de justiça em que a Companhia ou suas } \\
\text { Controladas sejam parte. }\end{array}$ \\
\hline $\begin{array}{l}\text { MRV ENGENHARIA E } \\
\text { PARTICIPACOES S.A. }\end{array}$ & 20/12/2018 & $\begin{array}{l}\text { A Companhia e suas controladas não possuem processos sigilosos relevantes em que a Companhia ou suas controladas sejam } \\
\text { parte e que não tenham sido divulgados acima. }\end{array}$ \\
\hline MULTIPLUS S.A. & $13 / 11 / 2018$ & $\begin{array}{l}\text { Não há processos sigilosos relevantes que causem impacto em caso de perda, por não apresentar riscos financeiros para a } \\
\text { Companhia. Os processos citados no item 4.3. do Formulário não trazem riscos jurídicos de qualquer natureza para a Companhia, } \\
\text { além do risco financeiro lá mencionado. }\end{array}$ \\
\hline $\begin{array}{l}\text { NATURA } \\
\text { COSMETICOS S.A. }\end{array}$ & $13 / 12 / 2018$ & $\begin{array}{l}\text { A Natura possui um total atualizado de } \mathrm{R} \$ 24 \text { milhões em processos de Biodiversidade, classificados como chance de perda } \\
\text { remota, segundo nossa avaliação e de nossos assessores legais. Esses processos administrativos correspondem a defesa de } 70 \\
\text { (setenta) autos de infração lavrados, em } 2010 \text { e } 2011 \text {, pelo Instituto Brasileiro do Meio Ambiente e dos Recursos Naturais } \\
\text { Renováveis (IBAMA) por acusação de acesso supostamente irregular à biodiversidade brasileira para a realização de pesquisas } \\
\text { e desenvolvimento de produtos ou por suposta falta de repartição de benefícios decorrente dos acessos. Desse total, } 4 \text { (quatro) } \\
\text { autos de infração já foram anulados pelo IBAMA, mas ainda não há decisão administrativa com trânsito em julgado. Os demais, } \\
\text { aguardam julgamento. }\end{array}$ \\
\hline ODONTOPREV S.A. & $5 / 12 / 2018$ & Não há. \\
\hline $\begin{array}{l}\text { ÓLEO E GÁS } \\
\text { PARTICIPAÇÕES S.A. }\end{array}$ & 10/01/2019 & $\begin{array}{l}\text { Não aplicável, uma vez que até a presente data, a Companhia ou suas controladas não possuem processos sigilosos relevantes em } \\
\text { que sejam parte. }\end{array}$ \\
\hline $\begin{array}{l}\text { OMEGA GERAÇÃO } \\
\text { S.A. }\end{array}$ & $01 / 11 / 2018$ & $\begin{array}{l}\text { Estava em curso uma arbitragem sigilosa em que duas controladas da Companhia figuravam como partes. O valor discutido } \\
\text { referia-se à confirmação de multa aplicada pelas controladas junto a fornecedor de equipamentos no montante estimado atualizado } \\
\text { de } \mathrm{R} \$ 18,06 \text { milhões, decorrente de atrasos em fornecimento que geraram prejuízos à época do fornecimento. O fornecedor, por } \\
\text { sua vez, pleiteava o montante estimado atualizado de } \mathrm{R} \$ 37,23 \text { milhões, relativo a fornecimentos realizados no âmbito do contrato, } \\
\text { cujos pagamentos estavam retidos durante o curso da arbitragem, acrescido de valores relativos a supostos fornecimentos } \\
\text { adicionais não integrantes dos contratos e não reconhecidos pelas controladas. Em } 11 \text { de janeiro de } 2018 \text {, foi proferida sentença } \\
\text { arbitral que julgou parcialmente procedente o pedido do fornecedor para o recebimento dos valores em aberto do contrato no } \\
\text { montante histórico de } \mathrm{R} \$ 7.862 .656,26 \text {, corrigidos pelo CDI e acrescidos de multa de } 2 \% \text {. Conforme indicado nas últimas } \\
\text { Demonstrações Financeiras, o valor da contingência foi provisionado pela Companhia e será pago tempestivamente. }\end{array}$ \\
\hline OSX BRASIL S.A. & $04 / 12 / 2018$ & Não há processos sigilosos dos quais a Companhia e /ou suas controladas sejam partes em andamento. \\
\hline $\begin{array}{l}\text { OURO FINO SAUDE } \\
\text { ANIMAL } \\
\text { PARTICIPACOES S.A. }\end{array}$ & $31 / 10 / 2018$ & elevantes em que nós sejamos parte. \\
\hline
\end{tabular}


PARANAPANEMA S.A.

$03 / 01 / 2019$

(1) Somos parte em um Procedimento Arbitral no 02/2015 em que se discute um Instrumento Particular de Troca de Parâmetro (Swap), conforme já anteriormente informado no item 4.3. Procedimento Arbitral Único. a. juízo: Centro de Arbitragem e Mediação da Câmara de Comércio Brasil Canadá- CCBC. b. instância: Única. c. Data de instauração: 16.01.2015. d. partes no processo: Paranapanema S.A. X Banco Santander (Brasil) S.A. e Banco BTG Pactual S.A. e. valores, bens ou direitos envolvidos: \$700,4milhões (Valor corrigido até 3/12/2017).f. principais fatos: Em 12.01.2015, o Santander apresentou pedido de instauração de arbitragem contra a Paranapanema S.A e o BTG Pactual S.A, perante o Centro de Arbitragem e Mediação da Câmara de Comércio Brasil Canadá-CCBC ("CAM/CCBC"), em que pretendia discutir a validade de determinada obrigação e a existência de crédito contra a Paranapanema S.A., decorrentes do Contrato de Abertura de Crédito e dos instrumentos particulares de troca de parâmetros (Contratos de Swap) firmados entre as Partes, com a condenação da Companhia a pagá-lo. Trata-se de renovação do pleito originalmente formulado pelo Banco Santander S.A no (ii) procedimento arbitral n 17/2010 (“1ª Arbitragem”), também administrado pelo CAM/CCBC, cuja sentença arbitral foi objeto de ação anulatória proposta pela Companhia. Referida ação anulatória foi julgada parcialmente procedente em primeiro e segundo graus, sob o fundamento de vício na formação do painel arbitral da $1^{\mathrm{a}}$ Arbitragem, havendo recursos interpostos pela Companhia e pelo Banco BTG Pactual S.A. aos tribunais superiores (Processo $\mathrm{n}^{\circ}$ 0002163-90.2013.8.26.0100-TJSP). g. chance de perda: Possível. h. análise do impacto em caso de perda do processo: Impacto financeiro de R \$700,4 milhões (Valor corrigido até 31/12/2017). (2) Processo n. 0000900-17.2001.8.05.0039. a. juízo: $1^{\mathrm{a}}$ Vara Cível de Camaçari-BA. b. instância: $1^{\mathrm{a}}$ instância. c. data de instauração: 14.05.2001. d. partes no processo: Bafértil - Bahia Fertilizantes Ltda. x Cibrafértil -Companhia Brasileira de fertilizantes e Caraíba Metais S.A. e. valores, bens ou direitos envolvidos: $\mathrm{R} \$ 136,6$ milhões (Valor corrigido até 31/12/2017).

PDG REALTY S.A. EMPREEND E PARTICIPACOES

PETROBRAS DISTRIBUIDORA S/A

06/11/2018 Não Aplicável.

Em 31 de dezembro de 2017, a Companhia é parte no seguinte processo sigiloso relevante: Processo Arbitral, a. Análise do impacto em caso de perda do processo: O impacto financeiro corresponde aos valores informados no item "b" imediatamente abaixo, b. Valores envolvidos no processo: $\mathrm{R} \$ 708.018 .032,78 \mathrm{em} \mathrm{31/12/2017.}$

Em 31 de dezembro de 2017, a Companhia e/ou suas subsidiárias estavam no polo passivo em dois processos judiciais sigilosos, envolvendo um valor aproximado de $\mathrm{R} \$ 60.464 .059,69$ (sessenta milhões, quatrocentos e sessenta e quatro mil cinquenta e nove reais e sessenta e nove centavos). A Companhia e/ou suas subsidiárias contestam a integralidade do valor dessas ações. Parte deste valor possui provisão contábil constituída ainda que a Companhia, com base nos pareceres dos advogados que patrocinam as ações, considere as perdas como possíveis. 
POMIFRUTAS S/A

$12 / 11 / 2018$

\begin{tabular}{ll} 
PORTO SEGURO S.A. & $02 / 08 / 2018$ \\
\hline PBG S/A & $08 / 11 / 2018$ \\
POSITIVO & $09 / 01 / 2019$ \\
TECNOLOGIA S.A. & \\
PROFARMA DISTRIB & \\
PROD & $12 / 12 / 2018$
\end{tabular}

FARMACEUTICOS S.A.
Em relação aos processos sigilosos relevantes em que o emissor ou suas controladas sejam parte e que não tenham sido divulgados nos itens 4.3 e 4.4 acima, analisar o impacto em caso de perda e informar os valores envolvidos: (1) Arbitragem instaurada na Câmara de Arbitragem do Mercado (CAM) na data de 30/10/2015. Trata-se de processo arbitral movido pela Companhia contra Setentrium Participações Ltda., Érica Frey Caldart, Ruy Caldart, Aldani da Rocha Frey, César Arnoldo Frey, Cíntia Frey, Mara Caldart, Sandra Caldart da Rocha, Kátia Caldart Vescovi, Pomifrai Fruticultura S.A. e EFC Participações S.A., no qual, como comentado na nota explicativa $\mathrm{n}^{\circ} 18$, a Companhia pleiteia: (i) a invalidade de condição contratual contida no Acordo de Incorporação celebrado entre as partes em 02.12.2009, segundo a qual a Companhia estava obrigada a garantir, sob certas condições, cotação mínima para as ações entregues aos então acionistas da Pomifrai em virtude da operação de incorporação de ações, bem como (ii) a restituição à Companhia dos valores pagos a tais acionistas em conexão com essa previsão contratual ( $\mathrm{R} \$ 6,884$ milhões, em valores históricos). A Companhia estima que o seu benefício econômico em caso de êxito na arbitragem corresponderá a aproximadamente $\mathrm{R} \$ 25$ milhões. Os riscos da Companhia em caso de insucesso na arbitragem estão limitados ao pagamento das despesas administrativas com a arbitragem e de honorários advocatícios. (2) Arbitragem instaurada na Câmara de Arbitragem do Mercado (CAM) na data de 18/12/2015. Trata-se de processo arbitral movido contra antigos acionistas controladores e administradores, no qual a Companhia pleiteia: (i) o reconhecimento da eficácia da reconsideração, deliberada na Assembleia Geral Extraordinária realizada em 11/12/2015, (i.a) da aprovação das contas da antiga administração da Pomifrutas relativamente aos exercícios de 2013 e 2014, assim como (i.b) da quitação outorgada aos administradores em tais exercícios (ou, sucessivamente, a anulação de tais aprovações de contas e outorgas de quitação); (ii) a declaração da invalidade da aprovação pelo conselho de administração da Companhia das contas da antiga administração da Companhia relativamente aos primeiros trimestres de 2015, assim como de quitação outorgada pelo referido conselho a membros da antiga administração; (iii) a declaração da invalidade de contratos de prestação de serviço de consultoria financeira celebrados pela Companhia com as sociedades RB, Private e Valor, com a condenação de tais sociedades, em solidariedade com os demais Requeridos, a indenizarem a Pomifrutas pelas perdas e danos sofridos em decorrência dos mencionados contratos; e (iv) a condenação dos antigos controladores e membros da administração da Companhia, respectivamente, por abuso de poder de controle e desrespeito a deveres fiduciários, com a sua condenação a indenizar a Pomifrutas pelas perdas e danos sofridos em razão dos atos irregulares praticados. A Companhia estima que o seu benefício econômico em caso de êxito na arbitragem é potencialmente relevante. Os riscos da Companhia em caso de insucesso na arbitragem estão limitados ao pagamento das despesas administrativas com a arbitragem e de honorários advocatícios.

A Companhia e suas controladas não possuem processos sigilosos relevantes.

Não se aplica, tendo em vista que a Companhia e suas controladas não são partes de processos sigilosos relevantes.

Em 31 de dezembro de 2017, a Companhia e suas controladas não possuíam processos sigilosos em que a Companhia ou suas controladas fossem parte.

Em 31 de dezembro de 2017, a nossa Companhia e/ou nossas controladas não eram partes em qualquer processo sigiloso relevante. 


\begin{tabular}{|c|c|c|}
\hline $\begin{array}{l}\text { QGEP PARTICIPAÇÕES } \\
\text { S.A. }\end{array}$ & 03/01/2019 & $\begin{array}{l}\text { Tendo em vista a inadimplência histórica da Dommo Energia S.A. (denominada "Dommo", antiga OGX Petróleo e Gás S.A. - } \\
\text { Recuperação Judicial) com suas obrigações de aporte financeiro no consórcio do Bloco BS-4, a Barra Energia exerceu em outubro } \\
\text { de } 2017 \text { os direitos de expulsão previstos nos documentos do consórcio. A Dommo contesta a validade da expulsão em } \\
\text { procedimento arbitral perante a Corte de Arbitragem Internacional de Londres (LCIA) no qual a nossa controlada QGEP } \\
\text { atualmente figura como parte passiva. Não é possível avaliar seus impactos, tendo em vista o status atual em que o processo se } \\
\text { encontra. Todavia, nesta data, nossos advogados entendem como remota as chances de perda pela QGEP do processo. }\end{array}$ \\
\hline $\begin{array}{l}\text { QUALICORP } \\
\text { CONSULTORIA E } \\
\text { CORRETORA DE } \\
\text { SEGUROS S.A. }\end{array}$ & $11 / 12 / 2018$ & Até a data deste Formulário de Referência, não há processos sigilosos relevantes em que nós sejamos parte \\
\hline RAIA DROGASIL S.A. & 28/11/2018 & $\begin{array}{l}\text { Não existem informações adicionais sobre processos sigilosos relevantes dos quais somos parte e não foram divulgados nos itens } \\
4.3 \text { e } 4.4 \text {. }\end{array}$ \\
\hline $\begin{array}{l}\text { RNI NEGÓCIOS } \\
\text { IMOBILIÁRIOS S.A. }\end{array}$ & 24/04/2018 & Não aplicável, tendo em vista que não há processos sigilosos relevantes em que a Companhia ou suas controladas são parte. \\
\hline $\begin{array}{l}\text { ROSSI RESIDENCIAL } \\
\text { S.A. }\end{array}$ & $13 / 12 / 2018$ & anhia e suas investidas não são parte em processos sigilosos relevantes. \\
\hline
\end{tabular}


RUMO S.A.

$05 / 11 / 2018$

(1) Rumo Malha Norte, Rumo Malha Sul, Rumo Malha Paulista e a Rumo S/A eram partes em um procedimento arbitral confidencial cujo valor total dos pedidos somava a quantia de $\mathrm{R} \$ 305,2$ milhões. Foi prolatada sentença arbitral e, após liquidação de sentença arbitral, no segundo trimestre de 2017, apurou-se ser devido pela Companhia R\$ 114 milhões, que foram devidamente pagos. Apesar de pagos os valores, a parte adversa entendeu que houve pagamento a destempo e iniciou cumprimento de sentença para exigir multa pelo cumprimento a supostamente realizado destempo. Rumo apresentou impugnação ao cumprimento de sentença, a qual foi rejeitada, tendo sido interposto Agravo de Instrumento, o qual teve efeito suspensivo concedido. Aguarda-se o julgamento do Agravo de Instrumento Interposto por Rumo. (2) Além disso, a Rumo S.A. ("Rumo") é parte em procedimento arbitral confidencial a respeito de um acordo de acionistas de uma de suas subsidiárias relevantes. O valor envolvido neste procedimento pode representar um dispêndio significativo para a Companhia, estimado pela parte contrária em R $\$ 544 \mathrm{milhões.}$ A determinação do valor efetivamente envolvido na arbitragem ("Montante Envolvido") depende de eventual produção probatória, ainda não iniciada, tendo em vista que se aguarda decisão do Tribunal Arbitral a respeito dos argumentos da Rumo referentes à desnecessidade de produção de novas provas face aos documentos já apresentados. Os possíveis desfechos do procedimento para a Rumo são: (i) a condenação da Rumo ao pagamento, em moeda corrente, de montante correspondente a até o Montante Envolvido; ou (ii) a emissão de novas ações da Rumo em quantidade correspondente a até o Montante Envolvido, o que poderá diluir a participação dos acionistas da Rumo em seu capital social. A Companhia estima o risco de pagamento em pecúnia como remoto e o pagamento em ações como possível. Em 31/12/2017 aguardava-se designação de audiência de instrução.

(3) Em adição, a Rumo Malha Norte, Rumo Malha Sul, Rumo Malha Paulista e a Rumo S/A são partes em procedimento arbitral confidencial, cujo valor total dos pedidos soma a quantia de $\mathrm{R} \$ 430$ milhões. O procedimento foi instaurado pela parte contrária sob a alegação de que Rumo teria dado causa à rescisão de contrato de serviço transporte ferroviário e investimentos, diante do que requereu indenização. A Rumo apresentou reconvenção, na qual pretende seja reconhecida a improcedência dos pleitos da parte contrária, bem como a responsabilidade da parte contrária em arcar com as perdas e danos decorrentes de sua rescisão imotivada. As partes apresentaram requerimento e resposta/reconvenção. O painel arbitral já foi formado. Em 31/12/2017 aguardava-se apresentação das alegações iniciais. (4) Em 2010, a Prumo Engenharia Ltda. ("Prumo Engenharia"), empresa prestadora de serviço da então ALL -América Latina Logística SA ("ALL"), foi acusada de incorrer em práticas trabalhistas irregulares durante a execução de serviço de engenharia para uma subsidiária da ALL. Independentemente e sem prejuízo de sua defesa e da alegação de que não houve práticas trabalhistas irregulares, a Prumo Engenharia já reconheceu e assumiu responsabilidade integral pela condição dos trabalhadores em questão, inclusive perante a Superintendência Regional do Trabalho, isentando a ALL de toda e qualquer responsabilidade. Entretanto, a Rumo Malha Paulista S.A. ('Malha Paulista"), subsidiária da Rumo S.A., nova denominação da sociedade então subsidiária da ALL que contratou o serviço da Prumo Engenharia em 2010, foi incluída indevidamente, na visão da Companhia, no cadastro de empregadores do Ministério do Trabalho por referidas práticas de responsabilidade da Prumo Engenharia. Os fatos em questão estão em discussão no Poder Judiciário e no Ministério do Trabalho

CIA SANEAMENTO

BASICO EST SAO

$28 / 12 / 2018$

Não existem processos sigilosos relevantes em que a Companhia e suas controladas sejam partes e que não tenham sido divulgados nos itens 4.3 e 4.4 acima. 
SANTOS BRASIL PARTICIPACOES S.A.

$21 / 12 / 2018$

(1) Processo $n^{\circ} 00099762020154036100$, Valores, bens ou direitos envolvidos: Autorização de alfandegamento concedida à SBPAr no Tecon Santos, Análise do impacto: Chances remotas de insucesso na ação ordinária proposta pela Companhia, havendo alta probabilidade deque a antecipação de tutela já deferida em favor da SBPar, suspendendo os efeitos da decisão proferida em processo administrativo, seja mantida até a decisão definitiva da lide, Provisão: Não há; (2) Processo nº 00153051320154036100, Valores, bens ou direitos envolvidos: Autorização de alfandegamento concedida à SBPAr no Tecon Santos, Análise do impacto: Chances remotas de insucesso na ação ordinária proposta pela Companhia, havendo alta probabilidade de que a antecipação de tutela já deferida em favor da SBPar, suspendendo os efeitos da decisão proferida em processo administrativo, seja mantida até a decisão definitiva da lide, Provisão: Não há.

$\begin{array}{ll}\text { SAO CARLOS } & \\ \text { EMPREEND E } & 06 / 11 / 2018 \\ \text { PARTICIPACOES S.A. } & \\ \text { SAO MARTINHO S.A. } & 19 / 11 / 2018 \\ \text { SENIOR SOLUTION } & 17 / 12 / 2018 \\ \text { S.A. } & \\ \text { SER EDUCACIONAL } & 31 / 10 / 2018 \\ \text { S.A. } & \\ \text { SONAE SIERRA } & \end{array}$

SONAE SIERRA $\quad 07 / 11 / 2018$

BRASIL S.A. $11 / 2018$

SLC AGRICOLA S.A.

$23 / 07 / 2018$

SMILES FIDELIDADE

S.A.

$10 / 12 / 2018$

SOMOS EDUCAÇÃO

S.A.

04/01/2019

SPRINGS GLOBAL

PARTICIPACOES S.A.

SUZANO PAPEL E

CELULOSE S.A.

TARPON

INVESTIMENTOS S.A.

13/11/2018 O emissor não possui processos sigilosos.

19/10/2018 A Companhia e suas controladas não são parte em processos sigilosos relevantes.

TECHNOS S.A.

$10 / 01 / 2019$

A Companhia não possui processos sigilosos relevantes.

$09 / 11 / 2018$

Na data deste Formulário de Referência, não há qualquer processo sigiloso relevante no qual a Companhia ou suas controladas sejam parte e que não tenha sido divulgado nos itens 4.3 e 4.4 deste Formulário de Referência.

TECNISA S.A. $06 / 11 / 2018$

TEGMA GESTAO

LOGISTICA S.A.

$29 / 11 / 2018$
Não aplicável, tendo em vista que não há processos sigilosos relevantes em que a Companhia ou suas controladas sejam parte. Não há processos sigilosos relevantes em que a Companhia ou suas controladas sejam parte e que não foram divulgados nos itens 4.3 e 4.4 acima. 


\section{CONSTRUTORA}

TENDA S.A.

$18 / 12 / 2018$

\section{TERRA SANTA AGRO}

$$
\text { S.A. }
$$

TIM PARTICIPACOES

S.A.

T4F

ENTRETENIMENTO

\section{S.A.}

TOTVS S.A.

TRISUL S.A

TPI - TRIUNFO

PARTICIP. E INVEST

S.A.

TUPY S.A.

ULTRAPAR

PARTICIPACOES S.A.

UNICASA INDÚSTRIA

DE MÓVEIS S.A.

\section{$30 / 11 / 2018$}

10/01/2019
Até a data base deste Formulário de Referência, a Companhia possuía os seguintes processos sigilosos relevantes: (1) Procedimento Arbitral - Companhia - Processo no 34/2015/SEC, Valores, bens ou direitos envolvidos: A Companhia é autora em uma arbitragem que versa sobre inadimplemento do contrato de construção com pedidos indenizatórios formulados pela Companhia em face da parte adversária. Análise do impacto em caso de perda do processo: Não recebimento dos valores pleiteados. Chance de perda Possível; (2) Procedimento Arbitral - Companhia - Processo no 12/11 - CAMARB/MG. Valores, bens ou direitos envolvidos: A Companhia é autora e ré em uma arbitragem que versa sobre inadimplemento do contrato de construção com pedidos indenizatórios formulados reciprocamente, tendo sido proferida sentença onde ambas as partes foram condenadas, devendo os valores serem apurados em posterior liquidação. Análise do impacto em caso de perda do processo: Pagamento dos valores pleiteados. Chance de perda: Provável; (3) Procedimento Arbitral - Companhia - Processo $\mathrm{n}^{\circ}$ 33/2013/SEC-1 -CCBC/SP, Valores, bens ou direitos envolvidos: A Companhia é autora e ré em uma arbitragem que versa sobre litígios entre sócios com pedidos indenizatórios formulados reciprocamente, Análise do impacto em caso de perda do processo: Pagamento dos valores pleiteados, Chance de perda: Possível; (4) Procedimento Arbitral - Companhia - Processo $\mathrm{n}^{\circ}$ 05/2014/SEC3 -CCBC/SP, Valores, bens ou direitos envolvidos: A Companhia é autora e ré em uma arbitragem que versa sobre litígios entre sócios, tendo sido proferida sentença onde ambas as partes foram condenadas, devendo os valores serem apurados em posterior liquidação, Análise do impacto em caso de perda do processo: Pagamento dos valores pleiteados, Chance de perda: Provável; (4) Procedimento Arbitral - Companhia - Processo no 22/2009 -CCBC/SP, Valores, bens ou direitos envolvidos: A Companhia é autora em uma arbitragem que versa sobre inadimplementos contratuais, Análise do impacto em caso de perda do processo: Não recebimento dos valores pleiteados, Chance de perda: Possível.

20/12/2018 A Companhia não possui nenhum processo sigiloso em andamento.

Considerando a atual fase processual, não é possível informar de forma de acurada o valor de risco envolvido na demanda. Todavia, foi apresentada a quantia de $\mathrm{R} \$ 1.000 .000,00$, a título de valor da causa, para fins de recolhimento de custas. A TIM requer em seus pedidos reconvencionais a quantia de $\mathrm{R} \$ 3.000 .000,00$. Análise do possível impacto para o emissor ou suas controladas, em caso de perda: Impacto econômico e financeiro, em valores que ainda não podem ser estimados pela Companhia, de forma acurada.

26/11/2018 Na data deste Formulário de Referência não há processos sigilosos relevantes em que nós ou nossas controladas sejamos parte.

02/01/2019 A Companhia não está envolvida em processos sigilosos relevantes.

13/12/2018 Até 30/12/2017, não há processos sigilosos relevantes em que a Companhia ou suas controladas sejam parte.

25/10/2018 Não aplicável.

21/12/2018 Não aplicável. 26/10/2018 Não existem outros processos sigilosos relevantes em que a Companhia ou suas controladas sejam parte e que não tenham sido
divulgados nos itens 4.3 e 4.4 acima. 


\begin{tabular}{|c|c|c|}
\hline VALE S.A. & 07/01/2019 & $\begin{array}{l}\text { Processo n }{ }^{\circ} \text { 0393909-98.2012.8.19.0001, Valores, bens ou direitos envolvidos: Valor envolvido no processo conforme análise da } \\
\text { Companhia em } 31 \text { de dezembro de } 2017 \text { : R } \$ 119 \text { milhões. Discussão quanto às condições de vencimento de debêntures } \\
\text { específicas. Processo julgado procedente, em desfavor dos interesses da Vale, tendo a decisão sido mantida em segunda instância. } \\
\text { Recurso às instâncias superiores ainda pendente de julgamento. Análise do impacto em caso de perda: Eventual decisão } \\
\text { desfavorável no processo geraria para a Companhia prejuízos financeiros. }\end{array}$ \\
\hline VALID SOLUÇÕES S.A. & $21 / 12 / 2018$ & Não há processos sigilosos relevantes a serem divulgados. \\
\hline VIA VAREJO S.A. & 02/01/2019 & $\begin{array}{l}\text { Na data de apresentação deste Formulário de Referência, a Companhia ou suas controladas não apresentaram processos judiciais } \\
\text { que sejam considerados relevantes. }\end{array}$ \\
\hline $\begin{array}{l}\text { VIVER } \\
\text { INCORPORADORA E } \\
\text { CONSTRUTORA S.A. }\end{array}$ & 04/01/2019 & $\begin{array}{l}\text { A Companhia e suas controladas não possuem processos sigilosos relevantes em que a Companhia ou suas controladas sejam } \\
\text { parte e que não tenham sido divulgados nos itens anteriores. }\end{array}$ \\
\hline $\begin{array}{l}\text { VULCABRAS/AZALEIA } \\
\text { S.A. }\end{array}$ & $21 / 12 / 2018$ & $\begin{array}{l}\text { Até a data deste formulário de referência, a Companhia e suas controladas não era parte de nenhum processo sigiloso. Todos os } \\
\text { processos relevantes foram descritos na seção } 4.3 \text {. }\end{array}$ \\
\hline WEG S.A. & $21 / 12 / 2018$ & Não existem processos sigilosos relevantes a discutir. \\
\hline $\begin{array}{l}\text { WIZ SOLUÇÕES E } \\
\text { CORRETAGEM DE } \\
\text { SEGUROS S.A. }\end{array}$ & $18 / 12 / 2018$ & em processos sigilosos relevantes. \\
\hline
\end{tabular}

